UNIVERSIDADE DE BRASÍLIA - UnB

INSTITUTO DE LETRAS - IL

DEPARTAMENTO DE LÍNGUAS ESTRANGEIRAS E TRADUÇÃO - LET PROGRAMA DE PÓS-GRADUAÇÃO EM ESTUDOS DA TRADUÇÃO POSTRAD

\title{
A FALA EM LINHAS: AUSÊNCIA E PRESENÇA DAS MARCAS DE ORALIDADE NA TRADUÇÃO DE THE SHINING
}

NATHÁLIA LOUISE CORVELLO FILGUEIRAS

DISSERTAÇÃO DE MESTRADO EM ESTUDOS DA TRADUÇÃO

BRASÍLIA - DF

MARÇO, 2016 
UNIVERSIDADE DE BRASÍLIA - UnB INSTITUTO DE LETRAS - IL

DEPARTAMENTO DE LÍNGUAS ESTRANGEIRAS E TRADUÇÃO - LET

PROGRAMA DE PÓS-GRADUAÇÃO EM ESTUDOS DA TRADUÇẪO - POSTRAD

A FALA EM LINHAS: AUSÊNCIA E PRESENÇAS DAS MARCAS DE ORALIDADE NA TRADUÇÃO DE THE SHINING

NATHÁLIA LOUISE CORVELLO FILGUEIRAS

ORIENTADOR: JÚLIO CÉSAR NEVES MONTEIRO

DISSERTAÇÃO DE MESTRADO EM ESTUDOS DA TRADUÇÃO

BRASÍLIA-DF

MARÇO, 2016 


\begin{abstract}
UNIVERSIDADE DE BRASÍLIA
INSTITUTO DE LETRAS - IL

DEPARTAMENTO DE LÍNGUAS ESTRANGEIRAS E TRADUÇÃO - LET

PROGRAMA DE PÓS-GRADUAÇÃO EM ESTUDOS DA TRADUÇÃ̃O - POSTRAD
\end{abstract}

\title{
A FALA EM LINHAS: AUSÊNCIA E PRESENÇA DAS MARCAS DE ORALIDADE NA TRADUÇÃO DE THE SHINING
}

\section{NATHÁLIA LOUISE CORVELLO FILGUEIRAS}

DISSERTAÇÃO DE MESTRADO SUBMETIDA AO PROGRAMA DE PÓS-GRADUAÇÃO EM ESTUDOS DA TRADUÇÃO, COMO PARTE DOS REQUISITOS NECESSÁRIOS À OBTENÇÃO DO GRAU DE MESTRE EM ESTUDOS DA TRADUÇÃO.

APROVADA POR:

Prof. Dr. JÚLIO CÉSAR NEVES MONTEIRO, (Universidade de Brasília) (ORIENTADOR)

Prof $^{a}$. Dr ${ }^{\mathrm{a}}$. ALESSANDRA DE OLIVEIRA HARDEN, (Universidade de Brasília) (EXAMINADOR INTERNO)

Prof $^{a} \operatorname{Dr}^{\mathrm{a}}$. Luana Ferreira de Freitas, (Universidade Federal do Ceará) (EXAMINADOR EXTERNO)

Brasília - DF, 31 de março de 2016 
À Deborah Cristina Guedes dos Reis e à Maria Stefânia, responsáveis pela iluminação e inspiração deste trabalho. 


\section{AGRADECIMENTOS}

Ao orientador Júlio César Neves Monteiro:

Pelo apoio e pela dedicação para com a construção deste trabalho.

À agência de fomento Capes:

Pela bolsa concedida para a realização desta dissertação.

Aos familiares e amigos:

Pelo incentivo para a conclusão do mestrado e pela paciência durante a escrita da dissertação. 


\section{RESUMO}

O romance The Shining, de Stephen King, retrata os acontecimentos insólitos vividos pela família Torrance num hotel isolado nas montanhas do Colorado, EUA. A história de horror logo conquistou o público e tornou-se um bestseller, em especial após a adaptação para o cinema, com direção de Stanley Kubrick. Traduzida para o português brasileiro no mesmo ano de sua publicação nos Estados Unidos, a obra literária ganhou novas edições no Brasil desde então, embora mantendo a primeira tradução (Albuquerque, 1977) praticamente inalterada. Uma das características literárias The Shining é a presença de marcas de oralidade - um recurso literário que pretende simular a língua falada na escrita -, o que lhe confere um tom de informalidade e traz nuanças relacionadas à origem e faixa etária dos personagens, por exemplo. Todavia, as marcas de oralidade foram omitidas na tradução brasileira. Tal fato não constitui, por si só, uma desvantagem do texto traduzido em relação ao texto de partida, mas apresenta um leque de possibilidades que poderiam explicar a escolha pelo apagamento das marcas. Entre essas possibilidades, estão, por exemplo, as normas da editora, que desaconselhariam a utilização de um registro informal, talvez para se adequar às práticas do sistema literário em que a tradução se insere. Neste trabalho, investigarei os motivos que explicam as escolhas tradutórias de Albuquerque e as consequências sofridas na tradução por uma estratégia de neutralizar a oralidade na narrativa. Além disso, analisarei as mudanças relativas à oralidade feitas em uma revisão feita décadas após a primeira publicação da tradução e realizarei uma comparação crítica entre a tradução publicada e uma proposta de tradução realizada por alunas de graduação da Universidade de Brasília, com o objetivo de representar traços da língua falada em português brasileiro, identificando as vantagens e desvantagens referentes à tentativa de tradução de tal recurso literário.

Palavras-chave: O iluminado, tradução literária, marcas de oralidade, comparação crítica 


\begin{abstract}
The novel The Shining by Stephen King, portrays the unusual events experienced by the Torrance family in a secluded hotel in the mountains of Colorado, USA. The horror story soon conquered the public and became a bestseller, especially after the film adaptation, directed by Stanley Kubrick. Translated to Brazilian Portuguese in the same year it was published in the United States, the literary work gained new editions in Brazil since then, while maintaining the first translation (ALBUQUERQUE, 1977) virtually unchanged for many years. One of the literary features The Shining is the presence of orality marks - a literary resource which simulates the spoken language in writing - which gives narrative an informal tone and brings nuances regarding the origin and age of the characters, for example. However, orality marks have been omitted in the Brazilian translation. This fact is not, by itself, a disadvantage of the translated text in relation to the original text, but offers a range of possibilities that could explain the choice of omitting such a literary resource. Among these possibilities are, for example, the rules of the publisher, which may recommend the use of an informal register, perhaps to suit the literary system of practices in which the translation is inserted. In this work, I will investigate the reasons that explain the translational choices of Albuquerque and the consequences suffered in translation by a strategy which neutralizes the orality in the narrative. Also, I examine the changes regarding orality made in the translation reviewed decades after its first publication, and I work a critical comparison between the published translation and a proposal of translation written by undergraduate students at the University of Brasilia, in order to represent features of spoken language in Brazilian Portuguese, identifying the advantages and disadvantages of such translation.
\end{abstract}

Key-words: The Shining, literary translation, orality marks, crtical comparison. 


\section{LISTA DE TABELAS}

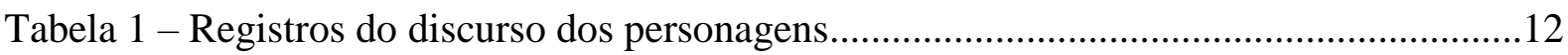

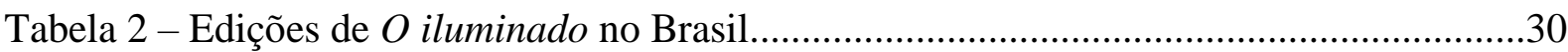

Tabela 3 - Comparação dos trocadilhos que Danny faz com as palavras................................38

Tabela 4 - Marcas de oralidade em mistura de pessoa-número.............................................60

Tabela 5 - Marcas de oralidade em uso do pronome reto no lugar do pronome oblíquo.........61

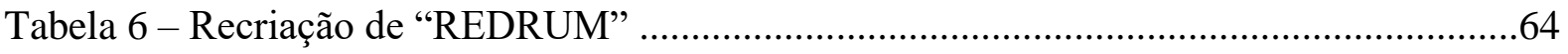




\section{SUMÁRIO}

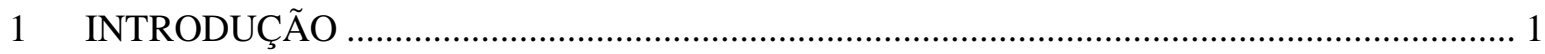

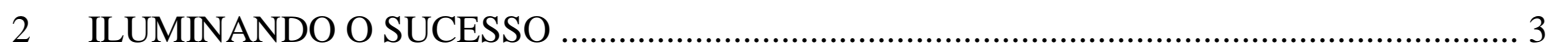

2.1 Sobre um bestseller de horror: a história, a publicação, o autor................................................ 3

2.2 Aterrorizando em solo brasileiro: a recepção do texto traduzido no Brasil ................................ 4

2.3 Arrepios na narrativa: características marcantes e construção dos personagens ......................... 6

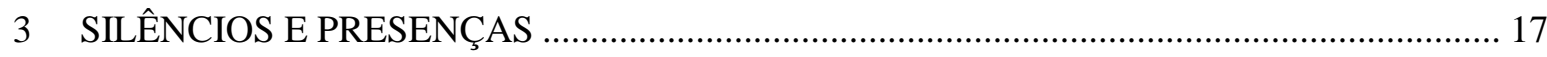

3.1 Outro contexto, outra história: sob a luz da Teoria dos Polissistemas ................................... 17

3.2 Outra língua, outros sustos: recursos literários recriados na tradução de The Shining ............ 26

3.3 Outros tempos, outra dimensão: a presença no sistema literário brasileiro atual .................... 40

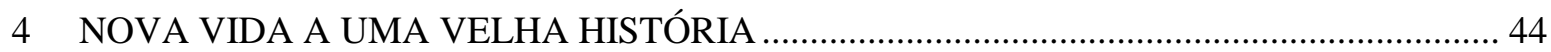

4.1 Recriando o horror: rumo a uma tradução com sussurros, vozes e gritos ................................ 44

4.2 “E se?”: a proposta de uma nova estratégia de tradução para a obra ........................................ 53

4.3 Limites e possibilidades: será possível a renovação da tradução? ............................................ 67

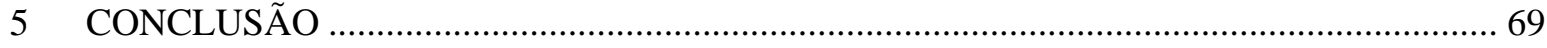

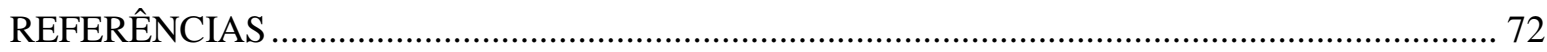

ANEXO I - EXCERTO DA TRADUÇÃO DE THE SHINING ............................................................ 75 


\section{INTRODUÇÃO}

No segundo semestre de 2011, na Universidade de Brasília, as alunas Débora Cristina Guedes dos Reis, Maria Stefânia Caldeira Henrique e Nathália Louise Corvello Filgueiras reuniam-se para elaborar o projeto final do curso de graduação em Letras - Tradução - Inglês. Assim surgiu "Traduzindo The Shining: uma realidade assustadora..." (2011), uma proposta de retradução de trechos selecionados da obra The Shining, de Stephen King (1977). Nesse projeto, as autoras relataram em detalhes todo o processo de tradução, inclusive produzindo um glossário de termos da narrativa, bem como as justificativas para uma nova tradução. Queriam dar nova vida ao texto, ressaltando o efeito de terror, o qual julgavam empobrecido na versão publicada no Brasil.

Anos depois, eu, a Nathália (autora da presente dissertação), já aluna do Mestrado em Estudos da Tradução, decidi resgatar o referido trabalho de graduação e lançar um novo olhar para um dos assuntos que ele abordava: a oralidade na tradução. Enquanto em 2011 eu e as outras duas autoras tratamos da oralidade com base em nossa própria proposta de tradução, aqui lanço outro desafio: verificar como uma total ausência de traços da língua falada brasileira na tradução feita por Betty Ramos de Albuquerque (1977) evoluiu para uma revisão em (2009) permeada, ainda que discretamente, por formas características da expressão oral, em especial nos diálogos.

Diante dessa mudança nas edições, questiono-me se a citada proposta de retradução já não estaria indicando o rumo pelo qual as futuras revisões (se existirem) tendem a seguir. Um caminho de estratégias de tradução mais criativas, que reescrevam a oralidade notada no texto de partida. Assim, passo a analisar as vantagens de se adotar uma tradução criativa, como fizemos no projeto final, e os obstáculos que essa maneira de traduzir teria de enfrentar para ser aceita pelo público ledor brasileiro.

Portanto, para formular minhas conclusões, atravessarei algumas etapas: em "Iluminando o sucesso", contarei a história de The Shining e mostrarei o contexto de seu lançamento, a adaptação para a sétima arte, a vinda para o mercado editorial brasileiro, as suas traduções e a sua recepção. Também serão destacadas as características desse romance que considero as mais relevantes do ponto de vista literário. Farei um resumo sobre a obra e seu contexto de lançamento, analisarei a recepção da obra e da tradução e discutirei os aspectos literários que mais se destacam na obra. Para tanto, embasar-me-ei principalmente nos teóricos 
seguintes: Britto (2012), Todorov (1992) e Kohan (2013), mas complementando a discussão com outros.

Num segundo momento, darei ouvido ao capítulo "Silêncios e presenças", em que iniciarei discorrendo a respeito dos motivos que (podem) explicar as mudanças ocorridas no sistema literário de uma sociedade que permitem alterações na tradução, bem como na aceitação ou rejeição de um texto por parte do público. Para tal, estarei amparada, em especial, na Teoria dos Polissistemas (EVEN-ZOHAR, 1990). Em seguida, analisarei como os recursos literários discutidos no capítulo anterior foram traduzidos na primeira versão em português brasileiro de The Shining no Brasil. Para concluir o capítulo, demonstrarei as mudanças realizadas na revisão de 2009, que permaneceram, vale mencionar, na edição subsequente (2012). A fim de compreender os meandros das mudanças na tradução e a aceitação do público, além de EvenZohar, trarei para a discussão a abordagem das normas na tradução, segundo Toury (1995), e autores como Bloom (1993), Silva (2007), Barrento (2014), entre outros.

O último capítulo, "Nova vida a uma velha história", tratará da possibilidade de uma escrita que não se paute tão somente pela gramática normativa para as soluções tradutórias, mas que busque recriar recursos e efeitos do texto fonte de modo mais criativo e menos formal. Ou seja, traduções criativas que recriem ativamente efeitos e recursos literários do original, modificando, se necessário, a estrutura sintática e lexical que seria esperada de uma tradução muito literal ou, como no caso da tradução brasileira de The Shining, de uma que priorizasse tão somente a gramática normativa, o que acarretaria na supressão da oralidade na tradução, divergindo, portanto, do efeito natural e espontâneo verificado no texto fonte. Como exemplo, demonstrarei as estratégias adotadas pelas autoras da proposta de retradução (2011) da obra de King, ponderando as vantagens, os problemas e os riscos de tal modo de tradução do romance que tenha como estratégia a recriação das marcas de oralidade de modo ainda mais extensivo do que foi feito na revisão publicada. Os teóricos utilizados para dar suporte aos meus objetivos serão, no geral: Azevedo (1998), Britto (2012), Paes (1995), Berman (2002) - não esgotando, mais uma vez, o referencial apenas neles. 


\section{ILUMINANDO O SUCESSO}

\subsection{Sobre um bestseller de horror: a história, a publicação, o autor}

A história de terror vivida pela família Torrance, isolada num hotel encravado no meio das montanhas do Colorado, estado dos EUA, preenche as páginas de The Shining, romance de Stephen King. Ao longo da trama, o leitor é apresentado ao processo de enlouquecimento de Jack Torrance, o pai, o qual sucumbe a supostas influências sobrenaturais exercidas pelo hotel Outlook, em que atua como zelador. Seu filho, Danny, e sua esposa, Wendy, não passam incólumes perante os fatos inusitados que se sucedem durante a estadia no Outlook. Wendy, embora seja pouco afetada pela "maldade" do hotel, sofre ao perceber a mudança negativa no comportamento de seu marido, que está a cada dia mais agressivo e delirante, bem como no de seu filho, que demonstra cada dia mais estar em conexão com alguma realidade paralela, apresentando indícios de paranormalidade.

Após seu lançamento em 1977, nos Estados Unidos da América, The Shining destacase no mercado editorial e encontra ampla recepção de público. São publicadas traduções para inúmeras línguas (MCDOWELL, 1981) e uma adaptação cinematográfica produzida em 1980, com direção de Stanley Kubrick e Jack Nicholson como ator principal.

Nos EUA, o livro já foi publicado por diversas editoras, sendo a última edição em 2014. Talvez devido ao sucesso do filme, The Shining elevou-se ao status de ícone da cultura pop, sendo facilmente comercializados produtos com referência de cenas da versão de Kubrick. A obra para o cinema é referenciada em outros filmes e séries, encontrando considerável aceitação junto ao público contemporâneo.

Com efeito, o livro ainda gera interesse no público contemporâneo, conquistando novos leitores e assim gozando de relativa importância no mercado editorial estadunidense. Além disso, em ano mais recente foi lançada a continuação da história de King: em Dr. Sleep (2013), Danny Torrance agora é um adulto que tem de lidar com os dons sobrenaturais descobertos na infância e superar o trauma dos ocorridos no hotel Outlook. Acredito, portanto, que o prosseguimento da história renova o olhar e a percepção para com sua narrativa originária e suscita o interesse de novos leitores para ela. 


\subsection{Aterrorizando em solo brasileiro: a recepção do texto traduzido no Brasil}

No Brasil, a obra é logo lançada no mercado editorial: ainda em 1977, é publicada a sua primeira edição, pela editora Record, com tradução de Betty Ramos de Albuquerque, sob o título "O iluminado" (1977), com edições subsequentes pela editora Objetiva (1999, 2005 e 2009) e, por último, pela Suma de Letras, um selo da editora Objetiva, em 2012, todas com o mesmo texto da primeira tradutora. A existência das novas edições pode-se justificar pelo interesse do público na obra, que, tal como no país de origem, persevera, em especial entre os apreciadores dos gêneros fantástico e de horror. Ainda pode-se justificar o interesse em novas edições devido à publicação da continuação literária da obra, Dr. Sleep, já mencionada, que foi traduzida para o português brasileiro, em 2014, pelo tradutor Roberto Grey, e publicada pela editora Suma de Letras.

As edições brasileiras de The Shining não têm gerado interesse da crítica especializada em aspectos tradutórios, desde sua primeira versão. Em outras palavras, a aceitação do público voltou-se, até onde foi possível analisar, exclusivamente para a história apresentada, quase como se $O$ iluminado tivesse sido escrito em português pelo autor. O público, como verificado na seção de comentários nos sites de vendas de livros online, mostrados abaixo, igualmente ignora o fato de o texto ser uma tradução e se restringe a realizar observações acerca da trama, do autor etc., como se vê nos exemplos abaixo:

a) comentários retirados das avaliações dos leitores do website Saraiva:

Karina: Fantástico. Pra mim é o livro mais aterrorizante q já li...

Luiz: O melhor livro. Sem duvida o melhor livro de suspense e é um livro que eu recomendo para todas as pessoas.

Arthur Victor: Brilhante! Um dos melhores do Stephen King! (acesso em janeiro 2016)

b) comentários retirados das avaliações dos leitores do website Livraria Cultura:

Claudio Augusto: The Best book of terror. O iluminado li esse livro há 10 anos foi o meu primeiro do King Mestre do terror e suspense amei a leitura, já vi o filme do Diretor Stanley Kubrick de 1980 com Jack Nicholson. Agora vou 
comprar o livro com nova capa recomendo a todos que curtem um bom livro de suspense.

Gabriel Gonçalves Germano: Obra-prima. Um dos primeiros livros fenomenais de King, esse é um clássico e um dos melhores livros do autor.

Diego F. Lugato: Fundamental. Para aqueles que querem entender melhor o filme O Iluminado, a leitura do livro é essencial. Para aqueles que amam os novos clássicos, fundamental. De qualquer forma é diversão garantida. Vale cada centavo. (acesso janeiro 2016)

De modo semelhante, em consulta a um blog pessoal de literatura entre os dez primeiros resultados do site de buscas Google para a combinação de termos "o iluminado tradução", não há qualquer crítica à tradução: o blog "No mundo dos livros", contém uma postagem que se centra na resenha do livro, observações quanto aos temas e à estrutura narrativa, comentários sobre o autor, observações sobre a capa do livro, além de menções à adaptação cinematográfica (LIVY, 2013). Comentários acerca de problemas ou soluções da tradução inexistiam.

Em um ensaio que discorre a respeito do medo em $O$ iluminado (GONÇALVES, 2012) considerando aspectos literários, embora o autor utilize todos os exemplos em língua portuguesa, extraídos da tradução de Betty Ramos de Albuquerque, não se mencionou que o texto abordado tratava-se de uma tradução, tampouco foram encontradas observações de aspectos da tradução.

No entanto, admito que a expectativa de ler uma crítica da tradução de $O$ iluminado restringe-se a um público diminuto, do qual se pode citar tradutores, revisores, estudantes e pesquisadores de tradução. Dificilmente se encontram críticas de tradução advindas dos leitores, em especial se tratando de um texto não canônico, cujos leitores, em geral, não me parecem se importar com minúcias de tradução literária. Porém, como também não encontrei qualquer crítica ou trabalho acadêmico especializados em tradução acerca do assunto (exceto o de Filgueiras, Henrique e Reis (2011), optei por destacar os exemplos dos sites e blogs acima, que ignoram o fato de o texto ser uma tradução, para demonstrar que a aceitação dessa narrativa de King no Brasil é ampla e não se opõe ao texto como foi traduzido, seja nas edições anteriores ou posteriores à revisão mais profunda de 2009, da qual tratarei mais adiante neste trabalho.

The Shining continua, como percebo, a cativar leitores brasileiros e a incentivar diversas republicações e revisões do texto traduzido. Precisamente por esse motivo, é que creio ser de relevante interesse a discussão de aspectos da tradução para o português brasileiro e, em 
especial, as circunstâncias do sistema literário brasileiro que motivaram as escolhas tradutórias relativas ao apagamento e à presença de recursos de escrita que são notados no texto em língua inglesa.

\subsection{Arrepios na narrativa: características marcantes e construção dos personagens}

Assim, abordarei a seguir quais são tais recursos literários que caracterizam o texto em língua inglesa e foram, na primeira edição e em suas revisões posteriores, ora marcados ora apagados. Vou, então, adentrar no mundo dos personagens sombrios de King, destrinchar seus diálogos, monólogos e, quem sabe, encontrar alguma lógica que explique a vivacidade dos personagens em língua inglesa, antes de partir para seus "fantasmas" tradutórios em português.

Jack, Wendy e Danny são os personagens mais centrais na trama, são eles que dão vida aos acontecimentos insólitos que permeiam a narrativa. Exilados do mundo, pois a neve intensa impede a já precária comunicação das ermas montanhas do Colorado com o ambiente exterior, contam apenas consigo próprios para estabelecer qualquer laço afetivo e social no período em que habitam o Outlook.

Danny, contudo, consegue romper a barreira de silêncio que os sufoca, entrando em contato telepático com Hallorann, o chef de cozinha do Outlook que, tal qual o menino, é dotado de habilidades inexplicáveis pela ciência. Hallorann não enfrenta o inverno no hotel com a família Torrance, mas a distância não impede que Hallorann venha a ajudar o garotinho, com quem estabeleceu fortes laços de amizade, a se livrar da maléfica influência exercida pelo hotel, quando os problemas fogem ao controle.

Ao longo da infeliz trajetória da família Torrance, traços do gênero fantástico podem ser identificados, como demonstraram Filgueiras, Henrique e Reis (2011, pp. 43 a 51). As autoras, tomando por base os critérios elaborados por Todorov em sua Introdução à literatura fantástica (1992) para designar uma obra como literatura fantástica, argumentam que

[...] o fantástico é o "tempo da incerteza" no qual os personagens de uma narrativa se deparam com algum acontecimento insólito, mas não sabem precisar se ele pode ser explicado racionalmente ou se ele transcende os saberes humanos. Como bem resume Todorov, "o fantástico é a vacilação experimentada por um ser que não conhece mais que as leis naturais, frente a 
um acontecimento aparentemente sobrenatural" (1992, p. 16). (FILGUEIRAS; HENRIQUE; REIS, 2011, p. 44)

Ou seja, segundo Todorov, a trama acontece "num mundo que é nosso, que conhecemos" (1992, p.15), sem a presença de seres sobrenaturais (como vampiros ou lobisomens), mas fatos estranhos, impossíveis de serem explicados pelas leis naturais, acontecem e oferecem (ou ao leitor ou ao personagem ou a ambos)

\begin{abstract}
duas soluções possíveis: ou se trata de uma ilusão dos sentidos, de um produto de imaginação, e as leis do mundo seguem sendo o que são, ou o acontecimento se produziu realmente, é parte integrante da realidade, e então esta realidade está regida por leis que desconhecemos. Ou o diabo é uma ilusão, um ser imaginário, ou existe realmente, como outros seres, com a diferença de que rara vez o encontra. (TODOROV, idem)
\end{abstract}

Na obra do teórico, são demonstrados diversos exemplos da literatura mundial em que o fantástico apresenta-se. Para o meu objetivo, entretanto, atenho-me à análise realizada por Filgueiras, Henrique e Reis (2011) de como o fantástico se aplica à narrativa de The Shining. Segundo elas, a vacilação ocorre quando os pais de Danny ficam duvidosos quanto à capacidade de o filho prever o futuro. Questionam-se a todo tempo se seria a criança apenas muito observadora ou se seria dotada de poderes sobrenaturais. Eles não têm uma resposta certa, e quando nos é dada como certa a natureza dos dons do menino, o pior já aconteceu no Outlook, e ao fim a história chega.

Porém, antes disso, os pais resolvem levar o pequeno a um médico a fim de averiguar suas estranhas habilidades extrassensoriais. O médico tranquiliza-os, afirmando que Danny nada mais é do que uma criança muito esperta, cujas previsões do futuro são resultado de uma combinação de grande poder de observação com um pouco de coincidência. Ao ouvirem tal constatação, a mãe e o pai respiram aliviados nesse momento (embora ao longo da trama a desconfiança, em especial no caso de Wendy, volte a perturbá-los).

Percebe-se que a vacilação explicada até aqui se dá na incerteza dos personagens entenderem os sintomas de Danny como um fenômeno sobrenatural ou explicável pelas leis naturais conhecidas. Todavia, o linguista búlgaro Todorov argumenta que, para que sejam atendidos os critérios do fantástico, a vacilação deve-se dar ao menos na esfera do leitor, isto é, 
são os leitores que deverão se questionar quanto à natureza dos aspectos insólitos da história já os personagens, não necessariamente ${ }^{1}$. Filgueiras, Henrique e Reis (2011), a fim de explicar esse aspecto na narrativa de King, destacam o seguinte trecho do livro:

"Danny, when you have these ... whatever they are, do you ever recall seeing bright flashing lights before?"

"No..."

"Funny noises? Ringing? Or chimes like a doorbell?"

"Huh-uh."

"How about a funny smell, maybe like oranges or sawdust? Or a smell like something rotten?"

"No, Sir." (KING, 1977, p. 151, grifo das autoras)

Na própria explicação das autoras,

no capítulo 11 do livro, Hallorann, o cozinheiro do hotel que tem a capacidade sobrenatural da mesma ordem de Danny, explica ao garoto que, antes de ter alguma visão reveladora do passado ou futuro, ele, Hallorann, sentia o cheiro de laranjas. Sem saber dessa informação ou mesmo da conversa de Danny com o cozinheiro, o médico Dr. Edmonds, no capítulo 17, questiona o menino sobre sinais anteriores aos seus transes. (FILGUEIRAS; HENRIQUE; REIS, 2011, p. 46)

Ou seja, a referência ao aroma de laranjas, retomada em um diferente momento, sugere ao leitor - e não aos personagens - que isso pode ser um sintoma de alguma patologia que Hallorann e o menino compartilham. Ou quem sabe mesmo um sinal de paranormalidade? Dúvidas - vacilações - que cabem ao leitor tentar responder.

Outros indícios de vacilação foram identificados por Filgueiras, Henrique e Reis (2011). As autoras apontaram que Danny era atormentado por visões que um suposto amigo imaginário, Tony, lhe proporcionava (idem, p. 47). Uma das que mais o perturbava era a palavra "REDRUM". Danny, amedrontado com as sensações ruins dessas visões, questiona aos pais o significado da palavra desconhecida. Os pais, cientes do processo de alfabetização pelo qual o filho está passando, procuram estabelecer um significado para "REDRUM" - sempre supondo

\footnotetext{
1 "é necessário que o texto obrigue ao leitor a considerar o mundo dos personagens como um mundo de pessoas reais, e a vacilar entre uma explicação natural e uma explicação sobrenatural dos acontecimentos evocados" (TODOROV, pp. 19 e 20)
} 
que ele "leu" a palavra errado. Mas a criança nunca se convence com as tentativas de explicação de Jack e Wendy e continua a atrelar significados macabros para a expressão.

O leitor que se depara com a incerteza dos personagens ante as experiências incomuns que os cercam "vacila", portanto, quanto à natureza natural ou sobrenatural do texto, o que caracteriza, assim, a estrutura fantástica de um texto. De modo algo semelhante a Todorov, o próprio autor do texto ficcional, Stephen King, propõe em sua obra argumentativa, Danse Macabre que o terror na narrativa - temática pela qual The Shining é conhecida - "é a especulação desagradável que vem à mente" (1983, p. 21), que acontece antes de a narrativa revelar se os acontecimentos têm uma explicação racional ou se transcendem o conhecimento humano.

A força motriz que guia essa "vacilação" ou "especulação" na obra é sobretudo Danny, que, aos seus cinco anos, ainda precisa aprender muito sobre o mundo em que vive. Acredito que o leitor consegue, dessa forma, questionar-se se o menino não interpreta tudo de forma exagerada, mas com cores obscuras, ou se de fato algo bizarro paira no ar. Portanto, a forma como o menino escuta as palavras e lida com elas adquire importância para a estruturação do fantástico e do terror. "REDRUM", a grande palavra misteriosa que assusta o menino, é justamente aquilo que faz também o leitor mergulhar no universo assustador de dúvidas dos personagens. É a suspensão de uma explicação racional para a palavra que deixa a narrativa num tom sinistro, incerto, sempre acompanhada do olhar infantil de Danny, que aceita o sobrenatural e o repele simultaneamente, buscando, em vão, um olhar adulto que o conforte do pesadelo interno que o assola, com profecias do futuro, telepatia, pressentimentos e contato com seres imateriais.

Um grande silêncio paira entre os três familiares de forma cada vez mais intensa, mesmo antes de adentrarem o perturbador hotel incrustado na neve, o que na construção da narrativa revela-se também pela presença cada vez mais constante de fluxos de consciência. O leitor tem acesso a tais fluxos por meio da "telepatia" de Danny, o qual, notando os pais mais distantes, "acessa" seus pensamentos para tentar compreender melhor a realidade que o cerca. Veja quando o garoto "entra" na mente do pai:

shingles. i guess it'll be no problem if the flashing's ok yeah that'll be all right, that watson. christ what a character. wish there was a place for him in 'THE PLAY' i'll end up with the whole fucking human race in it if i don't watch out. yeah. shingles. are there nails out there? oh shit forgot to ask him well 
they're simple to get. sidewinder hardware store. wasps, they're nesting this time of year. i might want to get one of those bug bombs in case they're there when I rip up the old shingles. new shingles. old. (KING, 2007. p. 33)

O recurso literário de fluxos de consciência (ou monólogos) é utilizado a fim de promover o acesso à mente dos personagens, sem interferência do narrador, de modo a evidenciar o processo mental por trás de suas ações. Monólogos têm como característica a representação de certa naturalidade, isto é, a ausência de censura, com o pensamento mais íntimo dos personagens, com a principal finalidade de revelar-lhes a psiquê (HUMPHREY, 1984, p. 3). Os monólogos tentam retratar uma espontaneidade, por isso são facilmente observáveis algumas características, como as interrupções, a mudança súbita de assunto e a presença de regras gramaticais correspondentes à língua falada (tal como se pode notar no último exemplo do pensamento de Jack). Em suma, mediante a utilização dessa técnica, que pretende ser fluida e espontânea, o leitor depara-se com a mimetização de um discurso inconsciente. Assim,

o escritor nos introduz diretamente na vida íntima do personagem sem acrescentar comentários e explicações. É como se o protagonista fizesse um discurso não pronunciado, um discurso vívido. Em geral, o monólogo se realiza em orações reduzidas a um mínimo de elementos sintáticos. É um discurso descontínuo, que vai pulando de um assunto para outro, sem introdução prévia. Há também superposição de planos temporais, através da mudança de tempo e pessoa nas formas verbais. (KOHAN, 2013. p. 26)

Em King, o recurso do fluxo é representado por meio de pontuação não padrão, escrita normalmente em itálico, com a adoção de letras só maiúsculas ou só minúsculas e representação de informalidade do discurso. Veja como isso é feito em quatro monólogos:

a) Wendy:

hit by a car oh god I could never stand anything like that again like aileen but what if he's really sick cancer spinal meningitis leukemia brain tumor like john gunther's son or muscular dystrophy oh jeez kids his age get leukemia all the time radium treatments chemotherapy we couldn't afford anything like 
that but of course they just can't turn you out to die on the street can they and anyway he's all right all right all right you really shouldn't let yourself think (...). (KING, 2007. p. 155)

b) Jack:

good just one or two would be i don't care sun's over the yardarm somewhere in the world remember how we used to say that al? gin and tonic bourbon with just a dash of bitters scotch and soda rum and coke tweedledum and tweedledee a drink for me and a drink for thee the martians have landed somewhere in the world Princeton or Houston or stokely on Carmichael some fucking place after all tis the season none of us are . (idem, pp. 367 e 368)

c) Hallorann:

I'm going holy mother of Jesus I'm going off. (idem, p. 428)

d) vozes "sobrenaturais":

GET OUT OF HERE YOU DIRTY NIGGER THIS IS NONE OF YOUR BUSINESS YOU NIGGER TURN AROUND TURN AROUND OR WE'LL KILL YOU HANG UP FROM A TREE LIMB YOU FUCKING JUNGLEBUNNY COON AND THEN BURN THE BODY THAT'S WHAT WE DO WITH NIGGERS SO TURN AROUND RIGHT NOW. (idem, p. 433)

Contudo, o menino Danny nem sempre entende bem as palavras que "ouve" nos monólogos dos adultos, posto que elas não fazem parte do seu repertório léxico correspondente ao de uma criança. Tal fato leva-me a constatar mais uma característica de The Shining: a busca por simular diferentes registros da língua oral na escrita. Com isso, tem-se os diferentes personagens com diferentes representações do discurso oral, nos fluxos de consciência, diálogos e até mesmo na voz do narrador em terceira pessoa - neste caso, explico, o léxico marcado dos personagens insinua-se na narração em terceira pessoa, como se com isso o autor pudesse revelar mais intimamente os pensamentos de determinado personagem, quase numa mistura entre voz em primeira e terceira pessoa.

$\mathrm{Na}$ narrativa, identifica-se uma tendência a respeitar a seguinte categorização nos registros: infantil para Danny, étnico para Hallorann, padrão (com poucas nuanças informais) 
para Wendy e carregado de palavras de calão para Jack. Na tabela abaixo, evidencio alguns exemplos dessa caracterização (as características marcantes estão em negrito):

Tabela 1 - Registros do discurso dos personagens

$\begin{array}{cc}\text { Danny } & \text { Infantil } \\ & \text { Thing was since Tony had explained it to } \\ & \text { him. Scotty knew because his daddy did the }\end{array}$

Bad Thing, too."

(KING, p. 29)

$\begin{array}{cc}\text { Hallorann } & \text { Étnico (Black English } \\ \text { Vernacular) } & \text { "Admit it. Dis heah black boy has got at } \\ \text { least one long stripe of yaller... and it runs } \\ \text { raht up his ebberlubbin back!" }\end{array}$

(idem, p. 427)

Calão “The bitch wasn’t important now. The bitch
could wait. Now it was this dirty nigger's
turn. This dirty, interfering nigger with his
nose in where it didn’t belong."
(idem, p. 461)

Fonte: King (2007).

Nos exemplos mostrados até agora, percebo que a escrita está permeada por termos e estruturas que pretendem representar a língua falada, em outras palavras, há a presença da oralidade no texto escrito, que pode ser notada de diversas formas, seja em meio à narração seja no lugar típico reservado às falas - os diálogos. Denominarei aqui os traços típicos da língua falada, de marcas de oralidade (BRITTO, 2012), que podem ser identificadas tanto na escolha lexical quanto na estrutura sintática das orações.

Vale mencionar que as marcas de oralidade também podem revelar a utilização de variações sociolinguísticas, tanto sociais quanto geográficas (ALKMIN, 2001, p. 34), as quais serão indicadas aqui por variações não padrão, uma vez que se diferenciam da gramática 
prescritiva comumente recomendada para a escrita formal (BAGNO, p. 48) ${ }^{2}$, e valorizada (e recomendada, senão exigida) para a escrita de textos acadêmicos e jornalísticos, por exemplo.

Para compreender como a oralidade funciona em The Shining, devo primeiro analisar por que poderia se justificar a presença de uma variação não padrão na construção do discurso dos personagens. Segundo Milton M. Azevedo (1998, p. 28) ${ }^{3}$,

o discurso pode ser representado de diversas formas, desde a aderência a variações formais da linguagem literária até maneiras de se evocar a realidade por meio da manipulação de elementos emprestados de diferentes variações não padrão a fim de se conferir um toque de realismo à representação de diferentes vozes. (tradução minha) ${ }^{4}$

Assim, pode-se dizer que as variações linguísticas - e aqui se inserem as marcas típicas da língua falada - presentes numa obra literária permitem que determinado texto seja tido como mais realista. Talvez isso aconteça para aproximar a realidade do leitor com realidades transmitidas pelo modo retratado da fala dos personagens. Ou mesmo por distanciar a identificação do leitor com os personagens, mas de modo que ele reconheça determinada variação como parte de sua realidade, de sua língua, de sua sociedade.

Ademais, os diálogos e monólogos ajudam a distinguir cada personagem, dotando-lhe de voz e personalidades únicas, o que confere mais riqueza ao texto literário. É um recurso que permite que o leitor identifique o personagem "imediatamente, com base apenas na voz, sem a ajuda de qualquer explicação que o narrador pudesse proporcionar" (KOHAN, 2013, p. 58).

Detenho-me a seguir com maior atenção às linhas destinadas ao discurso de Danny e questiono-me se a representação diferenciada das "vozes" dos personagens, que muitas vezes distancia-se da norma padrão, também consegue constituir um elemento capaz de interferir na

\footnotetext{
${ }^{2}$ Lembrando que existe também uma variação padrão na linguagem falada, reconhecida pelo senso comum como "o jeito certo de se falar", de maneira pouco científica. No entanto, como estou lidando com um texto escrito, faço apenas referência à variação padrão na escrita. E quando trato da oralidade na escrita, refiro-me apenas a ecos da língua falada representados textualmente.

3 "Speech may be represented in a variety of ways, ranging from adherence to formal varieties in order to add a touch of realism to the representation of different voices."

${ }^{4}$ Todas as traduções do autor Milton M. Azevedo foram realizadas por mim. O texto original encontra-se nas notas de fim.
} 
própria estrutura da trama. Há de se responder se momentos cruciais para a história só acontecem devido aos vários registros.

Observe abaixo algumas amostras da escrita representativa do registro infantil em Danny:

a) diálogo:

'Daddy and me like the Angels,' Danny said. 'The Red Sox in the American League East and the Angels in the West. We saw the Red Sox against Cincinnati in the World Series. I was a lot littler then. And Daddy was...' Danny's face went dark and troubled.

'Was what, Dan?'

'I forget,' Danny said. He started to put his thumb in his mouth to suck it, but that was a baby trick. He put his hand back in his lap.

'Can you tell what you mom and dad are thinking, Danny?' Hallorann was watching him closely.

'Most times, if I want to. But usually I don't try.'

'Why not?'

'Well...' he paused a moment, troubled. 'It would be like peeking into the bedroom and watching while they're doing the thing that makes babies. Do you know that thing?' (KING, 2007, p. 90, grifo meu)

b) voz de Danny entremeada na narração em terceira pessoa:

[...] but he didn't really want to go to that old Jack and Jill anymore. It was for babies. He wasn't quite a big kid yet, but he wasn't a baby anymore. Big kids went to the big school and got a hot lunch. First grade. Next year. This year was someplace between being a baby and a real kid. It was all right. He did miss Scott and Andy - mostly Scott - but it was all right. (idem, p. 28, grifo meu)

Creio que a opção pela representação de uma fala infantil não é, cabe ressaltar, meramente um capricho da obra. Pelo contrário, os problemas de entendimento do "léxico adulto" que o menino apresenta constituem elemento imprescindível para a estrutura fantástica da trama (FILGUEIRAS; HENRIQUE; REIS, 2011), como já discutido anteriormente. Só é convincente para o leitor que "REDRUM" amedronta Danny porque se apresentou, desde o início, o seu modo de "falar" infantilizado, por meio dos diálogos e intercalado na voz de 
terceira pessoa, em oposição a como o discurso dos seus pais é representado. A representação de uma voz específica para Danny é imprescindível para entender por que as palavras desconhecidas o apavoram, o que confere um tom de suspense na vacilação entre o mundo real e o mundo desconhecido.

O que posso inferir, por ora, é que os recursos literários que compõem a narrativa são justamente aqueles que lhe dão cor e vida. São eles que a distinguem de outras obras e que lhe conferem algum aspecto artístico. Não é, contudo, pretensão minha argumentar a favor de ressaltar as características literárias em The Shining, que lhe permitiriam transcender a mera literatura de entretenimento e enquadrar-lhe como obra prima literária. Na verdade, aqui não cabe a discussão quanto ao seu mérito literário, mas sim reconhecer as técnicas de escrita literária que foram empregadas no livro ${ }^{5}$ e que conferem características da literatura à narrativa. Logo, meu objetivo nesta dissertação não é se aprofundar numa discussão estritamente literária, mas sim investigar algumas das marcações literárias mais notáveis na obra, notadamente os aspectos fantásticos e a representação de uma variação não padrão demonstrados ao longo deste primeiro capítulo, e os motivos pelos quais a tradução brasileira não recriou certas marcações (como a oralidade na narrativa), por que a revisão de 2005 trouxe novidades quanto a algumas marcas de oralidade, e a razão para que outras marcações literárias continuassem silenciadas, mesmo na revisão (vide capítulo 2, p. seção 2.2).

Como demonstrado anteriormente, a utilização da mimese da oralidade na escrita tem como efeito a busca de uma naturalidade e fluidez aos diálogos, monólogos dos personagens, provocando no leitor determinadas expectativas quanto ao registro empregado. Não realizar qualquer tentativa de recriação dessa oralidade fingida na tradução poderia, como argumento no último capítulo, empobrecer o texto e enfraquecer suas qualidades literárias. Poderia dizer o mesmo com relação aos elementos próprios do fantástico: diminuir-lhes sua intensidade na tradução poderia acarretar prejuízo para atender a caracterização do texto como fantástico, segundo os critérios estabelecidos por Todorov (1992) para com esse gênero literário.

No próximo capítulo, discutirei como a tradução de The Shining se insere na configuração do sistema literário brasileiro, e como o próprio texto traduzido revela seu

\footnotetext{
5 SILVA (2007, p. 136), acerca da problemática do sistema semiótico literário, argumenta que "ocorrem fenômenos de influência do centro do sistema literário sobre a sua periferia, isto é, fenômenos da influência da 'literatura canonizada' sobre a 'literatura não canonizada', pois que nesta se repercutem sempre, embora com considerável atraso temporal e marcada simplificação, características semânticas e formais da 'grande literatura"'. Assim, pode-se dizer que ainda que The Shining jamais se enquadre no cânone literário (de qualquer língua), e esteja fadada ao limbo da paraliteratura, ainda assim persistem influências da técnica literária na obra.
} 
posicionamento ao longo do tempo, isto é, a contínua publicação de novas edições, com revisões na estratégia de tradução, demonstra que o livro ainda suscita interesse junto ao público, o que, por sua vez, pode demandar uma maior atenção aos aspectos tradutórios do texto. 


\section{SILÊNCIOS E PRESENÇAS}

\subsection{Outro contexto, outra história: sob a luz da Teoria dos Polissistemas}

Em 1977, pela primeira vez era traduzido para o português brasileiro o bestseller em língua inglesa The Shining. A versão brasileira foi feita na íntegra pela tradutora Betty Ramos de Albuquerque e lançada pela editora Record (1977). Até onde foi possível pesquisar, em ferramentas de pesquisa na web, não houve críticas à tradução na época, e o livro adentrou mercado brasileiro sem maiores obstáculos.

Entretanto, posso dizer que as soluções adotadas pela tradutora Albuquerque (idem) com poucos indícios da oralidade tão notável na narrativa em língua inglesa não são isentas de quaisquer críticas, mesmo que também tenham, sim, méritos, sobre os quais comentarei mais adiante neste capítulo. Cabe-me questionar, assim, quais os motivos da grande aceitação da obra por parte do público e da crítica de nosso país; afinal texto traduzido e texto fonte divergem em tom, em especial nas falas dos personagens. Tal questionamento inicial é necessário para nos traçar um rumo pela análise de quase quarenta anos da presença da tradução da referida obra de King no Brasil. As muitas dúvidas suscitadas pelas diversas edições de $O$ iluminado, o título em português, fazem-nos partir para uma reflexão mais ampla acerca do sistema literário brasileiro, no que diz respeito à possibilidade de as suas próprias normas influenciarem a tradução. Para tentar elucidar essa questão, farei um cotejo criterioso entre texto fonte e texto traduzido para tentar explicar a aceitação do público.

Surgiu-me também a dúvida se seria viável inovar a tradução de The Shining. Em melhores palavras, se seria possível produzir uma tradução com novas propostas e estratégias e em quais circunstâncias isso poderia acontecer. Além disso, é preciso refletir se $O$ iluminado ainda teria fôlego e público para ser renovado e se recriado nas mãos de revisores e tradutores.

Tentarei, neste capítulo, analisar os pontos levantados até aqui. Antes disso, porém, alguns pontos precisam ser esclarecidos. Quaisquer críticas que faço aqui não terão caráter prejudicial, ou seja, não pretendo simplesmente apontar as críticas à tradução de Albuquerque, como se ela não tivesse nenhum ponto positivo. Pretendo, sim, comparar soluções e apontar quais as que recriaram com mais eficácia os recursos literários em língua inglesa. Como explicarei adiante, são vários os fatores que podem influenciar as escolhas dos tradutores (ou 
dos revisores e editores), por isso aqui não cabe julgar estes individualmente, mas entendê-los como atores de um processo maior: as engrenagens do sistema literário brasileiro.

Tampouco apontarei aqui desvios isolados na tradução. Não quero apontar erros de digitação, erros de compreensão de palavras ou expressões ou soluções que não possam ser inseridas dentro de uma estratégia maior de tradução. Pequenos erros assim são passíveis de ocorrer até mesmo em excelentes traduções e com renomados tradutores e sua mera presença não significa demérito ao texto traduzido (talvez se devam a uma revisão precária ou a um processo de publicação com prazos curtos).

Não se pretende criticar com objeções "palavra por palavra”, como se faz às vezes em jornais e revistas. Como dizia Paes (1990, p. 113), é um equívoco que pode incorrer na atenção desmedida

aos falsos cognatos ou falsos amigos que costumam fazer as delícias do resenhista de livros, em jornais e revistas, toda vez que se digna a atentar na tradução da obra sob resenha. O que só acontece quando ela é defeituosa o bastante para chamar-lhe a atenção; a tradução correta passa quase sempre despercebida [...]. Por saltarem à vista, os deslizes na tradução de falsos amigos dispensam o fastidioso trabalho de ter-se de cotejar a tradução com o original, e assim o resenhista pode brilhar aos olhos do leitor como um emérito conhecedor de línguas.

Partirei aqui do pressuposto de que dada estratégia de tradução literária torna-se mais ou menos aceitável pelo público de acordo com o sistema literário em que se insere - isto é, como o gênero da obra, as suas técnicas e o seu estilo se relacionam com o que é valorizado na cultura de recepção. A partir de agora, explorarei então como se dá a inserção de um livro traduzido no sistema literário de destino e, posteriormente, como $O$ iluminado tem se estabelecido no mercado editorial brasileiro. Também discorrerei a respeito das mudanças na tradução de Albuquerque, pois entendendo o que foi alterado, poderei oferecer uma hipótese que explique os motivos por trás da revisão de 2005, que buscou recriar o aspecto de oralidade na tradução.

Para compreender com mais precisão o papel desempenhado pela narrativa de King na contemporaneidade, creio que antes seja necessária uma discussão a respeito de como se comporta certa categoria da literatura - a literatura canônica -, para depois traçar um paralelo 
como outras categorias lhe circundam (e acredito que The Shining não seja uma obra canônica, pelo menos não o é hoje - discutirei isso mais adiante também).

As obras literárias tomadas como referencial por determinada sociedade podem ser denominadas canônicas. São textos considerados os mais importantes, reconhecidos por seu grande valor estético e são, no mais das vezes (mas jamais restrito a isso), recomendados para o ensino de literatura em escolas e universidades. Um cânone literário é tido como um conjunto de obras que perpassa os anos, as décadas, os séculos e até mesmo milênios, como posso dizer ser o caso de Odisseia e Eneida, textos épicos produzidos na cultura helênica da Antiguidade Clássica.

Odisseia e Eneida, por exemplo, são obras canônicas não apenas na cultura grega, mas que romperam as barreiras geográficas e exercem profunda influência na literatura ocidental. Os textos escritos logo após elas são textos que de alguma forma lhes referenciam os temas ou as estruturas, por exemplo, ou mesmo opõem-lhes. Segundo Bloom (1993), são canônicas as obras que conseguem influenciar as próximas, são textos referenciados por outros, ou mesmo têm suas propostas artísticas rejeitadas. Um cânone, assim, é produzido por obras que dialogam entre si, às vezes uma conversa respeitosa e harmônica, outras vezes uma ruptura abrupta do novo com o antigo - mas sem deixar de estabelecer um elo. Para Bloom,

o cânone, palavra religiosa em suas origens, tornou-se uma escolha entre textos que lutam uns com os outros pela sobrevivência, quer se interprete a escolha como sendo feita por grupos sociais dominantes, instituições de educação, tradições de crítica, ou [...] por autores que vieram depois e se sentem escolhidos por determinadas figuras ancestrais. (idem, pp. 27 e 28)

Essa afirmação, portanto diverge de qualquer formulação feita à primeira vista, em que se poderia imaginar que o cânone é quase estático, com obras sendo-lhe acrescentadas conforme se passam os anos. Em realidade, o que se sucede é bem diverso. O cânone é dinâmico, sua variação é diacrônica, as obras canônicas há cinco séculos não necessariamente são as mesmas de hoje.

O que faz então perdurar um livro no cânone e não outros? Como essa dinâmica acontece? Tal qual comentado há pouco, o sucesso de um texto no cânone define-se pela forma como dialoga com os vários textos literários anteriores e posteriores a ele. Pois então, é a 
capacidade de inovar os recursos literários existentes, reinterpretá-los e mesmo rejeitar-lhes. A prova cabal para a canonicidade é arrasar a tradição literária e depois subordiná-la (idem, p. 35). Bloom explica como se dá essa dinâmica de inovação na tradição literária ocidental:

O movimento de dentro da tradição não pode ser ideológico nem colocar-se a serviço de quaisquer objetivos sociais, por mais moralmente admiráveis que sejam. A gente só entra no cânone pela força poética, que se constitui basicamente de um amálgama: domínio da linguagem figurativa, originalidade, poder cognitivo, conhecimento, dicção exuberante. A injustiça final da injustiça histórica é que não dota necessariamente as vítimas de nada além do senso de sua própria vitimização. O Cânone Ocidental, seja lá o que seja, não é um programa de salvação social. (p. 36)

Ou seja, não é papel do cânone prestar-se a outros objetivos senão aqueles que o próprio cânone almeja - é a estética literária e a referência a si mesmo que constituem suas próprias engrenagens. Inovar a escrita, mas sem esquecer-se do que já é canônico. É a capacidade de ser tomado como referência pelos futuros textos, ser revivido e ser reinterpretado. Outro teste para determinar a canonicidade de um texto seria a sobrevivência em mais de uma leitura, isto é a capacidade de o texto revelar mais "segredos", leituras diversas, além da primeira lida (idem, p.33).

Tampouco é função dos textos canônicos apresentar obrigatoriamente modelos de virtude ou de qualquer ideologia. Fazê-lo só contribuiria para o desvio da função estética e de originalidade a que se presta. Tratando das interferências que uma literatura engajada em promover ideologias ou valores morais, Bloom (p. 36) argumenta que

os maiores escritores do Ocidente são subversivos de todos os valores, tanto nossos quanto deles próprios. Os estudiosos que nos exortam a encontrar a fonte de nossa moralidade [...] perderam o contato com a realidade social em que vivemos. Se lermos o Cânone Ocidental para formar nossos valores morais sociais, políticos ou pessoais, creio firmemente que nos tornaremos monstros de egoísmo e exploração. Ler a serviço de qualquer ideologia é, em minha opinião, não ler de modo algum. [...] Ler a fundo o Cânone não nos fará uma pessoa melhor ou pior, um cidadão mais útil ou nocivo.

O cânone literário, seja de qual âmbito for, do ocidental ou do nacional, é como uma complexa rede, com diversos pontos ligados a tantos outros. Se, ao longo do tempo, um 
determinado ponto parar de fazer ligações com novos pontos ou deixar de influenciar novos pontos, este elo se enfraquece e pode deixar de fazer parte da rede. Também é possível que pontos que não estavam na rede, passem a integrar-lhe depois de um tempo. Note-se que esta é uma rede mais que guarda mais semelhanças com uma rede de computadores, por exemplo, do que com uma rede de tecido.

A dinâmica do cânone é de fato bem complexa. Não é possível determinar quais obras vão compô-lo. Bloom (p.28) ilustra essa indefinição com o exemplo dos gêneros literários. Ao que tudo indica, os vários gêneros literários não estão distribuídos igualmente no repertório canônico ao longo dos anos. Em determinadas épocas, pode-se notar que estavam mais em voga os épicos, os romances históricos, as aventuras em prosa etc. Assim, admite-se que o Cânone Ocidental tende a permitir inovações expressivas, não apenas quanto ao estilo dos autores, mas quanto à estrutura de escrita das obras de seu repertório.

Faz-se imprescindível notar, contudo, que o cânone de dada literatura, embora dinâmico, não é tão suscetível a mudanças assim. Afinal, trata-se de obras que exercem influências no decorrer do tempo. Qualquer mudança no cânone precisa ser estudada historicamente, assim as mudanças são o reflexo, por exemplo, da presença de determinada obra nos livros didáticos ou mesmo da existência de suas reedições para venda, tudo isso analisado ao longo dos anos.

Um exemplo a ser citado seria a encomenda de traduções. Afinal, como o exemplo de Eneida e Odisseia, as obras não precisam ficar restritas às suas culturas originárias. A tradução é uma forma de romper fronteiras e dar nova vida ao texto literário (VIEIRA, 1996, p. 134) ${ }^{6}$. A constante publicação de novas traduções ao longo da história é um indício de que a obra provoca interesse de novos públicos e isso fortalece sua posição no cânone literário daquela sociedade, principalmente se o texto for capaz de ser refletido nos trabalhos dos escritores de lá. Se chegar a influenciar obras que venham a compor o cânone daquela cultura, então o êxito da obra original como cânone é ainda mais evidente.

Barrento (2014, p.15) propõe inclusive que "as traduções do cânone [...] são muitas vezes traduções de traduções" - estas, capazes mesmo de influenciar a nova tradução, produzindo-se assim, versões intermédias da obra canônica ou, como diz, palimpsestos na

\footnotetext{
6 “A tradução permite não só a sobrevivência de uma obra, mas também sua canonização em níveis transnacionais e transculturais, o que constitui um fato importante para a cultura originária, uma vez que ela também sobrevive através das suas obras traduzidas". (VIEIRA, p. 134)
} 
tradução. A tradução do cânone seria mesmo capaz de revelar o estágio da língua na história (BARRENTO, 2014, p. 17).

Lembremo-nos que não havia de existir um cânone nacional (britânico, por exemplo) se não existisse um cânone mais abrangente (ocidental, por exemplo). Ora, se toda obra canônica fosse automaticamente universal, não caberia a divisão por categorias regionalizadas. Assim, depreende-se que o cânone é dinâmico em termos diacrônicos e não é, necessariamente, universal, posto a existência de subdivisões regionais.

Temos falado até agora em cânone(s), mas as obras canônicas não são as únicas a povoar todo o território da literatura de uma dada sociedade. Não haveria um cânone de obras prestigiadas se não houvesse outros conjuntos de literatura que lhe fizessem atrito dentro do espectro de um sistema literário. E se, de tanto atrito exercido, admite-se a possibilidade de uma obra não canônica hoje passar a ser considerada canônica amanhã.

Esbarro então na noção de polissistemas literários, formulada por Even-Zohar (1990). Dentro de um sistema literário coexistem vários sistemas de literaturas e que quanto mais próximos do centro, mais canônicos e valorizados os sistemas tendem a ser. Aqueles mais periféricos são também menos conhecidos e menos capazes de exercer influência dentro do sistema. Todavia, os sistemas não são estáticos, há uma dinâmica que os fazem aproximar-se ou afastar-se do centro, de acordo com o período analisado, sob uma óptica diacrônica ou sincrônica (idem, pp. 13 e 14). O conjunto dos vários sistemas compõe o que o autor denomina de polissistema.

Segundo o referido autor, as inúmeras obras de literatura existentes dentro de um sistema são agrupadas em sistemas menores, de acordo com sua classificação e com a relação hierárquica que estabelecem com a literatura canônica (centro) do sistema. Há então, por exemplo, os livros infantis, a literatura de entretenimento, os romances policiais etc., reunidos no seu sistema específico. O conjunto deles é que faz o polissistema. Nas palavras de EvenZohar:

Esses sistemas não são iguais, mas hierarquizados na esfera do polissistema. É a luta permanente entre os muitos estratos, como sugere Tynjanov, que constitui o estado sincrônico (dinâmico) do sistema. É a vitória de um estrato sobre outro que constitui a mudança no eixo diacrônico. (idem, p.14) 
Um parêntese, porém: os gêneros literários ou as temáticas dos textos não definem o sistema em que se encontram. Afinal, o cânone literário de uma sociedade não é composto apenas por obras com o mesmo gênero ou com a mesma estrutura literária. Pelo contrário, o cânone é diversificado, com um repertório que, além de se modificar ao longo do tempo, também se amplifica. Dentro do cânone de um sistema literário, pode-se ter desde uma tragédia a uma poesia do início do século XX, de um épico a um romance histórico.

Retomando os estratos do polissistema, sabe-se que sua classificação não acontece aleatoriamente. Segundo Even-Zohar, há um repertório - "agregado de leis e elementos [...] que governam a produção de textos" (idem, p. 17) - dentro do sistema literário que rege o que virá a ser mais central no sistema e o que tenderá à periferia. Esse repertório pode ser também canônico ou não, isto é pode ou não se basear no próprio cânone, e dita, mesmo que de forma sutil e indireta, como as obras se comportam no sistema. Faz-se notar que, segundo esse autor, “obviamente, o repertório canonizado é incentivado por elites conservadoras ou inovadoras e, assim, fica restringido por padrões culturais que regem seu comportamento" (idem, p. 18).

De acordo com a Teoria dos Polissistemas, nome que se atribui às ideias de Even-Zohar, embora seja visível um padrão hierárquico entre os sistemas, isso não significa que se possa atribuir uma relação de inferioridade para com os sistemas periféricos, já que a

canonicidade não é, desse modo, característica inerente de atividades textuais em qualquer instância: não é eufemismo para 'boa' ou 'má' literatura. O fato de que certas características tendem, em determinados períodos, a agrupar-se em determinados status não significa que elas apresentem uma pertinência "essencial" a algum status. (idem, p. 15)

Tendo em mente essa consideração, vou me deter agora, contudo, a uma categoria específica de um polissistema literário, a qual designarei aqui de paraliteratura, que

pelo contrário, não avulta de igual modo uma conotação desqualificante: os textos literários que representam a extensão do conceito, como decorre do morfema prefixal para-, situam-se ao lado, junto da literatura, constituindo uma 'literatura periférica' ou uma 'literatura marginal"' (SILVA, 2007, p. 115) 
Cabe a ressalva de que, de modo diverso de Even-Zohar (1990), que trata toda literatura periférica apenas como não canônica, Silva (2007) afirma que a paraliteratura é periférica e também tende a ser não literária, isto é, não apresenta inovações em termos de recursos literários, ao contrário da literatura de vanguarda, que considera literária, no caso, com potencial de se tornar literária, já que propõe renovações estéticas (embora não esclareça se a considera marginal). Porém, o teórico israelense Even-Zohar alerta que

quando não há 'sub-cultura' (literatura popular, arte popular, 'cultura inferior' em qualquer sentido etc), ou quando não se permitem pressões reais na cultura canoizada, existe pouca possibilidade de haver uma cultura canonizada vital. Sem o estímulo de uma forte 'sub-cultura', qualquer atividade canônica tende a, de forma gradual, petrificar-se. (EVEN-ZOHAR, 2007, pp. 16 e 17)

Afinal, considero o presente uma matéria muito incerta para estabelecer quais textos sobreviverão ao longo do tempo com sólida reputação. E não é impossível que um texto paraliterário um dia deixe a periferia com direção ao centro. Se for o repertório o elemento a definir a canonicidade de um sistema, ele também define a sua marginalidade. Se o mesmo repertório fica sujeito a mudanças, rupturas de toda a sorte ${ }^{7}$, não é irreal dizer que uma obra periférica um dia se torne canônica.

É importante destacar que Silva, como Even-Zohar, não considera a fronteira entre literatura e a paraliteratura sólida e estática, mencionando exemplos de textos "valorados como literários" que são relegados, ao longo dos períodos históricos, à paraliteratura (1990, pp. 128 a 130). Do mesmo modo, acredita que gêneros não canonizados possam conseguir a sua canonização num dado momento da história, tal como a "ascensão do romance da periferia até o centro do sistema semiótico literário" (idem, pp. 135 e 136), na época moderna.

Outrossim, a paraliteratura seria todo aquele conjunto de obras que se utilizam de recursos literários pré-estabelecidos pelo cânone. Em geral, não apresentam inovações na estrutura ou na utilização artística dos signos linguísticos (SILVA, 2007, pp. 115 e 136), o que já as diferenciam da literatura de vanguarda, as quais, embora não ocupem a área mais central

\footnotetext{
7 "While some of these laws and elements seem to be universally valid since the world's first literatures, clearly a great many laws and elements are subjected to shifting conditions in different periods and cultures. It is this local and temporal sector of the repertoire which is the issue of struggle in the literary (or any other semiotic) system." (EVEN-ZOHAR, 1990, p. 18)
} 
no sistema, tentam utilizar-se de transgressões dos modelos estabelecidos e valorizados, possibilitando uma nova perspectiva artística. Os textos de vanguarda geram, portanto um atrito direto com o cânone e são eles, em geral, que costumam adentrar ao diminuto círculo central do sistema.

Destarte, não é difícil supor os motivos pelos quais uma obra paraliterária enfrenta mais dificuldade em tornar-se canônica (embora não seja impossível, como já dito). Como não apresenta inovações, não há sentido em competir com outra obra que já faz parte do cânone e apresenta os mesmos recursos. Mesmo tornando-se popular junto ao público leitor durante um tempo, nada garante sua continuidade com as novas gerações de leitores e estudiosos da literatura ${ }^{8}$. Ao contrário das obras de vanguarda, a paraliteratura não provoca atrito significativo com as obras mais centrais do sistema, pois se utiliza justamente de suas formas e temas (seu repertório atual) para existir, mas sempre com menor êxito literário, se comparadas à grande literatura. Como bem argumenta Silva (2007, p. 131),

a paraliteratura, pelo contrário, revela-se destituída desta capacidade de inovação e de questionamento em relação aos seus códigos, cujas regras e convenções tanto o autor quanto o leitor típico do texto paraliterário encontram-se, pois, em mudança contínua, ora tão lenta que se configura como estabilidade, ora tão célere e tão tumultuária que provoca rupturas com as normas e os padrões estabelecidos [...], ao passo que os códigos do texto paraliterário se transformam tão pouco e tão demoradamente que parecem estáticos, repercutindo-se neles, sempre com grande atraso, com caráter residual e marcada simplificação, as inovações estilísticas, técnicocompositivas, semântico pragmáticas, etc., entretanto introduzidas e consagradas no policódigo da literatura.

Todavia, pode-se dizer que no polissistema literário (e nele inclusa a paraliteratura), convivem sistemas, digamos assim, "temáticos" (ou subgêneros). Isto é, tem-se um sistema de narrativas românticas, que podem conter desde Pride and Prejudice, de Jane Austen, ao último romance açucarado de um autor da moda. A primeira obra também faz parte do cânone, a segunda não, mas os leitores que buscam ler apenas uma história de amor podem se deparar

\footnotetext{
${ }^{8}$ Como estou tratando de sistemas que giram em torno de um cânone, é importante fazer um adendo: nem sempre as obras mais vendidas (os bestsellers) coincidem com o cânone. O fato de haver um livro figurando entre os mais vendidos hoje não significa que amanhã ele terá força o bastante para cativar novos leitores, fazer com que novos escritos baseiem-se nele ou entrar para o rol dos livros de história da literatura; não há relação entre canonicidade e sucesso comercial. Como já foi dito, o tempo é característica inerente dos textos canônicos; somente uma análise diacrônica dirá quais elementos de fato integram o cânone.
} 
com ambas e ler ambas. Ou seja, há um grupo de interesse, que está em busca de leituras por temas, não necessariamente pela sua qualidade. Nesse grupo conviveriam tanto os leitores cultos, versados nas obras canônicas, quanto os leitores que não se interessam por questões literárias, mas buscam a leitura fruitiva, para fins de entretenimento (SILVA, 2007, p. 134).

Por conseguinte, posso argumentar que, dentro de cada um dos subconjuntos do polissistema literário, há também um conjunto ainda menor de obras "canônicas", as quais as obras periféricas fazem referência e seguem como "modelos", a serem transgredidos ou não. Os textos literários que tendem ao seu centro podem corresponder aos textos canônicos do polissistema literário maior ou podem também ser "canônicos" dentro do pequeno conjunto (sempre com a mesma dinâmica entre centro e periferia, previamente mencionada), ainda que sejam considerados paraliterários em comparação ao polissistema literário maior ${ }^{9}$.

\subsection{Outra língua, outros sustos: recursos literários recriados na tradução de The Shining}

O polissistema literário de uma sociedade não precisa (e quanto mais complexa a sociedade, mais isso é percebido) ser composto tão somente de obras escritas originalmente em língua vernácula. Em geral, existe num sistema a presença das traduções, que podem ter um peso maior ou menor dentro dele como um todo, ou um peso maior no cânone e menor nos sistemas marginais, e assim por diante. As traduções podem integrar os mais variados conjuntos dentro do sistema e serem percebidas ou não como traduções.

Toury (1995) discorre a respeito de normas que regem dada dimensão sociocultural. As normas, e entendemo-las em relação de semelhança à noção de repertório proposto por EvenZohar (1990), podem ser mais rígidas ou mais fracas, mas inexoravelmente essenciais para garantir o devido funcionamento de uma ordem social, inclusa aqui a atividade tradutória. Nem a transgressão a uma norma seria capaz de invalidá-la, apenas acarretaria em algum tipo de consequência (TOURY, 1995, p. 55).

A maneira como os textos serão traduzidos dependem também das normas que regem o sistema literário em questão. As traduções não passam incólumes na engrenagem do sistema,

\footnotetext{
9 "However, with a polysystem on must not think in terms of one center and one periphery, since several such positions are hypothesized. A move may take place, for instance, whereby a certain item (element, function) is transferred from the periphery of one system to the periphery of an adjacent system within the same polysystem, and may not move on to the center of the latter." (EVEN-ZOHAR, 1990, p. 14)
} 
posto que tais normas afetam as escolhas tradutórias, seja por parte do tradutor seja do revisor seja do editor. Toury (idem, p.56) demonstra ser a tradução uma atividade que acaba por envolver no mínimo duas línguas e duas culturas, ou seja, pelo menos dois tipos de sistemasnormas. O valor intrínseco de uma tradução consistiria em dois elementos:

(1) ser um texto numa determinada língua, e desse modo ocupando uma posição ou ocupando um espaço na devida cultura, ou em seu determinado setor;

(2) constituir uma representação naquela língua/ cultura de outro texto préexistente em alguma outra língua, pertencente a alguma outra cultura e nela ocupando uma posição definida. (idem)

Dessa forma, o tradutor tem diante de si duas opções: sujeitar-se (1) às normas do texto original ou (2) às normas próprias da cultura alvo, ou "no setor que abrigará o produto final" (idem). É claro que seria extremo um tradutor que optasse por apenas um dos caminhos, e aquele que optasse por tão somente seguir as normas relativas à cultura do texto original poderia sofrer consequências (idem, p. 64) relativas tanto à revisão quanto à aceitação de seu texto na cultura alvo.

Toury (idem, pp. 58 e 59) separa as normas em algumas categorias, que regem a tradução desde a "política de tradução", isto é, as decisões macro que na cultura alvo determinam quais os tipos de texto a serem traduzidos e quais serão suas posições no sistema, até as normas que influenciam nas “omissões, acréscimos, mudanças de local e manipulação da segmentação" textual.

O autor explica que os tradutores não são passivos perante as normas como pode parecer a priori, na verdade são eles mesmos atores do processo que constrói e valida as normas de tradução, por meio da crítica, de ideologias, e da própria existência de centros formadores de tradutores (idem, p. 62). Tal fato acarreta na concorrência de mais de uma norma na cultura, com

seguidores próprios e posição própria na cultura como um todo: as [normas] que dominam o centro do sistema, e assim direcionam o comportamento tradutório do dito mainstream, concomitantemente com os resquícios de conjuntos de normas anteriores e os rudimentos de novas normas, circundando na periferia. (idem, pp. 62 e 63) 
Levando em consideração a função que as normas de tradução desempenham em dado polissistema literário, pode-se concluir que na cultura de tradução brasileira existem também normas que estruturam nosso mercado editorial e exercem influência em como tradutores, revisores e editores lidam com um texto. Tal como Toury argumenta (idem, p. 59), existem normas que podem, sim, pertencer a apenas um tipo de texto.

A partir de agora, será analisado com mais atenção o caso do polissistema brasileiro e o caso da tradução do livro de que trato, $O$ iluminado. Parto da ideia de que ele não integra o centro do sistema, pois não é uma obra canônica segundo os critérios já analisados: não se encontra a narrativa de King em coletâneas de grandes clássicos, tampouco o autor costuma ser abordado nos estudos para a formação da (grande) literatura brasileira, nem autores consagrados brasileiros baseiam-se em sua obra. No entanto, não se pode dizer que a história de horror que assusta leitores mundo afora carece de importância em terras brasileiras.

Nosso sistema literário é o de uma sociedade complexa, com mais de 500 anos de história documentada, cujos primeiros indícios de atividade literária remontam ao século XIV, e cuja literatura com características mais brasileiras (em oposição à literatura portuguesa) começa a despontar no século XIX(CÂNDIDO, 1997, p. 26 a 28). O papel desempenhado pela literatura estrangeira na formação da literatura brasileira foi crucial em seus primórdios e o surgimento de traduções publicadas no Brasil oficialmente (posto que, antes da vinda família Real, elas eram proibidas ${ }^{10}$ ) deu-se apenas alguns anos antes do início da literatura mais sistematicamente brasileira, no século XIX (CÂNDIDO, 1997, p. 28) ${ }^{11}$.

As traduções produzidas e publicadas no Brasil começaram a se intensificar por volta do século XX, na década de 1930. Tal façanha ocorreu devido à política do presidente Getúlio Vargas de se cobrar impostos em produtos importados, dentre os quais livros, visto que o mercado de livros nacional era tomado por edições estrangeiras, sobretudo oriundas da França e de Portugal. Daí sucedeu-se que a produção de textos traduzidos de obras de sucesso tornou-

\footnotetext{
10 “A impressão de jornais e livros só se tornaria possível após a vinda de D. João VI para cá, quando o Brasil finalmente se abre para o mundo, inclusive o mundo das ideias. Em 1808 fundou-se no Rio a Impressão Régia, a nossa primeira tipografia, já que as tentativas anteriores de aqui instalar prelos haviam sido severamente coibidas pelo governo colonial". (PAES, 1990, p. 13).

11 “[...] a atenção se volta para o início de uma literatura propriamente dita, como fenômeno de civilização, não algo necessariamente diverso da portuguesa. Elas se unem tão intimamente, em todo o caso, até meados do século XIX, que utilizo em mais de um passo, para indicar esse fato, a expressão "literatura comum" (brasileira e portuguesa)".
} 
se um bom negócio, ainda mais se considerando que o público ledor brasileiro sempre tivera, historicamente, seus olhos voltados para a produção do exterior (MILTON, 2008, p. 165).

Desde então, a presença de textos traduzidos é marcante - notadamente as traduções da língua inglesa, e as livrarias estão repletas de exemplares em sua seção de "literatura estrangeira". Porém, nem só de grandes obras da literatura britânica ou estadunidense (por exemplo) vive o mercado de traduções no Brasil. São comuns as edições das obras mais vendidas no estrangeiro, e não raro os tradutores são solicitados a produzir a versão brasileira em prazos muitas vezes ínfimos ${ }^{12}$.

A coexistência de obras literárias estrangeiras traduzidas com obras nacionais não significa que as primeiras sejam mais valorizadas que as últimas, pois nosso cânone literário de hoje integra muito bem a produção brasileira, mesmo com a massiva presença da produção estrangeira (especialmente a estadunidense). Entretanto, dentro do sistema literário há posições que não são ocupadas expressivamente por obras nacionais. É o caso da literatura de horror, isto é, aquela cujos temas se voltam para o grotesco e podem também ser lidas a partir de uma perspectiva da literatura fantástica (vide "Arrepios na narrativa", capítulo 2, terceiro subcapítulo).

Não há uma sólida tradição de histórias de terror na literatura brasileira (FRANÇA, 2008, p. 1) ${ }^{13}$, e esse é um dos motivos de $O$ iluminado estabelecer-se com tanto sucesso entre nosso meio. É claro que a obra goza de prestígio no seu país de origem (idem, p. 2), ainda que lá também não seja considerada canônica, mas as constantes reedições no Brasil, inclusive com mudanças na tradução, mostra que aqui é tida com alguma importância, ao menos para o sistema de que faz parte.

Barrento (2014, pp. 14 e 15) menciona apenas as traduções canônicas com relação à sua hipótese de "traduzir na história", mas creio ser possível tomar emprestado esse conceito e aplicá-lo ao processo de tradução de The Shining no Brasil nas últimas décadas, guardadas as devidas proporções existentes entre uma obra já considerada canônica e outra que ainda parece ser tida como paraliteratura.

\footnotetext{
12 "Salvo as poucas e honrosas exceções de praxe, nossos editores se preocupam antes em publicar muito do que em publicar bem, pelo que não hesitam em confiar o trabalho de tradução a quem o possa fazer mais depressa e/ ou mais barato, duas condições que são inimigas da competência profissional”. (PAES, 1995, p. 118)

13 "Embora seja um subgênero literário bastante difundido em língua inglesa, a ficção de horror parece não ter a mesma representatividade na tradição literária brasileira”.
} 
Desde 1977, quando $O$ iluminado foi traduzido, surgiram diversas edições no Brasil, publicadas por várias editoras. Abaixo, selecionei as mais importantes, isto é, excluí da tabela, e, por conseguinte, da pesquisa, aquelas que mantiveram o texto idêntico ao de 1977, sem qualquer revisão, e deixei todas as edições da editora Objetiva, que é quem detém os direitos autorais para a publicação da obra no Brasil hoje (a Suma de Letras faz parte da Objetiva):

Tabela 2 - Edições de $O$ iluminado no Brasil

\begin{tabular}{|c|c|c|c|}
\hline Edição (ano) & Editora & Tradução & Revisão \\
\hline 1977 & Record & \multirow{6}{*}{$\begin{array}{c}\text { Betty Ramos de } \\
\text { Albuquerque }\end{array}$} & 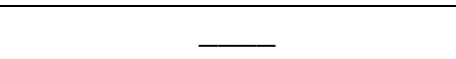 \\
\hline 1987 & Nova Cultural & & $\begin{array}{c}\text { Sônia Peçanha; Tereza de } \\
\text { Fátima da Rocha; e Izabel } \\
\text { Cristina Aleixo }\end{array}$ \\
\hline 1999 & Objetiva & & Não houve revisão. \\
\hline 2005 & Objetiva & & $\begin{array}{c}\text { Tereza de Fátima da } \\
\text { Rocha; Izabel Cristina } \\
\text { Aleixo; e Sandra Pássaro }\end{array}$ \\
\hline 2009 & Objetiva & & $\begin{array}{c}\text { Fátima Fadel e Héllen } \\
\text { Dutra }\end{array}$ \\
\hline 2012 & Suma de Letras & & Não houve revisão. \\
\hline
\end{tabular}

Fonte: Filgueiras, Henrique e Reis (2011).

É coerente afirmar que a obra suscita interesse no mercado, pois, de outro modo, não faria sentido a publicação de novas edições. Aliás, seria um fato curioso a realização de três revisões (1987, 2005 e 2009). Pode-se supor, inclusive, que a existência de uma revisão serve para atender às exigências de um público mais atual, que preze por critérios diferentes daqueles da época da primeira publicação. Cabe também questionar quando seria realizável uma nova tradução, e se o momento atual já não demandaria novas e contemporâneas escolhas tradutórias.

Retomando o primeiro capítulo, relembro de alguns dos recursos artísticos explorados por King, em The Shining: as marcas de oralidade - diferentes em cada um dos personagens e a estrutura fantástica. Cabe verificar agora se os recursos foram mantidos quando do lançamento da tradução; se não tiverem sido, questiono-me se há algum motivo que explique a sua ausência.

Em comparação com o texto fonte, como mostrarei adiante, a tradução revela-se mais formal e com ausência de marcas de oralidade. Não é possível uma resposta exata que explique o que ocorreu, mas várias hipóteses fazem-se críveis. As normas literárias que regiam o sistema literário brasileiro na década de 1970, principalmente aquelas nas quais as traduções 
embasavam-se, poderiam ser menos flexíveis e demandar um texto mais próximo da gramática normativa. Uma tradução carregada de resquícios da língua oral poderia afugentar o públicoalvo do livro, que poderia tachar a tradução como um trabalho "mal feito" (BRITTO, 2012, pp. 84 a 86$)$.

Outra explicação seria um prazo reduzido para elaboração e revisão do texto traduzido, o que poderia ter motivado escolhas tradutórias que reproduzissem com menos criatividade as marcas de oralidade, o que requer um tempo mais curto para a conclusão, se se comparar com a reflexão e a pesquisa necessárias para a escrita criativa da oralidade. Lembrando que o tradutor não se encontra numa posição isolada no âmbito do mercado editorial e não só nele recai o ônus ou o bônus de uma tradução. Revisores e editores também são responsáveis pelo resultado final de uma tradução (TOURY, 1995, p.58). A existência desses atores participantes do processo tradutório ajuda na compreensão de que Albuquerque (1977) não possa, sozinha, ser responsável por toda sorte de soluções na tradução.

No entanto, ainda que o processo das escolhas tradutórias das marcas de oralidade em O iluminado possa ser justificado pela série de fatores elencados até aqui (polissistemas, sistema literário brasileiro, atores do processo etc), não se exclui a possibilidade de se realizar uma crítica à tradução, que poderia apontar para novos caminhos pelos quais as futuras revisões ou retraduções da obra poderiam seguir. Analisarei a seguir aspectos relativos às marcas de oralidade (BRITTO, 2012) e à análise estruturalista do fantástico de Todorov (1992) da tradução de Albuquerque (1977), com base na argumentação de Filgueiras, Henrique e Reis (2011).

O texto traduzido que demonstrarei nos próximos exemplos foi retirado da edição de 1999, que na verdade corresponde ao texto da primeira versão, de 1977, com a vantagem de terem sido corrigidos pequenos erros ortográficos, portanto sendo uma melhor opção para análise, sem que se passe por esses pequenos obstáculos. Sabe-se que a revisão entre essas edições foi realizada por outros profissionais, mas como não houve mudança perceptível na estratégia de tradução quanto às marcas de oralidade, creio não haver ressalvas para a utilização da versão mais recente. Quanto ao texto fonte, utilizo a edição de 2007, da editora Hodder, visto que não há mudança substancial com relação à primeira versão e às mais recentes.

Para atingir meus objetivos, realizarei uma comparação entre trechos selecionados, nos quais poderão ser notados os recursos literários já debatidos no capítulo anterior. Farei uma seleção abrangendo os personagens mais proeminentes na narrativa, bem como extrairei trechos 
de diferentes momentos, a fim de demonstrar que não são características isoladas, mas podem ser observadas por toda sua extensão.

Considerando o exposto, começarei abordando as falas do personagem Dick Hallorann. Antes, porém, segue uma breve análise da caracterização de Hallorann na narrativa.

Hallorann é o chef da cozinha do hotel onde os outros três personagens principais (Jack Torrance, o pai, Wendy Torrance, a mãe, e Danny Torrance, o filho) residem durante o inverno, devido à função de zelador exercida por Jack. Hallorann é proveniente do sul dos Estados Unidos e sua fala é caracterizada como uma representação escrita do African American Vernacular English (ou Black English), que não é apenas um sotaque, mas uma variedade do inglês que apresenta estruturas e vocábulos próprios, bem como uma carga histórica, política e social, segundo Rickford (1998, 1999, 2000 apud FILGUEIRAS; HENRIQUE; REIS, 2011, p. 70). Também vale mencionar que o Black English apresenta várias características próprias, diferentes das variedades padrão do inglês estadunidense (WEKKER; WEKKER, 1993).

Assim, tem-se o seguinte trecho de uma conversa bem informal de Hallorann com Danny (grifos meus):

I remember the strongest shine I ever had that way ... I'm not liable to forget. It was 1955. I was still in the Army then, stationed overseas in West Germany. It was an hour before supper, and I was standin by the sink, givin one of the KPs hell for takin too much of the potato along with the peel. I says, 'Here, lemme show you how that's done.' He held out the potato and the peeler and then the whole kitchen was gone. Bang, just like that. You say you see this guy Tony before ... before you have dreams? (King, 2007, p. 42)

As partes grifadas representam traços provenientes da referida variedade, que os leitores identificam prontamente no texto. O mais frequente é o "gerúndio terminado em "in" em vez de “ing”' (RICKFORD, 1999, p. 4 apud REIS, HENRIQUE, FILGUEIRAS, 2011, p. 71). Além disso, toda a conversa entre ele e a criança é pautada pela informalidade, e é nas conversas entre os dois personagens que a "voz" de Hallorann é mais permeada por marcadores de oralidade do African American Vernacular English.

Analiso, então, a tradução publicada (grifos meus): 
Lembro-me da visão mais forte que já tive... não sou dado a esquecimento. Foi em 1955. Eu ainda estava no Exército, servindo na Alemanha Ocidental. Faltava uma hora para o jantar, e eu estava parado perto da pia, brigando com um dos ajudantes da cozinha porque desperdiçava a batata ao descascá-la. Dizia eu: "Olhe aqui, deixe-me mostrar como se faz isto". Ele segurou a batata e o descascador e a cozinha inteira desapareceu. Simplesmente desapareceu. Você diz que vê este cara, Tony, antes... de sonhar?" (Tradução de ALBUQUERQUE, 1999, p. 57)

Nesse trecho já não há mais a conotação presente no texto em inglês de uma conversa informal, com um personagem que fala uma variedade marcada na cultura estadunidense. Ao contrário: há um discurso demasiado formal para o português brasileiro. Os grifos em português destacam alguns marcadores de formalidade, o que acaba por trazer uma conotação de formalidade que inexiste no texto de língua inglesa. $\mathrm{O}$ emprego constante da ênclise não é próprio de um discurso informal e oral no linguajar brasileiro (BAGNO, 2008, p.44).

Ainda mais um exemplo:

Or you take the race track. I go a lot, and I usually do pretty well. I stand by the rail when they go by the starting gate, and sometimes I get a little shine about this horse or that one. Usually those feelins help me get real well. I always tell myself that someday I'm gonna get three at once on three long shots and make enough on the trifecta to retire early. It ain't happened yet. But there's plenty of times I've come home from the track on shank's mare instead of in a taxicab with my wallet swollen up. Nobody shines on all the time, except maybe for God up in heaven. (KING, 2007, p. 43)

Todos os grifos revelam, mais uma vez, as características da fala de Hallorann, em especial no nível gramatical. Na tradução, contudo, essas marcas foram apagadas e optou-se pela adequação à gramática normativa e por soluções mais formais e menos orais. Veja os exemplos dessa formalidade, grifados:

Veja, por exemplo, quando vou ao hipódromo. Vou lá com frequência e, geralmente, me dou muito bem. Fico parado junto à grade quando vão largar, e às vezes me vem uma intuição sobre esse ou aquele cavalo. Geralmente, essas sensações ajudam a me sentir muito bem. Digo sempre a mim mesmo que qualquer dia desses vou apostar num azarão e ganhar o suficiente para logo me aposentar. Isso ainda não aconteceu. Mas houve ocasiões em que voltava do hipódromo para casa a pé, em vez de tomar um táxi, com a carteira 
recheada. Ninguém acerta o tempo todo, com exceção talvez de Deus, lá no céu. (Tradução de ALBUQUERQUE, 1999, p. 58)

Entretanto, há a interessante escolha "me dou muito bem" (segunda linha do trecho acima), com a presença da próclise no lugar da recomendada ênclise, para início de oração, que melhor reproduz a situação informal e é um registro de oralidade.

No caso das falas de Jack, a formalidade na tradução aparece inclusive em momentos de grande tensão, nos quais, na versão em inglês, o personagem utiliza expressões chulas e não demonstra qualquer preocupação em uma fala polida e bem educada. Contrastando as duas versões, tem-se aqui o retrato de um tom na narrativa brasileira muito mais formal do que a narrativa em inglês, com presença do verbo "haver", que conota certa formalidade no discurso (grifo meu):

shingles. $i$ guess it'll be no problem if the flashing's ok yeah that'll be all right, that watson. christ what a character. wish there was a place for him in 'THE PLAY' $i$ 'll end up with the whole fucking human race in it if $i$ don't watch out. shingles. are there nails out there? oh shit forgot to ask him well they're simple to get. sidewinder hardware store. wasps, they're nesting this time of the year. i might want to get one of those bug bombs in case they're there when $i$ rip up the old shingles. new shingles. old. (KING, 2007. p. 33)

Em português:

telhas. acho que não vai haver problema se estiver bem calefetado. é... estará tudo bem. aquele watson. deus, que figura. quem me dera ter um papel para ele na "PEÇA". vou botar toda a miserável humanidade nela se eu não tomar cuidado. é... telhas. há pregos por lá ? que merda, esqueci de perguntar. bem, são fáceis de se conseguir. loja de ferragens de sidewinder. vespas. nesta época do ano estão acasalando. devo precisar de uma daquelas bombas contra insetos, caso haja por alguma por lá quando retirar as telhas velhas. telhas novas. velhas. (Tradução de ALBUQUERQUE, 1999, p. 47)

Nos monólogos de Wendy e Jack, não se nota qualquer marcação que os identifique individualmente - as falas foram planificadas. O leitor das primeiras edições brasileiras pode 
ter a impressão, desse modo, de que o casal tem um relacionamento pautado por formalidade em vez de casualidade e intimidade. Ou seja, a recriação de um registro diferente daquele original acaba por empalidecer a leitura. Uma cor menos marcante do que poderia ser, fosse analisada com atenção a importância que as falas na ficção podem trazer para a construção dos personagens, enriquecendo o texto e dando-lhe camadas de significado. (KOHAN, 2013, p. 61)

Como dissera, a única personagem feminina da história, Wendy, tende a ter a informalidade representada em seu auge nos monólogos. Há de se imaginar que, como a narrativa foi escrita dessa maneira, algum aspecto na caracterização do personagem pode ser depreendido da leitura. De acordo com minha interpretação, por exemplo, suponho que Wendy sinta-se mais confortável em seus pensamentos, por isso a informalidade, dando ao leitor a sensação de mais liberdade na expressão interna, inclusive liberdade de lembrar-se de assuntos que lhe incomodam, como a morte da irmã e o alcoolismo do marido, assuntos que evita tratar na frente de seu filho. Note-se:

hit by a car oh god I could never stand anything like that again like aileen but what if he's really sick cancer spinal meningitis leukemia brain tumor like john gunther's son or muscular dystrophy oh jeez kids his age get leukemia all the time radium treatments chemotherapy we couldn't afford anything like that but of course they just can't turn you out to die on the street can they and anyway he's all right all right all right you really shouldn't let yourself think (...) (KING, 2007. p. 155)

Já na edição brasileira, as partes grifadas evidenciam um tom pouco espontâneo, com abuso de advérbios terminados em "-mente" e um "naturalmente não podem em absoluto deixálo morrer", que me soa muito distinto do que é mais comum ouvir de um falante brasileiro. Uma sugestão mais natural para o trecho seria "mas é claro que não podem deixar ele morrer". No entanto, Albuquerque presenteia os leitores com a expressão bastante rotineira no Brasil "no meio da rua". Fosse mantido esse tom pela tradutora por pelo menos a maior parte do trecho, a oralidade teria sido bem representada em português. Abaixo, o trecho referido:

atropelada oh deus não poderia nunca aguentar alguma coisa assim novamente como aileen mas e se ele estivesse doente realmente realmente doente com câncer meningite leucemia tumor cerebral como o filho de john gunther ou distrofia muscular oh minha nossa crianças nessa idade têm 
leucemia radioterapia o tempo todo quimioterapia não temos condições de pagar coisas desse tipo mas naturalmente não podem em absoluto matá-lo no meio da rua e de qualquer forma ele está bem bem bem você não devia ficar pensando [...] (Tradução de ALBUQUERQUE, 1999, p. 91)

Um olhar atento aos monólogos de Jack em português também revela uma quebra na recriação da informalidade, retirando as marcações de oralidade. A frase "lembra como costumávamos dizer isso", em vez do mais oral "lembra como é que gente costumava dizer isso" ou mesmo "lembra como a gente dizia isso", retira a aparência espontânea do pensamento de Jack. Também parece desviar de um discurso informal a forma "angostura uísque", num trecho que clama por fluidez - o termo em português é mais técnico e pouco usual como o de língua inglesa "scotch whisky". A opção por "ti”, traduzindo "thee", no entanto, revela um esforço da tradutora em recriar a escrita antiga do texto em inglês, já que o pronome oblíquo "ti" tende a assumir um tom em desuso no português brasileiro falado ou escrito. Essa escolha creio ser um indício revelador de uma maior aceitação, na época, da formalidade do que da oralidade na narrativa. Afinal, a tradutora poderia simplesmente ter neutralizado o trecho na tradução, como fez com os trechos em que a língua oral fazia presença.

um ou dois drinques seria bom não me importo que o sol esteja se pondo em alguma parte do mundo lembra como costumávamos dizer isso, Al? gim e tônica bourbon com uma gota de angostura uísque com soda e coca-cola tweedledum and tweedledee um gole para mim um gole para ti os marcianos pousaram em algum lugar do mundo princeton ou houston, stokely on carmichael ou alguma merda de lugar afinal de contas é tempo de ser felize nenhum de nós está. (Tradução de ALBUQUERQUE, 1999, p. 439)

Em inglês, por contraste, não se notam quaisquer evidências de um trecho formal. As partes grifadas são bem coloquiais:

good just one or two would be i don't care sun's over the yardarm somewhere in the world remember how we used to say that al? gin and tonic bourbon with just a dash of bitters scotch and soda rum and coke tweedledum and tweedledee a drink for me and a drink for thee the martians have landed somewhere in the world princeton or houston or stokely on carmichael some 
fucking place after all tis the season none of us are . (KING, 2007, pp. $367 \mathrm{e}$ 368)

Já se a voz de Danny na edição brasileira for analisada, percebe-se uma fala muito polida para um garotinho de somente cinco anos (perceba o negrito), que talvez cause estranheza ao leitor brasileiro uma criança falar como a seguir:

Mamãe pensara mais e ele ficara debaixo de um medo constante de que ela pudesse arrancar a palavra de seu cérebro e concretizá-la pela boca. (Tradução de ALBUQUERQUE, 1999, pp. 60)

Compare com a versão original:

It had mostly been around his mommy that time, and he had been in constant terror that she would pluck the word from her brain and drag it out of her mouth, making it real. (KING, 2007, pp. 29 e 30)

Embora o trecho acima não tenha sido retirado de um diálogo ou monólogo, o leitor encontra-se diante da voz de Danny entremeada na narração. Toda vez que ocorre isso na obra, o leitor verá a utilização de vocabulário infantil ao lado de palavras mais formais. Na tradução, entretanto, não houve preocupação em misturar os registros, como se vê, com exceção da forma carinhosa "mamãe", e ainda há o uso do pretérito mais-que-perfeito sintético, reconhecidamente um traço muito formal da língua escrita (BRITTO, 2012, p. 96). Uma sugestão para o trecho, em que se tente recriar a oralidade e discurso infantil, seria "mamãe ficava pensando naquela palavra toda hora, e ele ficava apavorado pensando que ela tirava a palavra do cérebro e a puxava pela boca, deixando-a de verdade”. Nessa sugestão, que não pretendo ser a mais ideal, tento harmonizar a narração em terceira pessoa, mais formal na narrativa, com um modo de falar que se assemelhe ao de uma criança.

O contraste existente entre "o jeito de falar dos adultos" e "o jeito de falar das crianças", notado na edição dos EUA, é praticamente ineficaz em português, sendo omitidos todos os trocadilhos que Danny faz com as palavras que desconhece, tal como se segue na tabela comparativa: 
Tabela 3 - Comparação dos trocadilhos que Danny faz com as palavras

\begin{tabular}{cc}
\hline Texto fonte & Texto traduzido \\
\hline Expressão correta $\rightarrow$ Como percebida & Expressão traduzida sem tentativa de \\
por Danny & recriação \\
\hline Presidential Suite $\rightarrow$ "Presidential Sweet" & Suíte Presidencial (Tradução de \\
$($ KING, 2007, p. 65) & ALBUQUERQUE, 1999, p. 78) \\
\hline Ha Loo Sin Nation (idem, p. 31) & A-LU-CI-NA-ÇÃO (idem, p. 44)
\end{tabular}

Fonte: King (2007) e King (1999), tradução de Betty Ramos de Albuquerque.

O cerne da narrativa de The Shining, o que lhe dá vida e possibilita-lhe os tons de terror na narrativa (vide "Arrepios na narrativa"), o que a deixa mais sóbria e sinistra, é a percepção que se tem dos acontecimentos através do olhar e compreensão de Danny, a criança que é levada a enfrentar um mundo aterrorizante, mais até do que o mundo "real" que ainda está descobrindo. Se forem retiradas da narrativa praticamente todas as construções que representam modos infantis de se expressar e entender a realidade, como fez Albuquerque em 1977, obter-se-ia uma característica extremamente marcante apagada na tradução. Os leitores ficaram privados ao acesso a parte da potencialidade literária do texto.

Se for tomado o exemplo da expressão "REDRUM", que surge nas visões assombrando Danny (eternizada também pela versão cinematográfica de 1980, dirigida por Kubrick), percebe-se que Albuquerque optou por não traduzi-la, fazendo uma explicação em nota de rodapé toda vez que os adultos tentam explicá-la a Danny e quando o seu significado é revelado, junto aos momentos de tensão da narrativa - essa explicação da expressão que mais apavora a criança (e por extensão, faz vacilar o leitor que se vê dividido entre o pavor de Danny e as tentativas de explicação racional dos adultos) retira o momento de tensão da história. Em outras palavras, nesse exato instante o leitor precisa voltar sua atenção para uma nota de rodapé, perdendo a tensão de um ponto crucial da narrativa. Nesse momento, deixaria o leitor de ver pelos olhos de Danny e passaria a ver ante um olhar analítico como os adultos da trama.

Considerando a análise demonstrada em "3.1.3: Arrepios na narrativa”, da relevância de "REDRUM" para que os critérios da estrutura fantástica sejam cumpridos, estou quase convicta de que a ausência de qualquer tentativa de recriação da palavra em português contribui apenas para diminuir o efeito que gera. Minha crítica, sempre centra-se, portanto, nas consequências que o apagamento dos recursos literários acarreta à própria narrativa. 
A fim de ilustrar essa ideia, comparo o texto de King com a versão de Albuquerque:

\author{
'What things, Danny?' \\ 'I can't remember!' (...) All I can remember when I wake up is REDRUM.' \\ 'Red drum or red rum?' \\ 'Rum.' \\ 'What's that, Danny?' \\ 'I don't know.' (KING, 2007, p. 154)
}

Em língua portuguesa, foi feita uma nota de rodapé que explica o trocadilho em inglês, sendo mantido o termo em inglês:

— Que coisas, Danny?

- Não consigo me lembrar! [...] Tudo que me lembro quando acordo é REDRUM.

— Red drum ou red rum?

- Rum.

- O que é isso, Danny?

— Não sei. (Tradução de ALBUQUERQUE, 1999, pp. 188 e 189)

E quando Danny vê refletida no espelho a misteriosa palavra, revela-se seu significado com grande terror, pois o leitor descobre através do olhar da criança que a agora lê na parede e percebe o que quer dizer: "REDRUM" era o reflexo de "MURDER". Para um leitor que desconhece o termo em língua inglesa, no entanto, esta justaposição entre "MURDER" e "REDRUM" é ineficaz e não diz nada:

REDRUM

MURDER

REDRUM 
MURDER

*MURDER = ASSASSINATO. (N. da T.) (Tradução de ALBUQUERQUE, 1999, p. 404)

Para entender o trecho clímax da narrativa, o leitor brasileiro precisa dirigir-se a uma nota de rodapé, não sentindo a tensão à qual o leitor do texto fonte é sujeitado nesse trecho.

\subsection{Outros tempos, outra dimensão: a presença no sistema literário brasileiro atual}

Todavia, o texto da primeira tradução não é o mesmo ao qual os leitores brasileiros desejosos de usufruir a leitura de $O$ iluminado têm acesso hoje, no caso de optarem pelas versões disponíveis para a venda nas livrarias. Felizmente, parece que o tempo tem sido vantajoso para a obra no Brasil. Além de haver diversas edições desde seu lançamento, uma revisão mais importante foi feita em 2009, por Fátima Fadel e Héllen Dutra. Nela, nota-se uma mudança estratégica nas escolhas tradutórias dos diálogos de Danny, Hallorann, Wendy e Jack.

As alterações deram-se principalmente no campo da oralidade, feitas em oposição ao apego pela gramática normativa vista na tradução anterior. Agora Danny parece-se mais com uma criança de sua idade, com a fala ligeiramente mais natural, e os diálogos de seus pais e de seu mentor Hallorann parecem fluir com um pouco mais de espontaneidade.

Tal mudança revela-se facilmente se for notada a parte grifada a seguir no diálogo de Wendy com seu marido com a marca característica da língua falada - pronome do caso reto, enquanto na gramática padrão se esperaria um do caso oblíquo -, da nova estratégia, como a seguir:

Eu odeio elas - disse ela.

O quê... as vespas? (Tradução de ALBUQUERQUE, 2009, p. 160)

Também nota-se uma tentativa de se reproduzir informalidade e um pouco da língua falada em Hallorann. Observe como a mudança nesse aspecto se dá num diálogo com Danny: 
a) na versão de 1999, não há nada que indique alguma tentativa de se criar um discurso divergente do discurso padrão:

Este é alugado. O meu Bessie está do outro lado. Aquilo sim é um carro. Um Cadillac 50, e como roda! Pode ter certeza. Está guardado na Flórida porque é muito velho para estas subidas todas. Quer uma ajuda? (Tradução de Albuquerque, p. 54)

b) já na versão de 2009, é evidente que as revisores se preocuparam em reescrever o texto de modo a ressaltar mais a informalidade de Hallorann numa coversa com o menino Danny. Primeiro, omite-se o pronome demonstrativo "este", e a frase ficou reestruturada no modo mais simples (e mais oral) "é alugado", já que a narração já informara que estavam observando um carro. Em seguida, Hallorann se refere ao carro no feminino, numa maneira de demonstrar-lhe afeição, e as revisoras trocaram "lado" por "ponta", também mais informal e mais próprio de um discurso falado. Por último, a maior evidência de uma opção por deixar marcada, visível a oralidade: um pronome do caso reto ocupando o local que a gramática padrão restringe ao pronome oblíquo - "eu deixo ela", no lugar do neutro (nem com ênfase oral nem normativa) “está guardado". Há de se imaginar também que Albuquerque tenha traduzido de um modo neutro para evitar cair num formalismo exacerbado para um diálogo, mas ao mesmo tempo evitando a opção por marcar a língua falada. Veja:

É alugado. A minha Bessie está na outra ponta. Aquilo sim é um carro. Um Cadillac 50, e como roda bem! Eu deixo ela na Flórida porque é muito velha para estas subidas todas. Quer uma ajuda? (Tradução de Albuquerque, p. 109)

Já o caso de Danny, considero que foi a alteração mais expressiva na revisão:

a) no texto de 1999, os únicos indícios, no excerto abaixo, de que Danny é uma criança são os vocábulos “mamãe” e "papai”. Fora isso, o leitor não é capaz de distinguir a idade dos personagens somente com base na estruturação do diálogo. Observe:

— Está com sono? - perguntou Jack, tirando o cabelo da testa de Danny.

- Estou.

— Quer um copo d'água?

- Não...

$[\ldots]$

— Danny...? 
- Você não seria capaz de machucar mamãe, seria, papai?

- Nem a mim?

— Não. (Tradução de ALBUQUERQUE, p.82)

b) por outro lado, na edição de 2009, as revisoras Fátima e Héllen refazem esse diálogo de um modo que o leitor quase que "escuta" o pai e o filho conversando, mesmo que as marcas de oralidade apenas estejam nas falas de Danny. Ainda assim, a espontaneidade do trecho é recriada com êxito mediante o emprego de "tô", a forma mais oral e comum de "estou" no Brasil; a retirada de "você seria capaz de machucar" substituída pela forma mais sintética "machucaria", a inserção do "né", como elemento de reforçar a frase anterior, em vez do "seria"; e, por fim, a mudança de "nem a mim" pela expressão mais corriqueira e mais provável de ser escutada de uma criança "nem eu":

— Está com sono? — perguntou Jack, tirando o cabelo da testa de Danny.

- Tô.

- Quer um copo d'água?

- Não...

$[\ldots]$

- Danny...?

— Você não machucaria a mamãe, né, papai?

- Nem eu?

— Não. (Tradução de ALBUQUERQUE, p.171)

Verifico que a mudança realizada de certo não foi fortuita, vez que por todas as páginas do livro me deparo com um falar com mais reflexos da oralidade em Danny, talvez numa tentativa de se representar uma criancinha conversando com os adultos. Entretanto, não identifiquei mudanças substantivas nos fluxos de pensamento, nem nas confusões que Danny faz com as palavras.

Mas devo ressaltar aqui as possíveis razões a que se deve essa mudança para um tom mais oral na tradução. Após anos desde a primeira publicação, foi realizada uma alteração mais profunda, que pode não ter acontecido por qualquer motivação especial, somente a decisão de se revisar um texto antes de republicá-lo. Contudo, lançarei a hipótese de que houve a necessidade editorial de atualizar o texto e as revisoras optaram por uma nova forma de se traduzir com relação à oralidade e informalidade dos personagens.

Como o livro tem sido alvo do interesse do público ao longo de suas edições, talvez possam ter imaginado que a primeira tradução deixava suspensos alguns recursos literários, 
quando optara pelo caminho da gramática normativa. A revisão de 2009 pode ter sido então a oportunidade de tentar produzir uma versão mais interessante, mais criativa do ponto de vista literário. Após tantos anos da publicação, penso, já não haveria mais o risco de se entregar ao público um texto muito ousado, que pudesse ser facilmente rejeitado, em especial se tratando de uma obra com expectativa de ampla aceitação no mercado. Hoje já não haveria mais essa variabilidade de resultados inesperados, pois dificilmente a obra configuraria nas listas de mais vendidos das grandes livrarias nacionais (a não ser, talvez, se surgisse uma nova adaptação para o cinema, o que poderia ressuscitar o interesse do público em geral para a obra).

O público-alvo de $O$ iluminado concentra-se, creio, em leitores com interesse no sistema literário das obras do gênero fantástico e de horror e nos leitores que apresentam interesse específico na literatura de Stephen King. A possibilidade de se ousar mais nas opções de tradução torna-se mais viável, uma vez que o texto já se encontraria mais estabelecido junto ao sistema literário brasileiro. Afinal, o que justificaria a contínua publicação de um livro se o público não demonstrasse interesse em lê-lo ao longo do tempo?

Destarte, argumento que $O$ iluminado tem se firmado no sistema literário brasileiro e sua posição já não me parece ser tão periférica quanto na época de seu lançamento. Devido a uma posição que tende um pouco mais ao centro, ao menos do sistema de literatura de horror que integra, tornam-se possíveis alterações na estratégia de tradução - no caso, a recriação da oralidade nos diálogos, ainda que discreta.

Não obstante, questiono-me se de fato uma tentativa de marcar a língua falada traria consigo alguma vantagem em relação a uma tradução sem grandes divergências nos registros das vozes dos personagens, tal como demonstrei previamente ser o caso da primeira versão do texto de Albuquerque.

No capítulo seguinte, abordarei, com base numa seleção de estudiosos da tradução, a questão da recriação literária da oralidade nos diálogos e fluxos de pensamentos dos personagens, bem como me aprofundarei nas justificativas para uma tradução criativa, que trabalhe com a recriação das marcas de oralidade e de outros recursos estilísticos que se sobressaem na leitura de The Shining, em sua língua fonte. Acredito que uma tradução que venha a explorar as características literárias da obra poderá ser um critério que permitirá uma vida mais prolongada à obra no sistema literário brasileiro. 


\section{NOVA VIDA A UMA VELHA HISTÓRIA}

\subsection{Recriando o horror: rumo a uma tradução com sussurros, vozes e gritos}

É possível questionar se de fato a recriação da oralidade na literatura traria consigo alguma vantagem em relação a uma tradução sem grandes divergências nos registros das vozes dos personagens, tal como demonstrei no capítulo anterior (3.2.2 "Outra língua, outros sustos”) ser o caso da primeira versão do texto de Albuquerque. Abordo então a recriação literária das marcas da língua oral nos diálogos e fluxos de pensamentos dos personagens.

Pode-se criticar a tradução brasileira de $O$ iluminado, em especial antes da revisão de 2009, pela ausência dessa tentativa de se produzir diálogos e monólogos que poderia apresentar um retrato mais adequado dos personagens e das situações informais em que se encontram, da mesma forma como Kohan (2013, pp. 58 a 67) orienta a respeito da criação de diálogos literários, como discutido no primeiro capítulo.

Num texto de literatura, como afirma Azevedo (1998), pode-se fazer uma tentativa de criação de uma variedade literária (ou "dialeto literário", como sugere o autor) para mostrar que um personagem "fala" de modo diferente dos outros. É de fato uma criação, isto é, o autor escreve de maneira a não transcrever com exatidão científica a língua falada, mas imitá-la, sugerindo, por meio de formas lexicais e sintáticas, as nuanças que almeja conferir à voz personagem - desde um dialeto a um registro antiquado, de um sotaque a uma idiossincrasia idiomática. Essa criação é feita de tal forma que seja adequada à narrativa, sem pretender ser idêntica ao real. Em outras palavras,

representação estilizada da fala por meio de características não-padrões, regionais, sociais, ou até individuais. O dialeto literário simula a fala por meio da combinação de algumas características proeminentes para sugerir uma forma de fala que desvia da considerada padrão. Assim fazendo, dá maior importância à voz de certos personagens, contrastando-os com a fala de outros, ou com a voz do narrador, ou até com a voz do próprio leitor [...]. (AZEVEDO, p. 28) ${ }^{14}$

\footnotetext{
14 “ (...) a stylized representation of speech by means of nonstandard, regional, social, or even individual features. Literary dialect emulates speech by combining a few salient features to suggest a way of thinking considered deviant in relation to an accepted standard".
} 
Ressalte-se que a reprodução da língua falada na escrita não é "um discurso real, seja padrão seja qualquer outro, mas, na verdade, um artefato estilístico que o simule" (AZEVEDO, 1998, p. 28) ${ }^{15}$. Essa constatação dificulta ainda mais o trabalho do tradutor, posto que lida com construções artísticas, que envolvem não apenas o que foi dito, mas a forma como foi construído. Acerca da forma, Katharina Reiss (2000) considera que o aspecto artístico de determinada obra literária, isto é, a forma como a construção da escrita foi feita, é tão relevante para a decisão da estratégia de tradução quanto o conteúdo textual. Nas palavras da autora:

O autor faz uso de elementos formais, seja de modo consciente seja inconsciente, para um efeito estético específico. Esses elementos formais não exercem simplesmente uma influência no assunto em questão, mas transcendem-no para contribuir a uma expressão artística especial que é distinta no contexto e somente consegue ser reproduzida na língua alvo por meio de uma forma análoga de expressão. (2000, pp. 31 e 32) (Tradução $\operatorname{minha}{ }^{16}$ )

Desse modo, pode-se considerar que as marcas de oralidade em diálogos constituem um elemento formal e também artístico, distinguindo-se no contexto da obra.

Britto (2012, p. 67) demonstra mais especificamente o que seriam as marcas de oralidade numa narrativa. Segundo a perspectiva do autor, baseada nas ideias de Meschonnic e Jakobson, é primeiro necessário vir a entender o que seria a marcação num texto. Todos os recursos estilísticos que se distinguem ao longo de um texto seriam marcas específicas relevantes para a obra. Portanto, ao lidar com a transformação de um texto em outra língua,

todos aqueles elementos do texto original que um leitor nativo consideraria convencionais e normais devem corresponder, na tradução, elementos encarados do mesmo modo pelos leitores da língua-meta. Por outro lado, toda vez que o autor do original utiliza algum recurso inusitado, destoante, desviante, que chama a atenção do leitor - é o que estamos chamando de "marcado" -, cabe ao tradutor utilizar, na tradução, algum elemento que suscite no leitor nativo da língua-meta o mesmo grau de estranhamento, nem

\footnotetext{
15 "are not real speech, standard or otherwise, but rather a stylistic artifact that emulates it".

16 “[...] the author makes use of formal elements, whether consciously or unconsciously, for specific esthetic effect. This formal elements do not simply exercise an influence over the subject matter, but go beyond this to contribute a special artistic expression that is contextually distinctive and can be reproduced in target language only by some analogous form of expression."
} 
mais, nem menos, que a passagem original provocaria no leitor da línguafonte. (idem)

São as marcas que saltam aos olhos do leitor, e é por elas que reage com familiaridade ou com estranhamento, ao que não caberia ao tradutor modificar essa relação do leitor da tradução com as marcações (idem). Para ilustrar esse conceito, observe um exemplo do monólogo já citado de Wendy:

hit by a car oh god I could never stand anything like that again like aileen but what if he's really sick cancer spinal meningitis leukemia brain tumor like john gunther's son or muscular dystrophy oh jeez kids his age get leukemia all the time radium treatments chemotherapy we couldn't afford anything like that but of course they just can't turn you out to die on the street can they and anyway he's all right all right all right you really shouldn't let yourself think (...) (KING, 2007. p. 155)

Nesse exemplo, as suas marcas características seriam a ausência de pontuação padrão, a escrita não convencional "jeez", no lugar de "Jesus", palavras sempre iniciadas por minúsculas etc. Fosse um tradutor apagá-las na língua alvo, isto é, fazer uma tradução sem o objetivo de ater-se à forma do texto, somente ao seu conteúdo, ele obteria uma versão com pontos e vírgulas em seus devidos lugares, como prescreve a gramática normativa, palavras escritas como nos dicionários, maiúsculas iniciando frases e nomes próprios etc.

As marcas citadas foram respeitadas por Albuquerque (1999), com a aparência "gráfica" mantida, ainda que se argumente que outras marcas presentes não tenham sido recriadas. Eis a versão da tradutora:

atropelada oh deus não poderia nunca aguentar alguma coisa assim novamente como aileen mas e se ele estivesse doente realmente realmente doente com câncer meningite leucemia tumor cerebral como o filho de john gunther ou distrofia muscular oh minha nossa crianças nessa idade têm leucemia radioterapia o tempo todo quimioterapia não temos condições de pagar coisas desse tipo mas naturalmente não podem em absoluto matá-lo no meio da rua e de qualquer forma ele está bem bem bem você não devia ficar pensando [...] (p. 91, grifo meu) 
Em comparação com o texto em inglês, nota-se que a tradução está algo mais formal (como nos trechos grifados), com menos evidências da oralidade em sua recriação, o que lhe conferiria um caráter mais fluido, com aparência de pensamento, como na escrita de King. Pode-se dizer que nem todas as marcas foram, então, recriadas pelo tradutor. O que foi deixado de lado - o aspecto familiar que o leitor teria ao se deparar com a naturalidade do pensamento - transforma-se em uma formalidade maior. Essa "naturalidade do pensamento" fica comprometida também pela tradução mais literal de expressões como "oh god", que se torna um nada comum em português "oh deus". Talvez o mais propício para uma mimetização mais próxima da realidade seria um "ai, meu deus" (ou quem sabe um "valha me deus", embora aqui estivesse dando uma coloração mais regionalizada). Albuquerque, no entanto, fez bem em traduzir "on the street" para "meio da rua", mais comum em português, e "jeez" pela expressão enraizada em português brasileiro "minha nossa", nesse trechinho. Porém não levou adiante a estratégia de uma tradução mais marcada por informalidade.

Steiner (apud Paes 1995, p. 43) dá ao fenômeno da língua que só se materializa no terreno das traduções, o nome de "idioma-centauro", um idioma que não é nem próprio da língua do texto fonte nem da língua meta. Algo produzido exclusivamente para o contexto da obra traduzida, que não é de lá nem de cá, mas busca a aproximação entre as duas línguas "como que a meio caminho da língua de partida e da língua de chegada, muito mais perto desta evidentemente, mas contaminando-a, sem desfigurá-la, com o espírito da outra". O tradutor faria seu idioma-centauro utilizando-se principalmente de decalques, morfológicos e sintáticos, que imprimissem conceitos e inovações na língua alvo presentes no texto de origem. Em outras palavras, seria a justificativa de "sublinhar [na tradução] uma deliberada violação do código normal da língua por um poeta inovador" (idem, p. 45). Se o tradutor não tomar cuidado, poderia marcar o não marcado por marcações em português, o que desandaria no que Paes (1995, p. 45) designa de "sobretradução".

Essa estratégia "centauro" tornar-se-ia mais bem sucedida percebendo como as marcas originais são empregadas na tradução visando o mesmo efeito no leitor, ou seja, marcando o marcado pelo marcado. Tal recriação dos recursos estilísticos tentaria aproximar o leitor da cultura do texto fonte utilizando-se de elementos característicos da língua meta, juntamente com outros que não existem nela. Essa escrita seria própria das traduções, o que tornaria a atividade essencialmente criativa e única. 
Ao considerar que a escrita traduzida é de fato um processo criativo, estaria dando-lhe um caráter menos submisso em relação ao texto fonte. Explico melhor. Durante parte significativa da história da tradução, problematizou-se a infidelidade que as traduções invariavelmente teriam com relação à obra fonte ${ }^{17}$. Seu caráter manipulador, infiel e perturbador da "sacralidade" 18 do texto em língua estrangeira provocou um sem fim de analogias que enfatizam a sua inferioridade e que postularam, como diz Berman (2002, p. 15) o "drama do tradutor", que está sempre dividido entre a fidelidade e à traição ${ }^{19}$. No entanto, estudiosos da atividade tradutória têm notado que o tradutor seria também capaz de fazer aparecer na tradução aspectos, por assim dizer, "ocultos". Seria, portanto, um processo de ganhos e perdas, compensando com criatividade aqui o que se perdeu ali, processo o qual Berman diz

que ocorre em toda tradução, mesmo acabada. O que se pode chamar de seu caráter "aproximativo". Afirmando, pelo menos implicitamente, que a tradução "potencializa" o original, [...] ganhos e perdas, aqui, não se situam no mesmo plano. Em outras palavras: em uma tradução, não há somente uma certa porcentagem de ganhos e perdas. Ao lado desse plano, inegável, existe um outro, em que alguma coisa do original aparece e que não aparecia na língua de partida. A tradução faz girar a obra, revela dela uma outra vertente. (idem, p. 21)

A recriação na língua alvo já não seria apenas um mal necessário, mas permitiria elevar (pelo menos um pouco) o status da tradução. Um texto traduzido não seria mais percebido exclusivamente como inferior, mas com uma capacidade de enriquecer tanto a língua alvo, como o próprio sistema cultural em que se insere. Segundo esse ponto de vista, entendo que a relação com o original é de reciprocidade e diálogo (BERMAN, 2002, p. 16), não de hierarquização. De certo que se pode criticar traduções e compará-las com o texto fonte ${ }^{20}$ e

\footnotetext{
17 "Faço referência aqui a alguma coisa que não pode deixar de ser evocada: a condição ocultada, reprimida, reprovada e anciliar da tradução [...]". (BERMAN, 2002, p. 15)

${ }_{18}$ Meschonnic (apud Paes, 1995, p. 46) denuncia "o quanto há de ideológico no pressuposto da inferioridade do texto traduzido em relação ao original e no consequente menosprezo de correntes da sacralização da literatura por um imperialismo cultural eurocêntrico interessado em manter o primado do metropolitano sobre o colonial, do central sobre o periférico".

${ }^{19}$ Uma ressalva: não é a pretensão desta dissertação trazer o debate acerca da natureza da tradução ou das dicotomias fidelidade $\mathrm{x}$ infidelidade e estrangeirização $\mathrm{x}$ domesticação que permeiam a discussão sobre $\mathrm{a}$ atividade do tradutor. Considero que era somente preciso mencionar brevemente a problemática da relação entre o texto fonte e o texto traduzido para embasar a argumentação sobre tradução criativa.

${ }^{20}$ É importante destacar que não acredito ser possível uma crítica aos aspectos literários da tradução sem o cotejo com um original - afinal, creio que uma tradução somente será uma tradução se há a noção de que é um texto que partiu de algum texto prévio. Poder-se-ia, claro, criticar a presença de obras traduzidas numa sociedade, sua influência na literatura, a recepção das obras etc.
} 
apontar qual das duas sobressai em aspectos literários em relação à outra, mas já não há a expectativa (pelo menos no campo teórico da tradução) de que a tradução sempre será obrigatoriamente ruim e impossível, ainda que possa ser frágil. Benjamin (2008, p. 93), estabelece uma analogia que me parece resumir bem essa questão:

Tal como os cacos de um vaso, para se poderem reajustar, têm de encaixar uns nos outros nos mais pequenos pormenores, embora não precisem de ser iguais, assim também a tradução, em vez de querer assemelhar-se ao sentido do original, deve antes configurar-se, num acto de amor e em todos os pormenores, de acordo com o modo de querer dizer desse original, na língua da tradução, reconhecíveis como fragmentos de uma língua maior, tal como os cacos são os fragmentos de um vaso inteiro.

Não obstante, há também o "traducionês", termo cunhado por Paes (1995, p. 45), como sinônimo de idioma-centauro, ao qual tomo emprestado e ofereço novo e diferente sentido aqui: uma língua da tradução também, mas que, diferente da língua-centauro, a recriação das marcas não seria seu norte. $O$ texto resultante seria igualmente característico das traduções, mas seria algo mais próximo da língua estrangeira, mais literal e menos criativo. Creio, assim, que a primeira tradução de The Shining traz consigo inúmeros elementos desse "traducionês", que resultam num distanciamento do leitor em relação ao universo dos personagens, uma relação que é mais estreita no caso dos leitores de língua inglesa. Por exemplo, o monólogo de Wendy citado anteriormente (ALBUQUERQUE, 1999, p. 91) abusa de advérbios finalizados em “mente" ("novamente", "realmente" e "naturalmente"), menos usuais em nossa língua, utiliza a interjeição "oh" em vez de "ai", que seria mais própria da língua oral brasileira e utiliza uma ênclise ("matá-lo"), quando na língua oral tende a ser mais comum a próclise ou, principalmente se tratando do português do Brasil, a troca do pronome oblíquo pelo pronome do caso reto ("matar ele").

Tendo sempre em mente esse processo da tradução como atividade criativa, retorno agora às marcas de oralidade. De acordo com Britto (2012, pp. 81 e 82), a oralidade na escrita tende a ser, ao longo da história da literatura, mais evidente em textos na língua inglesa do que na portuguesa.

Os diálogos na narrativa em inglês parecem-se mais com a fala das pessoas no cotidiano e isso se reflete tanto na sintaxe quanto no léxico e na própria ortografia, que pode se desviar 
daquela prescrita costumeiramente. A prática é deveras comum e parece haver preocupação maior em fazer diálogos distintos das formas mais padronizadas de escrita.

Em português, a oralidade tende a ficar menos aparente, pois em geral se nota um apego às normas gramaticais. Certo que há exceções notáveis, como menciona Britto (idem, p. 83): modernistas como Nelson Rodrigues e autores mais contemporâneos recriam vozes que bem se poderia escutar numa conversa qualquer no meio da rua. Já no caso das traduções brasileiras, parece que se ouve os personagens sempre muito mais formais do que a forma espontânea como se fala corriqueiramente, mesmo quando os personagens "falam" muito mais coloquiais nas linhas da narrativa de origem ${ }^{21}$.

Britto (idem), propõe uma explicação para essa divergência:

creio que o fenômeno se deva às maneiras opostas como os falantes do inglês e do português encaram (ou, ao menos até recentemente, encaravam) seus respectivos idiomas. De modo geral, para o anglófono, a língua pertence aos seus falantes: a função dos dicionários é registrar as palavras que vão surgindo, colhidas pelos jornalistas, romancistas e contistas, pelos roteiristas de cinema e televisão. Do mesmo modo, as gramáticas inglesas se dedicam mais a registrar do que a julgar.

O autor também toca num ponto crucial: embora em língua inglesa exista uma norma culta, ela tende a ser percebida como um instrumento "que se aplica apenas aos usos mais formais da língua: ao ensaio, ao compêndio erudito, mas não à fala dos personagens dos romances e filmes" (idem).

Pelo menos até meados da década de 1960, Britto (idem, p. 84) pontua que a relação dos brasileiros perante seu idioma seria uma pautada pelo desejo de se preservar o português dos próprios falantes, como se fosse algo valioso que se corrompesse à mínima variação. Seria também uma atitude algo racista e xenófoba, ignorante de questões linguísticas, que não admitia os desvios do padrão introduzidos "por brasileiros, por analfabetos, por imigrantes africanos e levantinos e italianos". A introdução de novos termos, de novas formas de pronúncia, de sintaxe

\footnotetext{
${ }^{21}$ Essa tendência foi debatida no segundo capítulo, mas parece-me que ganha espaço entre nós uma maior abertura à recriação da oralidade nos diálogos da ficção, do mesmo modo como Britto (2012, pp. 84 a 86) considera.
} 
diferente era vista como uma grave ameaça ao futuro da língua portuguesa - sempre considerada mais de lá de Portugal do que de cá, terras tupiniquins.

Britto (idem, p. 86) conclui que a consequência "dessa visão tradicionalista" foi tornar a tarefa de produzir diálogos verossímeis uma árdua batalha para os escritores (e por extensão, pode-se inferir, para os tradutores e as políticas editoriais). Todavia, cada vez mais no Brasil abre-se a possibilidade de os profissionais envolvidos exercerem a criatividade em prol de um "efeito de verossimilhança" nos diálogos da ficção, como mencionado no início deste capítulo ser a proposta de Azevedo (1998). Explico a seguir, como Britto também faz coro às ideias daquele autor, embasando ainda mais meu ponto de vista de que uma tentativa de reconstrução dos recursos para dar voz aos personagens pode sim ser muito benéfica para uma tradução que marque as particularidades tal como no original.

Segundo Britto, para se obter o "efeito de verossimilhança", não basta transcrever os diálogos exatamente como se faz nas pesquisas linguísticas, o que desandaria num problema muito maior: a fala real é truncada, repleta de pausas e lacunas, pois leva em conta os gestos e expressões faciais dos falantes, o que tornaria a leitura um tanto quanto incômoda, já que não conta com a visualização da interação entre os personagens. Assim,

o trabalho do ficcionista e do tradutor de ficção é criar artificialmente - através dos recursos da arte de escrever diálogos - a impressão de que o que se está lendo é a fala real de um personagem. Para que o efeito funcione, o diálogo não deve parecer estranho ao leitor - isto é, não deve se afastar demasiadamente de algumas convenções da linguagem escrita; ao mesmo tempo, como já vimos, não deve se ater demais a elas [...]. (BRITTO, 2012, p. 87)

Para que o tradutor consiga reproduzir o efeito verossímil em português, então é necessário recriar algumas características da língua falada no Brasil. A essas características, Britto dá o nome, já mencionado aqui diversas vezes, de marcas de oralidade. As marcas visam transmitir a naturalidade dos falantes nos mais variados registros da língua oral - perpassando desde as marcas comuns ao português brasileiro como um todo - caracterizando, portanto, a coloquialidade -, até as marcas específicas de determinados segmentos da sociedade e aquelas correspondentes às faixas etárias (idem, p. 88). 
Por conseguinte, a leitura dos diálogos traduzidos na ficção também levará em conta as implicâncias de uma variação não padrão no contexto da trama e o aspecto artístico decorrente do uso não padrão. Porém, alguns problemas surgem no caso de uma tradução. A simples substituição de uma tentativa de escrita de uma variação não padrão por outra pode não ser capaz de abranger todas as conotações do texto de partida, e talvez essa não constitua uma substituição neutra, isto é, ela acrescentaria conotações não existentes no texto fonte.

Azevedo (1998, p. 42), ciente dos riscos decorrentes de uma tentativa de tradução de uma variação não padrão, que poderiam acarretar, entre outras coisas, em má interpretação de uma variação sociolinguística, ainda assim considera que é fundamental que seja feita uma tentativa. De fato, segundo o autor, “o discurso não padrão não é apenas um modo alternativo, opcional de dizer a mesma coisa: antes, ele marca os personagens que o utilizam e afeta suas relações mútuas de um modo que a língua padrão é incapaz de replicar"22.

Afinal, sabe-se que a atitude do falante perante a língua não é atividade neutra. De acordo com Calvet (2002), "existe todo um conjunto de atitudes, de sentimentos dos falantes para com suas línguas, para com as variedades de línguas e para com aqueles que a utilizam, que torna superficial a análise da língua como instrumento”. Portanto, cabe aqui considerar que a escolha por identificar determinado personagem literário com a voz caracterizada por marcas que pretendem simular outra língua ou variedade linguística visa chamar a atenção do leitor para determinadas atitudes que a variedade linguística em questão desperta nos falantes.

A ausência das marcas de oralidade nos textos de $O$ iluminado publicados antes da revisão de 2009 revela como características do texto de partida desaparecem simplesmente por se adotar a padronização das falas de acordo com a gramática normativa. Sem que o tradutor leve em conta as situações sociais que a fala dos personagens traz à tona, as escolhas do profissional produzem um texto cujas nuanças originais apagam-se e não permitem ao leitor da tradução identificar o contexto da narrativa com mais precisão.

Embora os diálogos na ficção não sejam uma representação fidedigna da realidade, eles são um simulacro de uma realidade latente nas marcas de oralidade que o autor da obra escolhe para dar voz aos personagens. Sempre sujeita a críticas, a criação de um "dialeto literário" (AZEVEDO, 1998) confere, todavia, algo da complexidade existente no texto de partida que

\footnotetext{
22 "Nonstandard speech is not just an alternate, optional way of saying the same thing: rather, it marks the characters using it and affects their mutual relationships in a way that standard language cannot replicate."
} 
emprega traços da língua falada na escrita. Segundo Wekker e Wekker (1993), para lograr êxito em tal tarefa - isto é, obter uma tradução de uma variedade não padrão em que "se percebe mais semelhanças entre a língua do texto fonte e a variedade da língua alvo escolhida" ${ }^{23}$ - o tradutor deveria "estudar a função do texto da língua fonte na cultura da língua fonte e em seguida tentar encontrar um equivalente tradutório na língua alvo" ${ }^{\text {24. }}$

Para tanto, considero que a classificação das marcas de oralidade que Britto (2012) propõe para a recriação dos diálogos seria de grande valia aos tradutores que se deparam com a oralidade na narrativa e não sabem como proceder. A seguir, confrontarei a versão publicada de $O$ iluminado (1999) sem qualquer marca de oralidade com a tradução proposta por Filgueiras, Henrique e Reis (2011), cujo objetivo foi recriar a oralidade de Stephen King, pautando-se, para tanto, da proposta de classificação das marcas de oralidade elaborada por Britto $^{25}$.

\section{2 "E se?": a proposta de uma nova estratégia de tradução para a obra}

No ano de 2011, três alunas da Universidade de Brasília propuseram a si mesmas o desafio de retraduzir The Shining (KING, 2007) para o projeto final de graduação, com a orientação da professora doutora Alessandra de Oliveira Harden e do professor Ofal Fialho. As jovens pretendiam renovar a tradução mediante estratégias para reelaborar as marcas de oralidade que existiam no original e que foram apagadas na tradução brasileira, como já demonstrado anteriormente. Um dos principais argumentos para a elaboração de uma nova tradução era que a ausência das marcas de oralidade na publicação da editora Objetiva interferia de modo negativo na caracterização do texto traduzido como literatura fantástica, segundo a análise estruturalista de Todorov (1992), que já foi debatida no segundo capítulo.

Vale ressaltar que não pretendo neste espaço oferecer uma crítica prescritiva, de como deveria ter sido feita a tradução de The Shining. Pretende-se, por outro lado, expor diferentes escolhas tradutórias que têm como objetivo colocar em evidência aqueles traços da língua

\footnotetext{
23 “" [...] there is perceived to be more linguistic and sociological similarity between the Source Language text and the Target Language variety chosen."

24 "to study the function of the Source Language text in the Source Language culture, and then to make a serious attempt at finding a translational equivalent in the Target Language."

${ }^{25}$ A obra de Britto que versa sobre os diálogos na ficção ainda não fora lançada quando da publicação do projeto final de graduação das autoras, mas, para fazer a tradução, elas se basearam no material que Britto usara num evento de tradução e lhes foi gentilmente cedido pelo autor (FILGUEIRAS; HENRIQUE; REIS, 2011, p. 13).
} 
falada que conferem um caráter estilístico e relevante para o desenvolvimento da narrativa, sem jamais tê-las como "superiores", apenas diferentes, embora a argumentação lhes seja favorável. Afinal, compreendo o laborioso processo que envolve a publicação e divulgação e aceitação do texto no sistema alvo, no caso, o Brasil, e que, no trabalho de conclusão de curso em questão, as autoras da dissertação gozavam de liberdade acadêmica para realizar determinadas opções tradutórias - nem sempre viáveis do ponto de vista editorial para as traduções publicadas no Brasil.

Sob um enfoque crítico dos problemas advindos do apagamento das marcas de oralidade, concentro-me numa análise da recriação da oralidade fingida nos diálogos dos personagens de The Shining, elaborada pelas autoras do projeto final com o objetivo de fazer o leitor "obter uma compreensão mais completa da obra e [adentrar] em sua atmosfera de suspense" (FILGUEIRAS; HENRIQUE; REIS, 2011, p.157).

Para a tradução criativa que pretendiam, as autoras basearam-se, na época, em material cedido por Britto (2011), apresentado pelo autor num evento de tradução na Unesp, em 2009, sobre diálogos na ficção e como o tradutor pode marcar a oralidade dos personagens. No ano seguinte, o autor desenvolveu o mesmo assunto na obra "A tradução literária", a qual preferi adotar aqui para analisar a fala em linhas dos personagens de $O$ iluminado, na recriação das alunas de graduação. (FILGUEIRAS; HENRIQUE; REIS, 2011, p. 13), posto que nela o autor ampliou mais os conceitos que abordara na palestra concedida em 2009.

Antes de voltar-me a cada uma das marcas de oralidade especificamente, começo por uma análise do efeito da informalidade, num sentido mais amplo, dos personagens - efeito este que é alcançado graças aos recursos de criação de oralidade. No caso de Jack, pai e marido temperamental, que se deixa levar pelos delírios malignos instilados pelo sinistro hotel Outlook, quanto mais passa a viver na realidade paralela, mais ele permite que a raiva domine seus pensamentos e mais seu discurso apresenta xingamentos carregados de repulsa, dirigidos a sua própria família, como no trecho em língua inglesa:

I'll find you, you goddam little whoremastering RUNT! (KING, 2007, p. 465 , grifo meu) 
No segundo capítulo comentei a respeito de falas de Jack, quando verifiquei uma tradução pautada mais pela formalidade das normas gramaticais do que pelo tom pesado da fala de Jack. Abaixo, as autoras tentaram recriar algo mais característico de alguém que se expressa com raiva, em português brasileiro:

Eu vou te achar, seu pirralhinho desgraçado filho de uma puta! (FILGUEIRAS; HENRIQUE; REIS, 2011, p. 142, grifo meu)

Nessa linha, noto que a utilização do pronome reto "te" e a escolha lexical de "pirralhinho" e "filho da puta" foram essenciais para o um efeito oral e carregado de raiva. Agora compare com a primeira versão de Albuquerque, que apresenta um tom excessivamente formal - e em total acordo com as gramática padrão -, num momento de tensão:

Vou alcançá-lo, seu maldito fedelho. (KING, 2009, p. 463, grifo meu)

Em outro momento, as autoras tentaram mimetizar a espontaneidade de Jack alterando a ordem dos xingamentos, o que resultaria numa leitura em que se "ouve" mais a voz do personagem, do que se fosse mantida a estrutura sintática usual em língua inglesa ("shut the fuck up and kill them"):

Cale a boca, porra! Mate as vespas! (FILGUEIRAS; HENRIQUE; REIS, 2011, p. 142, grifo meu)

Pois se em inglês não havia a preocupação com uma fala formal, há de se imaginar que o leitor no Brasil não se devesse também se deparar com um discurso polido. Não é assim que se fala - e se pensa - quando não há ninguém ouvindo e quando se está em casa, em ambiente informal; pelo contrário, nessas situações, as pessoas falam e pensam sem preocupação com regras normativas. Portanto, seria mais interessante que a tradução evitasse marcar essa distância entre língua oral e língua escrita, tão notável nas primeiras edições do português brasileiro. Estou convicta de que é possível uma alternativa a esse abismo. Ainda mais numa 
obra em que o sinistro, o grotesco, o obscuro são tema central da obra, em que os personagens reagem muitas vezes de forma instintiva, deixando-se levar por emoções primitivas, como o medo e a agressividade. Não é natural que nesse ambiente cruel, em que se luta para manter a sanidade e sobreviver, Jack, Wendy, Danny e Hallorann estivessem preocupados - se falassem português - em não variar a pessoa de tratamento ou em usar um pronome oblíquo como objeto direto.

Foi com isso em mente que as referidas autoras propuseram uma nova tradução. Para embasar a escrita da tradução, elegeram como fonte a classificação de marcas de oralidade que Britto (2011) lhes enviara por correio eletrônico. Assim, poderiam dar um tratamento mais informal às falas dos protagonistas da história, que seria compatível com o horror que paira em suas vidas e lhes impulsiona a uma corrida para desvencilharem-se das entranhas do hotel Overlook.

Britto sugere aos tradutores que adotem marcas de oralidade com tendência a serem reconhecidas com facilidade por brasileiros de todas as regiões. Para driblar as mais variadas marcas dialetais que poderiam causar estranhamento nos leitores de uma região distinta daquela em que se baseiam os coloquialismos na escrita adotados pelo tradutor, Britto propõe que se embase na língua falada comumente adotada na televisão aberta, que é bem difundida pelos rincões do Brasil: o modo de falar do eixo Rio de Janeiro - São Paulo. Embora não considere que essa atitude seja perfeita, ainda assim a considera a mais recomendável, posto que marcas muito, diga-se, "carregadas no sotaque", poderiam ser rejeitadas pelo público ledor (BRITTO, 2012, p. 90 a 92), e apesar de um baiano do interior, por exemplo, não falar como um carioca ou paulistano, ainda assim ele já está acostumado a ouvir essa forma oral.

As marcas de oralidade descritas pelo autor dividem-se em três grupos: marcas fonéticas, lexicais e morfossintáticas. As primeiras seriam utilizadas com mais frequência em língua inglesa do que na portuguesa, sendo que, no Brasil, os textos costumam apresentar somente as formas reduzidas de "para", "não é”, "está" e "estava", as quais, respectivamente: "pra”, "né”, “tá" e "tava”. Ao tradutor seria recomendável ater-se a essas quatro, a fim de evitar estranhamento excessivo no leitor ("tô" poderia bem ser outro exemplo). Já as marcas lexicais, seriam coloquialismos que já constituem o vocabulário reconhecido pelos falantes e não são apenas gírias temporárias fadadas ao esquecimento em poucos anos. Um exemplo seria o verbo "curtir", que qualquer brasileiro não teria dificuldade em reconhecer (ainda mais depois do advento do botão "curtir", de uma certa rede social). É um verbo, no entanto, informal, pouco 
provável de ser encontrado num texto acadêmico sobre o comportamento de animais - "os papagaios curtem acerolas" seria uma sentença algo estranha aos olhos do leitor de literatura científica. Por fim, há as marcas morfossintáticas, que, segundo Britto, seriam as mais eficazes em transmitir o efeito de verossimilhança da oralidade ao leitor. Essas marcas não estariam, no geral, restritas aos falantes do eixo Rio - São Paulo, mas seriam notadas no falar dos brasileiros de todo o país, o que lhes confere vantagem em relação às outras duas, que variam muito de local para local. Além disso, o autor elenca várias dessas marcas como atemporais, isto é, não seriam específicas de determinada época, mas podendo ser traçadas há muitas décadas e até há séculos (idem, pp. 93 a 96$)^{26}$.

Comparando as soluções do projeto final de Filgueiras, Henrique e Reis (2011) com a análise das marcas de oralidade de Britto, em "Tradução literária (2012), demonstrarei as marcas morfossintáticas eleitas por elas para recriar o efeito de oralidade na narrativa, como elas se comportam na retradução, bem como comentários acerca das soluções adotadas:

a) colocação pronominal:

Nas palavras das autoras,

a colocação pronominal e a concordância são algumas das características mais marcantes da oralidade no cotidiano. Como as regras do português brasileiro falado nem sempre coincidem com as regras da língua escrita, usamos a próclise em muitos casos onde o correto seria a ênclise, ou até mesmo a mesóclise, e misturamos o uso da segunda pessoa do singular com a terceira pessoa do singular. A predominância da tendência para a próclise no português brasileiro se dá porque "na pronúncia do Brasil, as formas pronominais oblíquas não são completamente átonas; são, antes, semitônicas" (CEGALLA, 2000, p. 495). (FILGUEIRAS; HENRIQUE; REIS, 2011, p. 59)

Britto (2012, p. 101), acerca do assunto, recomenda que o tradutor siga o "seu ouvido" quando tiver de decidir a posição do pronome clítico, uma vez que existe a contradição da

\footnotetext{
${ }^{26}$ Acredito que o autor está se baseando nas características gramaticais do português falado no Brasil como um todo, numa perspectiva da Linguística. Todavia, não é meu objetivo aqui fazer uma análise linguística das marcas de oralidade comuns a todos falantes nativos do português do Brasil, tampouco foi o objetivo de Filgueiras, Henrique e Reis (2011), quando da sua proposta de retradução, tampouco foi o de Britto em suas considerações sobre a tradução de diálogos. Por tal razão, vou me ater tão somente à classificação de Britto (2012), tendo em vista que a oralidade na escrita é sempre ilusória e jamais pretende ser a perfeita transcrição da língua, e, para almejar meu objetivo, de certo que a classificação desse tradutor carioca é, além de suficiente, muito satisfatória.
} 
norma culta e da fala espontânea do brasileiro. A fim de um efeito convincente, deve-se "ler em voz alta a passagem, com a entoação natural, e deixar que seu ouvido determine a forma mais usada. Na grande maioria das vezes, é a forma proclítica” (idem). Outra tendência no Brasil, prossegue ele, é a supressão do pronome em orações como "O João casou”, ao invés de "O João se casou".

Posso demonstrar alguns exemplos em que foi possível notar a tentativa das autoras da retradução de The Shining de recriar marcas de oralidade com a presença de próclises. Em dado momento, Jack diz que "I'm surprised Al didn't tell you. I've retired", o que foi transformado, em português, em "Estou surpreso que o Al não tenha te falado. Me aposentei” (FILGUEIRAS; HENRIQUE; REIS, 2011, p. 60). Note-se que os pronomes "te" e "me" estão na posição de próclise. Principalmente com relação à segunda oração, o mais correto e recomendável seria “Aposentei-me". Mas quem falaria dessa forma polida, ainda mais quando se sabe que Jack referia-se à "aposentadoria" da época de suas bebedeiras, numa brincadeira? Caso se quisesse que essa a fala expressasse ainda mais a informalidade, numa nova revisão, sugeriria a opção: “Tô surpreso que o Al não te contou. Eu me aposentei”, que contaria também com uma marca de oralidade fonética "tô" e com o "uso redundante do pronome sujeito" (idem, pp. 100 e 101), no caso, o pronome "eu" no início da frase, marcando um sujeito que já é óbvio ao leitor - outra característica pronominal da oralidade que diverge das prescrições da gramática padrão.

b) concordância:

"O sistema de pessoa-número e formas de tratamento" e "o uso do pronome do caso reto na posição de objeto" são classificações de Paulo Henriques Britto (2012) para fenômenos recorrentes no português brasileiro. Entretanto, o autor alega que o primeiro "é uma das poucas marcas que não são uniformes em todo o território brasileiro, admitindo muita variação regional" (idem, p. 97), mas para os fins almejados, elege o dialeto do Sudeste para descrever o sistema pessoa-número e formas de tratamento (pelo motivo, já comentado, de adotar uma variação regional reconhecível ao redor de todo país).

Assim, o "sistema tradicional" prescreve, "tu" (segunda pessoa do singular), designando um tratamento íntimo, "o (a) senhor(a)", como forma deferencial e "você" para um tratamento neutro. O autor explica que, quando usado "senhor" ou "você", as formais verbais e pronominais corresponderiam à terceira pessoa do singular. Contudo, 
no Sudeste brasileiro, [...], desapareceu a oposição entre a forma íntima e forma neutra - apenas o caso deferencial continua se distinguindo da forma não marcada - houve uma mistura das formas de segunda e terceira pessoa do singular. O pronome reto quase sempre é "você", embora "tu" apareça ocasionalmente em contextos muito informais; o verbo vai quase sempre para a terceira do singular; o possessivo é ora "seu", ora "teu"; o objeto direto ou indireto é quase sempre "te". (BRITTO, 2012, p. 98)

Ao tradutor caberia decidir o quanto que o contexto tende à informalidade, tendo a sua disposição diversas formas de combinação. Cito duas: ou (a) mistura as pessoas (utilizando no discurso do mesmo personagem "você", "te", "teu" e "seu”) ou (b) procura neutralizar essa característica utilizando o "você" e alternativas para o pronome oblíquo "lhe", que seria o prescrito para essa forma, mas que normalmente os falantes não empregam. Consigo imaginar brevemente alguns exemplos que esclarecem essas duas estratégias: (a) "você me ligou? Te liguei de volta, mas a ligação não completou" e (b) "você me ligou? Liguei, mas a ligação não completou".

Agora prossigo a análise de como Filgueiras, Henrique e Reis (2011) utilizaram-se do "sistema de pessoa-número e formas de tratamento" nos diálogos dos personagens (grifo meu):

- Há um instante atrás eu disse que você trancou a porta do banheiro. Mas não foi isso, não é? O Tony trancou a porta.

— Não, senhor. O Tony não podia trancar a porta porque ele não é real. Ele queria que eu trancasse, e foi o que eu fiz. Fui eu que tranquei.

- O Tony sempre te mostra onde estão coisas perdidas? (FILGUEIRAS; HENRIQUE; REIS, 2011, vol. 3, p. 78)

Ainda tratando do sistema de pessoa-número, vale mencionar brevemente o caso da forma imperativa, que Britto (2012, p. 99) considera complexo. Segundo ele, emprega-se mais a forma de segunda pessoa do imperativo, como em "pega a bola, Maria", no lugar de "pegue a bola, Maria", mesmo quando no restante do discurso verifica-se a forma de tratamento "você", com os verbos pronomes na terceira pessoa. $\mathrm{Na}$ tradução das alunas da UnB, pode-se verificar a ampla utilização da segunda pessoa. Abaixo, excertos de diálogos do personagem Hallorann (FILGUEIRAS; HENRIQUE; REIS, 2011, p. 61): 
Tabela 4 - Marcas de oralidade em mistura de pessoa-número

\begin{tabular}{cc}
\hline Original & Tradução \\
\hline Keep it clean, that's all I ask. & Deixa tudo limpo, é tudo que peço. \\
\hline "That's right! And you bein a friend, you \\
make it Dick." & - Isso mesmo! E já que cê é um amigo, \\
& me chama de Dick. \\
\hline
\end{tabular}

Fonte: Filgueiras, Henrique e Reis (2011).

No entanto, em contextos em que se deseja conotar mais autoridade na relação com o interlocutor, o falante pode adotar a terceira pessoa do imperativo, em particular quando se tem os verbos "ter", "haver" e "seja". Por exemplo, um adulto dando uma ordem a uma criança diria, "João, tenha modos" ou "Maria, seja educada com a vovó".

Na retradução de The Shining, observa-se o uso do imperativo nas falas que os personagens expressam autoridade. As autoras argumentam que

esse fenômeno ocorreu também quando Jack manda Wendy matar as vespas que estão no quarto de Danny, demonstrando o seu lado autoritário e rude. Assim, "Shut the fuck up and kill them!" foi traduzido como "Cale a boca, porra! Mate as vespas!". (idem, p. 62)

Prossigo para a análise do "uso do pronome do caso reto na posição de objeto", que, de acordo com minha perspectiva, constitui uma marca de oralidade demasiadamente controversa. Afinal, parece-me rotineiro ouvir adultos corrigindo crianças e adolescentes que proferem frases como "eu vi ela", ao invés da canônica "eu a vi”, e qualquer indivíduo mais apegado à correção normativa gramatical estremeceria ao deparar-se com tamanho "erro". Contudo, sabese que língua oral nem sempre acompanha as regras prescritivas e como tenho observado numa impressão meramente a título de ilustração, sem rigor científico - não é nada incomum ouvir as mesmas pessoas que tanto corrigem um "a menina viu ele correndo" dizendo "deixe ele em paz” em vez do, formalíssimo, “deixe-o em paz”.

Britto (2012, p. 100) concorda com o argumento. O pronome reto no lugar do oblíquo é tido como um "erro crasso na escrita, muito embora praticamente todos os falantes de português brasileiro, de qualquer classe social e qualquer nível de instrução, o utilizem cotidianamente". 
No passado, continua, muitos autores condenavam seu uso, mas percebe-se um crescente número de autores brasileiros que não se intimidam em usar um pronome reto como objeto, o que pode amenizar o tabu em volta do fenômeno.

Não obstante, as autoras em questão decidiram ignorar tabus gramaticais e deixaram se levar pelo ouvido ao traduzir os seguintes diálogos (FILGUEIRAS; HENRIQUE; REIS, 2011, p. 137):

Tabela 5 - Marcas de oralidade em uso do pronome reto no lugar do pronome oblíquo

\begin{tabular}{ccc}
\hline Personagem & Original & Tradução \\
\hline Jack & Danny: We call $\underline{\text { him } \text { doc }}$ & Danny, a gente chama ele de velhinho às \\
& sometimes. & vezes. \\
\hline Hallorann & "Let me by " Danny said & Deixa eu passar - Danny disse.
\end{tabular}
Fonte: King (2007) e Filgueiras, Henrique e Reis (2011).

c) formas verbais simplificadas:

Tenho comentado muito a respeito da ausência e presença da oralidade em The Shining e nas versões de sua tradução brasileira. Uma marca que confere um significativo tom de "fala" à escrita, sendo uma opção relativamente segura ao tradutor, isto é, sem risco de provocar um estranhamento excessivo no leitor, é a "adoção de formas sintáticas simplificadas" (BRITTO, 2011). Na versão publicada do autor (BRITTO, 2012, p. 96), encontro a explicação dessas formas no título de "sistema de tempo, modo e aspecto", em que ele enquadra os diferentes tempos e modos verbais. Assim, para se obter o efeito de verossimilhança, é sugerido que se utilize as formas analíticas (“eu estava almoçando quando eles chegaram”) em detrimento do pretérito mais-que-perfeito e do futuro do presente (este costuma ocorrer mais em construções do tipo “será que...?”). Na tradução publicada brasileira deparo-me com a frase "Wendy podia ouvir a máquina de escrever que Jack trouxera lá de baixo" (FILGUEIRAS; HENRIQUE; REIS, 2011, p. 138, grifo meu). Já as autoras empregaram a forma analítica, que resultou em um pouco mais de espontaneidade: "Wendy escutava a máquina de escrever que Jack havia trazido lá de baixo" (idem). Porém, acredito que a forma "tinha trazido" coubesse melhor para os fins das autoras, pois é mais natural aos ouvidos. 
Estou convicta de que ilustrei com exemplos suficientes o que seriam as marcas de oralidade sintáticas num texto traduzido ${ }^{27}$. Filgueiras, Henrique e Reis (2011), elencaram alguns outros traços de oralidade em seu trabalho, assim como Britto (2012), mas preferi me ater apenas nas marcas supracitadas, visto que meu objetivo era contrastar a sua ausência nas primeiras edições de $O$ iluminado em território nacional, o tímido surgimento na revisão de 2009 e a presença calculada na proposta de retradução das universitárias em questão.

Por fim, concluo este capítulo ouvindo a voz de mais dois personagens: Danny e Hallorann. Optei por abordá-los mais ao fim, pois suscitam questões que transcendem a simples marcação da oralidade e abrangem outros problemas. Danny, o mocinho da história, tem apenas cinco anos e está em processo de alfabetização, como visto em "Arrepios na narrativa". Confunde palavras homófonas, dá novos significados às palavras e fica temeroso diante das que ainda não adentraram seu vocabulário (FILGUEIRAS; HENRIQUE; REIS, 2011, p. 47).

Poderia citar os mais variados exemplos, mas fico com aquele que é, provavelmente, o mais marcante de The Shining. Tanto no livro quanto na versão para o cinema (KUBRICK, 1980), a palavra "REDRUM", escrita assim mesmo, em maiúsculas, é colocada em evidência a todo o momento. Danny se depara com ela durante suas visões e insistentemente, questiona aos adultos o que se esconde por trás da estranha combinação de letras. Ninguém lhe responde com certeza o que é "REDRUM", e pode-se dizer que a busca por seu significado - e a vacilação entre uma explicação racional e a sensação medonha que ela carrega, segundo Todorov (1992) - é também o grande mistério da narrativa.

Com o intuito de evitar as consequências que a sua não tradução acarreta (relembrando: a perda do clímax, a obrigação de levar o leitor para "fora" do texto, para as notas de rodapé, correr o risco de o leitor ignorar as notas explicativas etc), a proposta do referido projeto final de graduação é uma tradução que se utiliza da imaginação para criar um termo que traga consigo tantos significados quanto "REDRUM" 28 . Pois os personagens tentam explicar o termo ao garotinho como sendo uma combinação de duas palavras: ora é "red rum" (rum vermelho), ora é "red drum" (tambor vermelho). Pode ser muitas coisas ou pode não ser nada.

\footnotetext{
${ }^{27}$ Cabe mencionar que Britto (2012, p. 106) pondera que "as marcas que apresentamos estão longe de representar a totalidade das maneiras possíveis de se criar um efeito de verossimilhança na tradução (e criação) de diálogos". São sugestões, prossegue ele, colhidas ao longo de sua experiência. Portanto, também não pretendo aqui apresentar uma lista exaustiva de marcas de oralidade, mas sim discutir sua relevância como recurso literário e de tradução. ${ }^{28}$ O termo, se lido ao contrário, torna-se "murder", que é assassinato em português.
} 
A vacilação (TODOROV, 1992) de que tratei no capítulo "Arrepios na narrativa", "estaria perdida para todos os leitores que não entendessem ou tivessem pouca proficiência na língua inglesa" (FILGUEIRAS; HENRIQUE e REIS, 2011, p. 48). Argumentando a favor de uma versão que conseguisse explorar todo o potencial estilístico de "REDRUM", as autoras escreveram:

Se [como na tradução brasileira] inseríssemos uma nota explicativa com a tradução das sugestões de Jack e Edmonds [para a palavra REDRUM], faríamos o leitor interromper a leitura para compreender o trecho, num momento que é fundamental para se manter o terror na narrativa, aspecto que, segundo King na obra Danse Macabre (1983, p. 21) , "é a especulação desagradável que vem a mente" antes de o leitor ser apresentado à natureza do fato . (idem, p. 49)

A sugestão que promoveram passou pelo processo de se

pensar em uma palavra que, quando fosse lida de trás para frente, pudesse ser lida de mais de uma maneira, que estivesse dentro do campo semântico de assassinato ou assassinar, isto é, traduções para "murder", que uma das leituras fosse vermelho ou sangue (como no inglês, "red rum" ou "red drum", que podem lembrar a imagem de sangue) e que não fosse tão extensa ("murder" tem seis letras). (idem)

Depois de elaborarem uma extensa lista com diversas possibilidades, decidiram-se pela palavra "MARROM", que de trás para frente é lida como "MORRAM". A escolha deveu-se ao fato de que a palavra tem seis letras como a original, consegue ser interpretada de mais de uma maneira e está dentro do campo semântico de assassinar. O único requisito não atendido foi a presença dos vocábulos vermelho ou sangue na palavra, mas elas conseguiram uma palavra que "pudesse ser lida como uma cor próxima ao espectro de vermelho" (idem). E para que os leitores não se remetessem automaticamente à cor marrom a cada aparecimento do termo, as autoras separaram-no em duas partes em alguns trechos, sobretudo naqueles em que o menininho questiona seu significado a alguém, "visto que Danny ainda não domina a leitura e pode ter ficado confuso na hora de ler a palavra, pensando que eram duas" (idem). Por conseguinte, os dois trechos abaixo são obtidos (grifo meu): 
Tabela 6 - Recriação de "REDRUM"

\begin{tabular}{|c|c|}
\hline Original & Tradução \\
\hline $\begin{array}{l}\text { "Daddy ... ?" He was almost asleep now. } \\
\text { "What?" } \\
\text { "What's redrum?" } \\
\text { "Red drum? Sounds like something an } \\
\text { Indian might take on the warpath." } \\
\text { Silence. }\end{array}$ & $\begin{array}{l}\text { - Papai...? - Ele estava quase } \\
\text { dormindo agora } \\
-\quad \text { O quê? } \\
-\quad \text { O que que é mar rom? } \\
\text { - Mar bom? Parece expressão } \\
\text { de marinheiro, quando estão navegando. } \\
\text { Silêncio. }\end{array}$ \\
\hline $\begin{array}{l}\text { "But now whenever he comes he shows me } \\
\text { bad things. Awful things. Like in the } \\
\text { bathroom last night. The things he shows } \\
\text { me, they sting me like those wasps stung } \\
\text { me. Only Tony's things sting me up here." } \\
\text { He cocked a finger gravely at his temple, a } \\
\text { small boy unconsciously burlesquing } \\
\text { suicide. } \\
\text { "What things, Danny?" } \\
\text { "I can't remember!" Danny cried out, } \\
\text { agonized. "I'd tell you if I could! It's like I } \\
\text { can't remember because it's so bad I don't } \\
\text { want to remember. All I can remember } \\
\text { when I wake up is REDRUM." } \\
\text { "Red drum or red rum?" } \\
\text { "Rum. " } \\
\text { "What's that, Danny?" } \\
\text { "I don't know." }\end{array}$ & $\begin{array}{l}\text { - As coisas que ele me mostra, elas } \\
\text { me picam igual àquelas vespas me } \\
\text { picaram. Só que as coisas do Tony me } \\
\text { picam bem aqui - ergueu um dedo, com } \\
\text { seriedade, até a têmpora, um garotinho } \\
\text { parodiando, inconsciente, um suicídio. } \\
\text { - Que coisas, Danny? } \\
\text { - Não lembro! - Danny gritou, } \\
\text { agonizado. - Eu te falava se eu lembrasse. } \\
\text { É como se eu não pudesse lembrar porque } \\
\text { é tão ruim que eu não quero lembrar. A } \\
\text { única coisa que consigo lembrar quando } \\
\text { acordo é MAR ROM. } \\
\text { - Bom ou rom? } \\
\text { - Rom. }\end{array}$ \\
\hline
\end{tabular}

Considero que as jovens de fato conseguiram concretizar uma recriação à altura de "REDRUM", que levasse em conta as muitas conotações da palavra, ainda que nem todas fossem capazes de ser mantidas. Dessa maneira, evita-se a interrupção da leitura e o texto flui mais, como se Danny estivesse vendo e ouvindo a palavra no próprio português brasileiro. De certo, pois, que não é uma tradução perfeita, e eu, que também fui autora do projeto em questão, hoje percebo as limitações da eficácia de "MORRAM", como sugestão de tradução para "REDRUM". O problema mais aparente, a despeito de todos os pontos positivos já elencados, é o fato de que a solução das autoras é um termo existente e comum em português brasileiro. Os leitores poderiam se questionar por que Danny não entendia o que a palavra queria dizer, devido a seu aspecto rotineiro. Ponderando esse entrave, acredito que ainda se possa buscar uma nova alternativa para "REDRUM" nas futuras edições de $O$ iluminado, uma que soe 
estranha aos leitores e ainda consiga carregar tantas (ou mais) conotações quanto o termo em inglês.

Cabe ainda mais uma objeção à tradução da palavra. Após décadas da primeira publicação de $O$ iluminado e após sua adaptação cinematográfica ter sido dublada e legendada, em que em ambos os meios de comunicação tenha se mantido a forma "REDRUM", sem qualquer tentativa de tradução, admito a possibilidade de a aceitação do público para uma recriação do termo não ser muito favorável. A última edição traduzida (2012) inclusive ilustra na capa um "REDRUM" ensanguentado, revelando ao leitor uma provável identificação entre a palavra e The Shining. Fosse a história veiculada apenas em livros, sem contar com a existência do filme, talvez a recriação conseguisse ser mais bem vista. Talvez com o passar dos anos, com novos públicos surgindo, seja mais viável propor à editora que se encontre outra solução para a consagrada expressão, uma vez que para a caracterização da narrativa como literatura fantástica seja fundamental a existência da vacilação. E certamente a vacilação experimentada pelos personagens com relação à palavra é crucial para o enriquecimento da narrativa. A versão publicada brasileira é, segundo meu ponto de vista, algo carente dessa qualidade.

No caso dos diálogos de Hallorann, a problemática levantada é outra: o personagem fala em Black English, o dialeto típico de grupos sociais estadunidenses compostos em sua maioria por negros, sendo verificado por todo o país (vide a seção "Outra língua, outros sustos”). King (2007) marca essa variação linguística com marcas fonéticas e sintáticas convencionadas para a escrita que almeja representá-la. O problema é que no Brasil não há uma variação linguística que dê conta em nível nacional do modo de falar próprio de um grupo étnico afro-descendente, no máximo populações de quilombolas, cujo uso é bem limitado geograficamente (BRITTO, 2012, p. 116).

Reside na decisão de marcar ou não a tradução desse dialeto a maior polêmica no tocante a marcas de oralidade na escrita. Por um lado, Britto (2012, p.116) afirma que em suas traduções a perda será inevitável quando há presença de Black English, alegando que tal variante "permanece como um exemplo de intraduzibilidade radical" (idem, p. 117), pois não existe um dialeto afrodescendente comum em âmbito nacional. Por outro lado, Wekker e Wekker (1993, p. 228) argumentam que o objetivo das traduções literárias é instilar sentimentos e reações semelhantes no leitor do texto fonte e do texto traduzido. Uma tradução ideal teria a mesma função na cultura alvo daquela que exerce na cultura fonte, tornando ambos os textos 
“intercambiáveis". Tal se aplicaria também a variações não padrões na língua, sendo o papel do tradutor encontrar um equivalente em sua língua que suscite semelhante resposta nos leitores quanto aos aspectos socioculturais. Consideram que o tradutor deve ao menos tentar utilizar circunstâncias da língua de chegada que favoreçam tal "intercambialidade" (idem, p. 236). Também Azevedo (1998, p. 40) concorda com os autores, recomendando que

se a língua alvo não tem duas variedades não padrões capazes de projetar semelhante contraste, a solução pode ser manipular a língua para refletir pelo menos alguns contrastes presentes no original, de maneira que o leitor reconheça-lhes o significado e plausibilidade.

Destarte, cabe ao tradutor (ou à editora) que se depara com o Black English decidir percorrer o caminho da neutralidade ou da marcação, sabendo que a ausência de marcação dialetal pode acarretar numa perda do contraste entre padrão e não padrão e dos sabores culturais, bem como marcas representando a diferença entre variantes pode resultar num texto estranho ao leitor, se a correspondência com o original não for quase idêntica.

Contudo, é minha opinião que, talvez, no caso do personagem em questão, não acarretaria qualquer prejuízo à narrativa se fosse optado por se neutralizar as marcas de oralidade dialetais em sua fala. Embora Hallorann seja essencial para o desenrolar da trama, o contraste entre sua fala e a dos demais personagens não parece ter peso significativo para um ideal entendimento da obra. Uma solução intermediária entre as propostas de tradução variedade não padrão pode ser o emprego intenso das marcas de oralidade, se for intenção de mostrar que o personagem "fala" de modo desviante da variedade padrão, numa autêntica criação de um dialeto literário (AZEVEDO, 1998, p. 28), que "simula a fala por meio de combinações de algumas características proeminentes, para sugerir uma forma de fala que desvia da considerada padrão".

Acredito que as autoras conseguiram recriar um interessante dialeto literário para Hallorann, que, embora não suscite no leitor a mesma relação sociocultural existente nos falantes dos EUA, consegue mostrar sua diferença com relação aos outros protagonistas. Elas optaram por tentar criar uma oralidade ainda mais marcada em Dick Hallorann (FILGUEIRAS; HENRIQUE; REIS, 2011, p. 72), diferenciando sua fala com o uso da marca fonética "cê", no lugar de "você", o que não ocorre com os outros personagens: "aposto que cê aguenta aquela 
ali, né?" (idem, vol. 3 p. 34). Também utilizaram as outras marcas de oralidade presentes ao longo da tradução e, para o original "Missus Torrance", optam pelo coloquial "Dona Torrance", e não o formal "Senhora Torrance". Quando ele pronuncia alguma palavra diferente do padrão esperado, também se tentou mostrar a divergência na tradução: quando se lê no original "peeneumonia" (em vez de "pneumonia", na recriação pode-se ler "peneumonia" (FILGUEIRAS; HENRIQUE; REIS, 2011, pp. 71 e 73).

Abaixo, selecionei um trecho da fala de Hallorann em que se nota a tentativa de Filgueiras, Henrique e Reis (idem, p. 140) de diferenciar a voz do personagem, mediante o uso de marcas de oralidade e recriação de palavras (no caso de "laaafin", que se tornou "riiindo"):

Três horas depois disso, tô alugando um carro no Aeroporto de Miami e vou tá a caminho da ensolarada St. Pete's, louco pra pôr meu calção de banho e riiiindo pelos cotovelos de qualquer pessoa presa na neve.

Para fins de comparação, o trecho em língua inglesa, grifadas a marcas de oralidade:

Three hours after that, I'm rentin a car at the Miama Airport and on my way to sunny St. Pete's, waiting to get inta my swimtrunks and just laaafin up my sleeve at anybody stuck and caught in the snow

\subsection{Limites e possibilidades: será possível a renovação da tradução?}

Como já comentei antes, as autoras gozaram de grande liberdade para adotar uma estratégia que privilegiasse a recriação da informalidade, obtida pela presença das marcas de oralidade na reescrita. Assim, foi possível apresentar no projeto final de graduação um texto que não contava com restrições de normas editoriais, e as próprias tradutoras foram também revisoras do texto, portanto, os recursos adotados puderam ser concretizados sem maiores percalços ou divergências quanto à estratégia.

Por esse motivo, é que enfatizo que tal tradução não serve como parâmetro para apontar quais estratégias seriam mais viáveis para as metas editorais da editora Objetiva em relação ao 
Iluminado, mas indica um caminho praticável. Porém, considerando as propostas de Britto (2012), o próprio fato de que o tradutor já adotou as marcas de oralidade em suas traduções quando achou necessário e, ao que tudo indica, não foi impedido de fazê-lo (idem, p. 106), e também as alterações estratégicas comentadas na revisão de Fátima Fadel e Héllen Dutra, parece-me que se abriu um caminho propício a traduções que privilegiem a reconstrução de efeitos da oralidade na escrita. No caso de a editora continuar a publicar novas edições, é possível, sim, que o texto seja ainda mais alterado, se for considerado o cenário mais favorável a traduções criativas.

Entretanto, os rumos dessa nova trilha em busca da oralidade na tradução de The Shining são muito complexos de prever. Apenas o tempo dirá quais as estratégias tradutórias mais valorizadas pelo sistema literário brasileiro, se serão as marcas de oralidade marcando presença, como na revisão de 2009 e na proposta de Filgueiras, Henrique e Reis (2011), ou se serão as normas gramaticais guiando os diálogos e monólogos dos personagens, marcando a ausência da oralidade, como na tradução de Albuquerque, que apresenta menos tentativas de criar um dialeto literário, segundo Azevedo (1998). É imprescindível acompanhar as novas edições da obra, se existirem, a fim de compreender como a oralidade se reflete na narrativa traduzida. As inovações no texto pretendidas pelas alunas citadas da Universidade de Brasília, no entanto, revelam-se um exercício de valor que mostra que, se o tradutor mantiver um olhar criativo na reelaboração dos recursos literários, o resultado pode ser uma tradução que reflita com mais intensidade as características do texto de origem do que uma tradução que se paute tão somente pelas regras gramaticais em voga. 


\section{CONCLUSÃo}

Encerra-se, portanto, o percurso pelos misteriosos diálogos e pensamentos que pairaram no ar do hotel Outlook. As falas de Jack, Wendy, Danny e Hallorann deixaram de ser confinadas à língua inglesa e agora ganham sobrevida, "faladas" em português brasileiro. Cada nova revisão, cada nova proposta de retradução torna possível que os acontecimentos fantásticos ocorridos na vida desses personagens transpassem os confins das montanhas de neve do Colorado. E cada análise das vozes dos desafortunados Torrance e do gentil Hallorann permite compreender ainda mais o fantástico e obscuro mundo em que viveram/ vivem.

Conforme minha análise nos capítulos prévios, pode-se inferir que a decisão de uma tradução com marcas mais apagadas ou marcas recriadas não dependerá apenas da escolha individual do tradutor, mas de fatores relacionados ao polissistema literário em que se insere (EVEN-ZOHAR, 1990). Certamente que há espaço para as escolhas pessoais do tradutor, mas quanto mais elas divergirem do esperado para o mercado, mais consequências haverá para a tradução em questão - desde mudanças profundas na revisão até a rejeição da própria tradução por parte do público e da crítica.

As mudanças nas normas (TOURY, 2005) da tradução podem explicar o porquê de também uma tradução ser rejeitada numa época e, muitos anos depois, vir a tornar-se exemplo para novos tradutores. É o caso da tradução de Odorico Mendes Ferreira, que no século XIX recriou palavras em português em sua tradução de épicos gregos. Quando de sua publicação e mesmo muitos anos depois -, recebeu severas críticas relativas à sua tentativa de marcar em na tradução o que era marcado no texto original. O que era marcado eram as chamadas “palavras-valise", verdadeiros agrupamentos de signos que produziam um novo vocábulo, uma técnica de recriação que antecipou as inovações de futuros autores: no século seguinte, Guimarães Rosa tornou-se conhecido pela criação de inúmeros neologismos em sua obra literária - e tradutores do calibre de Antônio Houaiss foram buscar na escrita do mineiro diplomata a inspiração para suas soluções tradutórias (PAES, 1990, p. 15). O mercado editorial tornou-se, por assim dizer, mais aberto a traduções criativas, pelo menos para as traduções de autores consagrados por tradutores reconhecidos.

Hoje pode-se supor que as políticas editoriais para traduções estão mais amadurecidas, o que poderia ser o reflexo não somente do aumento da quantidade de traduções feitas aqui, como também do processo de fortalecimento dos estudos da tradução em solo brasileiro. $\mathrm{O}$ 
acesso dos profissionais envolvidos na feitura de textos traduzidos a uma abordagem teórica mais enriquecida seria capaz de proporcionar terreno sólido para o desenvolvimento de traduções menos padronizadas, isto é, que não tenham por diretriz apenas a gramática normativa para enquadrar o texto, mas que tenham a sua disponibilidade a recriação textual que leve em consideração os aspectos linguísticos da sociedade como um todo, não apenas uma parte dela ${ }^{29}$.

Portanto, creio que a constante republicação da tradução de The Shining e a recente renovação na reescrita dos recursos literários, em 2009, são indicadores de que a obra ocupa uma posição, se não central, ao menos já se encontra mais afastada da periferia do polissistema literário brasileiro, o que permitiria mais liberdade em relação à tradução, uma vez que não há mais a preocupação inicial com a aceitação dos leitores - a obra já está bem estabelecida pelo Brasil. O lançamento de uma edição posterior, em 2012, parece-me um sinal claro da aprovação do público, que, inclusive, aceitou a nova revisão sem qualquer sobressalto, como pude notar ante a uma consulta a sites de busca e nas páginas de comentários dos leitores, nos sites de grandes livrarias brasileiras (vide "Aterrorizando em solo brasileiro").

A proposta das tradutoras Débora Cristina Guedes dos Reis, Maria Stefânia Caldeira Henrique e Nathália Louise Corvello Filgueiras (2011) apresenta-se como uma alternativa mais consciente no tocante à utilização da criatividade na escrita, levando a cabo as sugestões de Britto (2012) para a escrita das marcas de oralidade. Como não era uma publicação editorial mas acadêmica, as jovens puderam exercer diversos experimentos com a linguagem, por meio também de trocadilhos e recriação de palavras inventadas, sem se preocuparem com normas que visassem mais ampla recepção no mercado. A tradução por elas feita pode servir como inspiração para que editoras, sobretudo aquelas especializadas em livros considerados como paraliteratura (SILVA, 2007), não tenham demasiado receio em ousar na tradução, em particular, na tradução de livros carregados em marcas de oralidade. Pois, se a obra na língua de partida suscita no leitor um efeito de informalidade alcançado pela recriação da oralidade, seria interessante que na língua de chegada se tentasse, ao menos, recriar o mesmo efeito. Como diria Britto (2012), traduzir o marcado pelo marcado.

\footnotetext{
${ }^{29}$ Não quero dizer aqui que somente um profissional habilitado num curso de graduação é capaz de produzir uma tradução de texto literário com boa qualidade. Reconheço que há ótimos tradutores brasileiros que jamais frequentaram um curso superior de tradução, entre eles diversos escritores de renome, fato que não interfere na excelência da tradução. Meu ponto, e também opinião pessoal, é que cursos de tradução consolidados constituem um elemento a mais (e não exclusivo) que contribui para elevar a qualidade das traduções no Brasil.
} 
Espero que ao longo desta dissertação, eu tenha sido bem sucedida em demonstrar que uma obra, mesmo que não seja considerada alta literatura, pode se beneficiar de uma tradução criativa com relação aos recursos literários, proporcionando maior riqueza aos elementos textuais na narrativa traduzida. Ao longo dos quase quarenta anos da presença de $O$ iluminado no Brasil, percebeu-se que o texto traduzido modificou-se, sempre encontrando boa receptividade em meio ao público, mesmo com uma revisão mais permissiva quanto à oralidade (e também mais natural ao falante nativo do português brasileiro). Talvez o futuro reserve à obra gratas surpresas para com a tradução de suas características mais marcantes. É minha esperança poder contribuir com as ideias aqui apresentadas para os tradutores incumbidos de verter à língua portuguesa textos repletos de diálogos e marcas de oralidade. Confio que mediante a minha análise e meu cotejo entre texto original e traduzido, possa iluminar o caminho daqueles que se lançarem à saga de traduzir um romance de ficção, em especial, as fantásticas histórias de terror. 


\section{REFERÊNCIAS}

ALKMIN, Tânia Maria. Sociolinguística. In: MUSSALIM, Fernanda; BENTES, Anna Christina. Introdução à linguística: domínios e fronteiras. 2. Ed. São Paulo: Cortez, 2001.

AZEVEDO, Milton. Orality in Translation: Literary Dialect from English into Spanish and Catalan. Sintagma, v. 10, 1998. Disponível em: $<$ http://scholar.google.com.br/scholar_url?hl=pt-

PT\&q=http://dialnet.unirioja.es/descarga/articulo/128900.pdf\&sa=X\&scisig=AAGBfm14BC ANiQmjfS69GZWRaepzBECvCA\&oi=scholarr\&ei=3sRXUoBeh7r1BOGdgJAH\&ved=0CC oQgAMoADAA. Acesso em: mai. 2014.

BAGNO, Marcos. A língua de Eulália: novela sociolinguística. São Paulo: Contexto, 2006.

BAGNO, Marcos. Preconceito linguístico: o que é, como se faz. São Paulo: Loyola, 2002.

BARRENTO, João. Palimpsestos imperfeitos (que significa traduzir o cânone?). In: LEAL, Isabela; GUIMARÃES, Mayara; COSTA, Walter Caros (org.). No horizonte do provisório: ensaios sobre tradução. Rio de Janeiro: 7 Letras. pp. 11 a 24.

BENJAMIN, Walter. A tarefa do tradutor: quatro traduções para o português. Belo Horizonte: Fale/ UFMG, 2008. pp. 88 a 98.

BERMAN, Antoine. A prova do estrangeiro: a tradução em manifesto. Bauru: EDUSC, 2002.

BLOOM, Harold. O cânone ocidental. Rio de Janeiro: Objetiva, 1993.

BRITTO, Paulo Henriques Britto. A tradução literária. Rio de Janeiro: Civilização Brasileira, 2012.

CALVET, L. Jean. Sociolinguística: uma introdução crítica. Tradução Marcos Marcionilo. São Paulo: Parábola, 2002.

CÂNDIDO, Antônio. Formação da Literatura Brasileira. Belo Horizonte/ Rio de Janeiro: Itatiaia, 1997.

EVEN-ZOHAR, Itamar. Polysystem Studies. Poetics Today, 1990.

FRANÇA, Júlio. O horror na ficção literária: reflexão sobre o "horrível" como categoria estética. In: CONGRESSO INTERNACIONAL DA ASSOCIAÇÃO BRASILEIRA DE LITERATURA COMPARADA: TESSITURAS, INTERAÇÕES, CONVERGÊNCIAS, 11 ., 2008, São Paulo. Anais do XI Congresso Internacional da Associação Brasileira de Literatura Comparada. São Paulo: ABRALIC, 2008. Disponível em:

http://www.abralic.org.br/anais/cong2008/AnaisOnline/simposios/pdf/077/JULIO_FRANCA. pdf Acesso em: set. 2011.

FILGUEIRAS, L. C. Nathália; HENRIQUE, C. Maria Stefânia; REIS, C. G. Deborah. Traduzindo The Shining: uma realidade assustadora. Projeto Final (Letras - Tradução Inglês). Universidade de Brasília, 2011.

GONÇALVES, Vansan. O medo e o terror psicológico em "O iluminado", de Stephen King. Abr. 2012. Disponível em: 
https://sobreomedo,wordpress.com/?s=Gon\%C3\%A7alves\&submit=Procurar Acesso em jan. 2016.

KING, Stephen. Danse Macabre. Estados Unidos: Berkley Books, 1983.

KING, Stephen. The Shining. Londres: Hoddler, 2007.

KING, Stephen. O Iluminado. Tradução: Betty Ramos de Albuquerque. Rio de Janeiro: Record, 1977.

KING, Stephen. O Iluminado. Tradução: Betty Ramos de Albuquerque. Rio de Janeiro: Objetiva, 1999.

KING, Stephen. O Iluminado. Tradução: Betty Ramos de Albuquerque. Rio de Janeiro: Objetiva, 2005.

KING, Stephen. O Iluminado. Tradução: Betty Ramos de Albuquerque. Rio de Janeiro: Objetiva, 2009.

KING, Stephen. O Iluminado. Tradução: Betty Ramos de Albuquerque. Rio de Janeiro: Suma de Letras, 2012.

KOHAN, Silvia Adele. Como escrever diálogos: a arte de desenvolver o diálogo no romance e no conto. Belo Horizonte: Gutenberg. 2013

LYONS, John. Linguagem e linguística: uma introdução. Rio de Janeiro: LTC, 1987. pp. 3435 .

LIVY. Resenha: O iluminado de Stephen King - Editora Suma de Letras. Jan. 2013. Disponível em: www.nomundodoslivros.com/2013/01/resenha-o-iluminado-de-stephen-king.html Acesso em jan. 2016.

MCDOWELL, Edwin. Behind the Best Sellers. The New York Times. Set. 1981. Disponível em: 〈http://www.nytimes.com/books/97/03/09/lifetimes/kin-v-behindbest.html〉 Acesso em jun. 2014.

MILTON, John. The importance of economic factors in translation publication. In: Beyond Descriptive Translation Studies. Amsterdã- Filadélfia: John Benjamins, 1995.

O iluminado. Avaliação dos consumidores. Livraria Cultura. www.livrariacultura.com.br/p/oiluminado-30369249\#costumers-reviews Acesso em jan. 2016.

O iluminado. Saraiva. Avaliação geral. Disponível em: <www.saraiva.com.br/o-iluminado4266309.html\#go-review-list> Acesso em jan. 2016.

PAES, José Paulo Paes. Tradução: a ponte necessária. São Paulo: Ática, 1990.

REISS, Katharina. Translation Criticism: The Potentials \& Limitations. Grã-Bretanha: St. Jerome Publishing, 2000. pp. 31-38.

RICKFORD, John. African American English. Londres: Routledge, 1998.

RICKFORD, John. Spoken Soul: The Story of Black English. Nova York: John Wiley, 2000. 
RICKFORD, John. African American Vernacular English: Features and use, Evolution and Educational Implications. Londres: Blackwell, 1999.

TODOROV, Tzvetan. Introdução à Literatura Fantástica. São Paulo: Perspectiva, 1992.

TOURY, Gideon. The Nature and Role of Norms in Translation. In: Descriptive Translation Studies and Beyond. Amsterdã- Filadélfia: John Benjamins, 1995.

SILVA, Vítor Manuel Aguiar. Teoria da literatura. Coimbra: Almedina, 2007.

VIEIRA, Elisa Ribeiro Pires. Contextualizando a tradução: introdução. UFMG, 1996.

WEKKER, Gloria; WEKKER Herman. Coming in from the cold: Linguistic and sociocultural aspects of the translation of black English vernacular literary texts into Surinamese Dutch. International Journal of Translation. Babel, 1993. 


\section{ANEXO I - EXCERTO DA TRADUÇÃO DE THE SHINING}

Selecionei o trecho abaixo da tradução realizada no trabalho de conclusão de curso que produzi juntamente com Débora C. G. dos Reis e Maria Stefânia Caldeira Henrique (FILGUEIRAS; HENRIQUE; REIS, 2011). Passados alguns anos, percebo que poderiam ser elaboradas diversas melhorias na tradução. Não obstante, acredito ser interessante evidenciar aqui uma parte da tradução do projeto em questão, a fim de ilustrar esta dissertação, em especial os aspectos referentes à oralidade, que podem ser encontrados aqui com abundância.

\section{Capítulo 11}

Havia quatro bagagens empilhadas logo do lado de fora da porta. Três delas eram malas antigas, gigantes e surradas, cobertas de um couro preto que imitava pele de jacaré. A última era uma mochila, deveras grande, de zíper e tecido tartan desbotado.

— Aposto que cê aguenta aquela ali, né? - perguntou-lhe Hallorann. Ele pegou as duas malas maiores com uma mão e ergueu a outra sob o braço.

- Claro - disse Danny. Ele agarrou a mala com as duas mãos e desceu, com o cozinheiro, até os degraus da varanda, tentando, como um homenzinho, não grunhir e transparecer o tanto que estava pesada.

Um vento agudo e cortante soprava desde o momento em que chegaram; assobiava pelo estacionamento, fazendo com que Danny semicerrasse os olhos enquanto carregava a mochila de zíper à frente, batendo em seus joelhos. Umas poucas folhas errantes de álamo farfalharam e se moveram em direção ao asfalto, ora praticamente deserto, fazendo com que Danny pensasse por um momento naquela noite da semana passada quando acordou do pesadelo e escutou - ou pensou que escutou - Tony falando para que ele não fosse.

Hallorann deixou a bagagem perto do porta-malas de um Plymouth Fury bege.

— Esse não é um carro de verdade - confidenciou a Danny — é só alugado. A minha Bessie é outra coisa. Ela, sim, é um carro. Cadillac 1950, e se ela corre macia? Eu falo pra todo mundo. Ela fica na Flórida porque é muito velha pra toda essa escalada nas montanhas. Precisa de ajuda aí?"

— Não, senhor — disse Danny. O menino conseguiu carregar a mala nos últimos dez ou doze degraus sem grunhir e foi com um grande suspiro de alívio que a pôs no chão.

- Bom menino - disse Hallorann. Tirou um grande chaveiro do bolso de sua jaqueta de sarja azul e destrancou o porta-malas. Enquanto colocava as bagagens no carro, falou:

- Você tem uma iluminação, garoto. Mais forte do que de qualquer outra pessoa que conheci na minha vida. E olha que já vou fazer sessenta anos nesse mês de janeiro. 
- Você tem um dom - disse Hallorann, virando-se para Danny. — Eu, bom, sempre chamei isso de iluminação. É como a minha vó chamava, também. E ela era iluminada. A gente costumava se sentar na cozinha quando eu era um garoto não muito mais velho do que você e a gente conversava bastante sem nem abrir a boca.

- É mesmo?

Halloran sorriu ante a expressão boquiaberta, quase faminta de Danny e disse

— Vem cá e senta no carro por uns minutos. Quero falar com você.

Fechou o porta-malas.

No saguão do Overlook, Wendy Torrance viu seu filho sentar-se no banco do passageiro do carro de Hallorann ao mesmo tempo que o grande cozinheiro negro entrou atrás do volante. Uma brusca ânsia de medo atingiu-a e ela abriu os lábios para dizer a Jack que Hallorann não estava brincando quando disse que levaria Danny para Flórida - era um sequestro em andamento -; porém os dois só estavam sentados. Ela mal podia ver a pequena silhueta da cabeça do filho, voltada, atentamente, para a grande, de Hallorann. Até mesmo a essa distância aquela cabecinha tinha algo que ela reconhecia - era a maneira como seu filho olhava quando havia algo na TV que lhe exercia um fascínio particular ou quando ele e o pai jogavam "mico" ou aquele "cribbage" idiota. Jack, que ainda procurava Ullman, ainda não percebera. Wendy manteve silêncio, observando o carro de Hallorann com nervosismo, imaginando qual seria a conversa que fazia Danny levantar a cabeça daquele jeito.

No carro, Halloran dizia:

— Se sentiu meio que sozinho, pensando que era o único?

Danny, que tanto se sentia com medo quanto sozinho, fez que sim.

— Sou o único que você já encontrou? — perguntou.

Hallorann riu e balançou a cabeça.

— Não, criança, não. Mas você é o mais iluminado.

— Então tem muitos?

- Não - disse Hallorann - mas sua iluminação é mais forte do que a dos outros. Muita gente, eles têm um pouco de luz neles. E nem sabem. Mas eles sempre aparecem com flores quando as esposas estão se sentindo meio pra baixo naqueles dias, se dão bem nas provas da escola sem nem estudar, conseguem ter uma boa noção de como as pessoas estão se sentindo assim que entram numa sala. Já encontrei uns cinquenta ou sessenta desse jeito. Mas acho que só uns doze, contando a minha vó, que sabiam que eram iluminados.

— Uau! — disse Danny e refletiu a respeito. Então — Você conhece a Sra. Brant? 
— Ela? - Halloran perguntou com desdém. — Ela não é iluminada. Manda o jantar de volta umas duas ou três vezes toda noite.

— Eu sei que ela não é — disse Danny sério. — Mas sabe o homem de uniforme cinza que pega os carros?

— O Mike? Claro, conheço o Mike. O que é que tem ele?

— Sr. Halloran, por que ela queria a calça dele?

— Do que cê tá falando, garoto?

- Bom, enquanto ela olhava pra ele, ela pensava que com certeza queria se enfiar dentro da calça dele e fiquei pensando porque...

Ele, porém, não prosseguiu. Hallorann jogou a cabeça para trás e soltou do peito uma sonora e misteriosa gargalhada, que ressoou no carro como um tiro de canhão e fez o assento tremer, tamanha a força. Danny sorriu, confuso, e, por fim, o trovão deu lugar a risadas entrecortadas. Hallorann retirou um grande lenço de seda do bolso da camisa como se levantasse uma bandeira de rendição e enxugou as lágrimas dos olhos.

— Garoto, - ele disse, ainda um pouco resfolegante — cê vai aprender tudo o que tem que saber sobre a condição humana antes de completar dez anos. Não sei se fico ou não fíco com inveja de você.

- Mas a Sra. Brant...

— Não liga pra ela, não — disse. — E nem vai perguntar pra sua mãe. Ela só ia ficar chateada contigo, saca o que quero dizer?

— Entendo, senhor - respondeu Danny. Ele sacava perfeitamente bem. Ele já havia chateado a mãe assim outra vez.

- Aquela Sra. Brant não passa de uma velha sem-vergonha cheia de vontade, é tudo o que cê precisa saber - ele olhou para Danny intrigado. - Até onde cê consegue chegar, velhinho?

- Hã?

— Me dá um show, vai. Pensa em mim. Quero saber se cê vai tão longe quanto acho que vai.

— No que você quer que eu pense?

— Qualquer coisa. Só pensa com força.

— Tá bom - disse Danny. Ponderou por um momento, depois reuniu toda sua concentração e a dirigiu para Hallorann. Nunca fizera nada exatamente assim antes e, no último instante, alguma parte instintiva dele emergiu e moderou um pouco da força bruta do pensamento; ele não queria machucar o Sr. Halloran. Contudo, o pensamento disparou de dentro 
dele com uma força que ele nunca acreditaria. Era como uma bola rápida de Nolan Rylan com uma forcinha extra.

(Nossa, espero que não machuque)

E o pensamento foi:

\section{(!!! OI, DICK!!!)}

Hallorann estremeceu e deu um solavanco para trás no assento. Seus dentes se juntaram com um estalo, de maneira que escorreu sangue do lábio inferior numa fina gota. Suas mãos se levantaram do colo involuntariamente até a altura do peito e depois repousaram, de novo. Por um momento, suas pálpebras tremularam débeis, sem controle consciente, e Danny assustouse.

— Sr. Hallorann? Dick? Tá tudo bem?

- Não sei - disse Hallorann e deu uma risada fraca. - Juro por Deus que não sei. Meu Pai, garoto, você é uma arma.

- Desculpa - replicou Danny, mais alarmado. - É melhor eu chamar o papai? Vou correndo chamar.

— Não, aqui estou eu. Tô bem, Danny. Pode ficar sentado aí. Me sinto meio remexido, nada de demais. na última hora.

— Não fui com toda a força que eu podia - confessou o menino. - Fiquei com medo,

— É capaz, sorte minha que você ficou ... Meus miolos iam sair pelas orelhas.

Ele viu a expressão de alarme em Danny e sorriu.

— Não me machucou. Como você se sentiu?

— Igual o Nolan Ryan jogando uma bola rápida — replicou logo.

— Gosta de beisebol, né? — Hallorann massageava as têmporas com cuidado.

- O papai e eu gostamos do Angels - contou Danny. - Do Red Sox, na divisão Leste da Liga Americana e do Angels, na divisão do Oeste. A gente foi ver o Red Sox contra Cincinnati na Série Mundial. Eu era mais pequeno na época. E o Papai era... - o semblante de Danny tornou-se lúgubre e preocupado.

- O que foi, Dan?

- Esqueci - disse Danny. Começou a colocar o polegar na boca para chupá-lo, mas aquilo era coisa de bebê. Colocou a mão de volta ao colo. 
— Consegue saber o que sua mãe e seu pai tão pensando, Danny? - Hallorann o observava de perto.

- Quase sempre, se eu quiser. Mas eu quase nunca tento.

— Por que não?

- Bom... - ele pausou por um momento, confuso. - Porque é como ficar espiando o quarto e ver eles fazendo aquilo que faz os bebês. Você sabe o que que é?

— Já tive familiaridade com aquilo — disse Hallorann, sério.

- Eles não iam gostar disso. E eles não iam gostar que eu espiasse o que eles pensam. Ia ser jogar sujo.

- Entendo.

- Mas eu sei como eles se sentem - disse Danny. - Não tenho como não saber. Também sei o que você tá sentindo. Eu te machuquei. Desculpa.

—É só uma dor de cabeça. Já tive ressacas piores. Consegue ler outras pessoas, Danny?

- Ainda não consigo ler direito — respondeu — só poucas palavras. Mas o Papai vai me ensinar a ler nesse inverno. Meu papai ensinava a ler e a escrever numa escola grande. Mais escrever, mas ele também sabe ler.

— Quero dizer, cê consegue saber o que qualquer pessoa está pensando?

Danny refletiu.

- Eu consigo se for alto - disse, por fim. - Como a Sra. Brant e as calças. Ou que nem uma vez, quando eu e a Mamãe, a gente tava numa loja grande pra comprar sapato pra mim, tinha uma criança grande olhando os rádios e ele pensou em levar um sem pagar. Aí ele pensou, "e se eu for preso"? E depois pensou, "como eu quero um desses". Aí ele pensou de novo em ser preso. Ele tava se sentindo mal com isso e ele tava me fazendo mal. A Mamãe tava falando com o homem que vende os sapatos, então eu fui e falei, "menino, não pega o rádio. Vai embora". E ele ficou com medo de verdade. Ele saiu correndo.

Hallorann sorria de orelha a orelha.

- Não duvido nada. Consegue fazer mais alguma coisa, Danny? São só pensamentos e sensações, ou tem mais?

Com cautela:

— Tem mais pra você?

— Às vezes - disse Hallorann. - Nem sempre. Às vezes... Às vezes tenho sonhos. Você sonha, Danny? 
- Têm vezes - Danny disse - que eu sonho acordado. Depois que o Tony aparece seu polegar queria voltar para a boca mais uma vez. Ele nunca contou para ninguém sobre o Tony, só para a Mamãe e o Papai. Fez com que a mão que chupava o polegar voltasse para o colo.

\section{— Quem é Tony?}

$\mathrm{E}$, de repente, Danny teve um daqueles momentos de compreensão súbita que o assustavam mais do que tudo; era como um vislumbre repentino de alguma máquina incompreensível que pode ser tanto segura quanto perigosa e mortal. Ele era muito novo para saber qual das duas opções. Era muito novo para entender.

— O que tem de errado? - exclamou. — Você me perguntou isso tudo porque você tá preocupado, né? Por que você tá preocupado comigo? Por que você tá preocupado com a gente?

Hallorann pôs suas grandes mãos escuras nos ombros do garotinho.

- Para! - disse. - É capaz de não ser nada. Mas se for... Bom, cê tem uma coisa importante na sua cabeça, Danny. Cê precisa crescer um bocado antes de conseguir lidar com isso, eu acho. Cê tem que ser corajoso.

- Mas eu não entendo as coisas! - Danny irrompeu. - Eu sei, mas não sei! As pessoas... Elas sentem coisas e eu sinto as mesmas coisas, mas eu não sei o que eu tô sentindo! Ele olhou para o colo com tristeza. nenhuma.

— Eu queria saber ler. Às vezes o Tony me mostra placas e não consigo ler quase

—Quem é Tony? - Hallorann perguntou mais uma vez.

- A Mamãe e o Papai falam que o Tony é meu "amigo invisível" - disse Danny, recitando as palavras com cuidado. - Mas ele é real. Pelo menos, eu acho que é. Às vezes, quando eu tento pensar com força nas coisas, ele vem. Ele fala, "Danny, quero te mostrar uma coisa". E parece que eu desmaio. É só que... têm uns sonhos, como você falou - ele olhou para Hallorann e conteve-se. - Antes eles eram bons. Mas agora... Eu não consigo lembrar a palavra para os sonhos que dão medo e fazem a gente chorar.

— Pesadelos? — perguntou Hallorann.

— É. É isso. Pesadelos.

— Com esse lugar? Com o Ovelook?

Danny olhou de novo para a mão do polegar que chupava. Hallorann:

— Sim — ele sussurrou. Em seguida, disse em tom estridente, olhando para o rosto de 
- Mas eu não posso contar pro papai e nem você pode! Ele precisa desse emprego porque é o único que o Tio Al conseguiu pra ele e ele precisa terminar a peça, senão ele vai começar a fazer a Coisa Feia de novo e eu sei o que isso é, é ficar bêbado, é isso que é, é quando ele sempre ficava bêbado e aquilo era fazer uma Coisa Feia! - o menino parou, à beira de lágrimas.

- Shh — disse Hallorann e levou o rosto de Danny contra a sarja áspera de sua jaqueta. Ela tinha cheiro de naftalina. - Tá tudo bem, filho. E se seu dedão gosta da sua boca, deixa ele ir pra onde ele quiser — mas em seu rosto havia preocupação.

Ele disse:

- O que você tem, filho, eu chamo de ser iluminado, a Bíblia chama de ter visões e têm cientistas que chamam de precognição. Já li sobre isso, filho. Já estudei sobre isso. Todos eles significam ver o futuro. Entende?

Danny fez que sim, contra a jaqueta de Hallorann.

— Lembro da iluminação mais forte que eu já tive assim... Nunca vou esquecer. Era 1955. Ainda tava no Exército, na época, servindo no estrangeiro, na Alemanha Ocidental. Era uma hora antes da janta e eu tava no tanque, dando uma bronca num soldado que tava tirando boa parte da batata junto com a casca. E eu falo, "Aqui, deixa eu mostrar como é que se faz". Ele me entregou a batata e o descascador e depois toda a cozinha sumiu. Bum, desse jeito. Cê disse que vê esse cara, o Tony, antes... antes de sonhar?

\section{Danny confirmou.}

Hallorann pôs um braço em torno do menino. "Comigo é cheiro de laranja. Toda aquela tarde eu fiquei sentindo cheiro de laranja e sem me preocupar, porque elas tavam no cardápio da noite - a gente tinha trinta engradados de laranja Valência. Todo o pessoal da droga daquela cozinha tava sentindo cheiro de laranja naquela noite.

- Por um segundo pensei que tinha desmaiado. Aí, depois, ouvi uma explosão e vi umas chamas. Tinha gente gritando. Sirenes. E ouvi esse barulho assobiante que só podia ser de vapor. Depois parecia que eu cheguei mais perto do sei lá o que era aquilo e vi um vagão fora dos trilhos e caído de lado, escrito Estrada de Ferro Geórgia e Carolina do Sul nele e eu soube, como um relâmpago, que meu irmão Carl tava naquele trem e ele saiu do trilho e Carl tinha morrido. Desse jeito. E então desapareceu e aquele cozinheirinho medroso e tapado na minha frente, ainda segurando a batata e o descascador. Ele diz, "tá bem, Sargento?” E eu digo, "Não. Meu irmão acabou de morrer lá na Geórgia". E quando finalmente consegui falar com a mãe no telefone internacional, ela me disse como aconteceu.

— Mas, olha só, garoto, eu já sabia como tinha sido.

Ele balançou a cabeça devagar, como se despedindo da lembrança, e olhou para o menino de olhos arregalados.

- Mas a coisa que cê tem que lembrar, meu garoto, é isso aqui: essas coisas nem sempre acontecem de verdade. Lembro que há quatro anos eu trabalhava como cozinheiro num 
acampamento de meninos lá no Maine, em Long Lake. Então eu tava sentado no portão de embarque no Aeroporto de Logan, em Boston, esperando meu voo e comecei a sentir cheiro de laranja. Pela primeira vez em, acho que, uns cinco anos. Aí falei pra mim mesmo, "Meu Deus, o que será que vem agora nesse show louco?" e fui pro banheiro e sentei num dos boxes para ter privacidade. Eu não desmaiei, mas comecei a ter essa sensação cada vez mais forte de que meu avião ia cair. Depois a sensação passou, e o cheiro de laranjas também, e eu sabia que tinha acabado. Voltei pro balcão das Linhas Aéreas Delta e mudei meu voo para umas três horas mais tarde. E sabe o que aconteceu?

\section{— O quê? — Danny murmurou.}

- Nada! - disse Hallorann e riu. Também estava aliviado de ver o menino sorrir um pouco. - Nadica de nada! O velho avião aterrissou bem na hora e sem nem um solavanco nem um arranhão. Aí você vê... Às vezes essas sensações não dão em nada.

\section{- Ah - disse Danny}

- Ou que nem quando vai apostar nos cavalos. Eu aposto bastante e geralmente vou muito bem. Eu fico perto da pista quando eles vão pro portão de largada, e às vezes tenho um pouco de iluminação nesse ou naquele cavalo. Em geral, essas sensações me ajudam a ficar bem de verdade. Sempre digo que um dia vou ganhar, de uma vez, três apostas em três azarões e fazer bastante na trifeta pra me aposentar cedo. Ainda não aconteceu. Mas eu vivo voltando pra casa nas minhas próprias "patas", em vez de voltar num táxi, com minha carteira recheada. Ninguém é iluminado o tempo todo, com exceção de Deus lá no céu.

- Sim, senhor - disse Danny, pensando na época de quase um ano atrás quando Tony lhe mostrou um novo bebê deitado num berço na casa deles em Stovington. Ele ficou muito empolgado com a notícia e esperou, sabendo que levava tempo, mas não houve nenhum bebê.

- Agora cê escuta - disse Hallorann e tomou as mãos de Danny nas suas. - Eu já tive uns sonhos ruins aqui e tive sensações ruins. Já trabalhei aqui por duas temporadas e acho que uma dúzia de vezes eu tive... bom, pesadelos. E acho que uma meia dúzia de vezes eu pensei ter visto coisas. Não, não vou dizer o quê. Não é pra um garotinho como você. Só coisas horríveis. Uma vez teve a ver com aquelas malditas cercas vivas podadas que nem bichos. Noutra vez tinha uma moça, Delores Vickery era o nome dela, e ela tinha um pouquinho de iluminação nela, mas eu não acho que ela sabia. O Sr. Ullman demitiu ela... Sabe o que é isso, velhinho?

- Sei, senhor, - disse Danny com franqueza - meu pai foi demitido do trabalho de professor e é por isso que a gente tá no Colorado, eu acho.

- Bom, o Ullman demitiu a moça porque ela tava dizendo ter visto alguma coisa num dos quartos onde... bom, onde uma coisa ruim aconteceu. Foi no quarto 217, e quero que cê me prometa que não vai lá, Danny. Em todo o inverno. Fica bem longe de lá.

— Tá bom — disse Danny. - A senhorita, a moça, ela te pediu pra dar uma olhada?

- Pediu sim. E tinha uma coisa ruim lá. Mas... Eu não acho que era uma coisa ruim que pudesse machucar alguém, Danny, é o que tô tentando te falar. As pessoas que são iluminadas às vezes podem ver coisas que ainda vão acontecer, e acho que de vez em quando elas podem 
ver coisas que já aconteceram. Mas são só figuras num livro. Cê já viu uma figura num livro que te deu medo, Danny?

- Já - respondeu, pensando na história do Barba Azul e na figura em que a nova esposa do Barba Azul abre a porta e vê todas as cabeças.

— Mas cê sabia que não podia te machucar, sabia?

— Sa... bia. - disse, um pouco em dúvida.

- Bom, é desse jeito no hotel. Não sei o porquê, mas parece que todas as coisas ruins que aconteceram por aqui, tem pedacinhos dessas coisas que ainda estão por aí como pedaços de unha ou meleca que algum porco grudou debaixo duma cadeira. Não sei por que tem que ser justo aqui, acontece coisa ruim em quase todo hotel do mundo, eu acho, e eu já trabalhei em um monte e nunca tive problema. Só aqui. Mas Danny, eu não acho que essas coisas podem machucar alguém - ele frisou cada palavra na frase com um leve chacoalhar nos ombros do menino. - Então se acontecer de cê ver alguma coisa, num corredor ou quarto ou do lado de fora, naquelas cercas viva... olha pra outro lado e quando cê olhar de novo, já vai ter sumido. Entende o quero dizer?

- Entendo - disse Danny. Ele se sentia muito melhor, confortado. Ajoelhou-se, deu um beijo na bochecha de Hallorann e deu-lhe um grande abraço apertado. Hallorann devolveu o abraço.

— Seus velhos, eles não têm a iluminação, né?

— Não, acho que não.

- Eu testei os dois como fiz com você - Hallorann disse. - Sua mamãe teve um pequeno sobressalto. Eu acho que todas as mães são um pouco iluminadas, sabe, pelo menos até os filhos crescerem o bastante pra se cuidarem sozinhos. Seu pai...

Hallorann pausou por um momento. Ele testara o pai da criança e simplesmente não sabia. Não era como se encontrasse alguém que tivesse a iluminação, ou alguém que com certeza não tinha. Remexer o pai do Danny havia sido... estranho, como se Jack Torrance apresentasse algo, algo que escondia. Ou algo que guardava num local tão profundo e suprimido que era impossível de se alcançar.

— Eu não acho que ele seja iluminado - concluiu Hallorann. - Então não se preocupa com eles. Basta cuidar de você mesmo. Não acho que tenha nada aqui que pode te machucar. Então fica frio, beleza?

- Tá.

— Danny! Ei, velhinho!

— Danny olhou ao redor. — É a Mamãe. Ela tá me chamando. Tenho que ir.

— Eu sei — disse Hallorann. - Que você passe bons dias aqui, Danny. O quanto for possível, de qualquer forma. 
— Certo. Obrigado, Sr. Hallorann. Me sinto bem melhor.

Um pensamento feliz passou por sua mente:

(Dick, pros meus amigos) (Tá bom, Dick)

Os olhos dos dois se encontraram e Dick Hallorann deu uma piscada.

Danny se arrastou pelo assento do carro e abriu a porta do lado do passageiro. Enquanto saía, Hallorann disse:

- Danny?

- O que foi?

- Se tiver problema... dá uma chamada. Um gritão alto igual àquele que cê me nocauteou há alguns minutos atrás. Pode ser que eu te escute mesmo lá na Flórida. E se escutar, venho correndo.

— Tá — disse Danny e sorriu.

- Se cuida, garotão.

— Tá bom.

Danny bateu a porta e saiu correndo pelo estacionamento em direção à varanda, onde estava Wendy, segurando os cotovelos contra o vento friozinho. Hallorann observava, o grande sorriso esmorecendo devagar.

Não acho que tenha nada aqui que pode te machucar.

Não acho.

Mas e se estivesse errado? Ele sabia que essa era a última temporada dele no Overlook desde quando viu aquela coisa na banheira do Quarto 217. Foi pior do que qualquer figura de qualquer livro, e daqui o garoto correndo para a mãe parecia tão pequeno...

Não acho -

Seus olhos vaguearam na direção dos animais da topiaria.

Com brusquidão, deu partida no carro, engatou a primeira e foi embora, tentando não olhar para trás. E é claro que olhou, e é claro que a varanda estava vazio. Eles haviam entrado. Era como se o Overlook os engolisse. 